Camila Fernandes Nascimento

\title{
PAPEL DE PEPTÍDEOS BIOATIVOS DA LAMININA NA ATIVIDADE DOS INVADOPÓDIOS EM LINHAGEM CELULAR DERIVADA DE CARCINOMA ADENÓIDE CÍSTICO
}

Dissertação apresentada ao Programa de Pós-Graduação em Biologia Celular e Tecidual do Instituto de Ciências Biomédicas da Universidade de São Paulo, para obtenção do Título de Mestre em Ciências.

São Paulo 
Camila Fernandes Nascimento

PAPEL DE PEPTÍDEOS BIOATIVOS DA LAMININA NA ATIVIDADE DOS INVADOPÓDIOS EM LINHAGEM CELULAR DERIVADA DE CARCINOMA ADENÓIDE CÍSTICO

Dissertação apresentada ao Programa de Pós-Graduação em Biologia Celular e Tecidual do Instituto de Ciências Biomédicas da Universidade de São Paulo, para obtenção do Título de Mestre em Ciências.

Área de concentração: Biologia Celular e Tecidual

Orientador: Prof. Dr. Ruy Gastaldoni Jaeger

Versão Original

São Paulo

2011 
DADOS DE CATALOGAÇÃO NA PUBLICAÇÃO (CIP)

Serviço de Biblioteca e Informação Biomédica do

Instituto de Ciências Biomédicas da Universidade de São Paulo

(C) reprodução total

Nascimento, Camila Fernandes.

Papel de peptídeos bioativos da laminina na atividade dos invadopódios em linhagem celular derivada de carcinoma adenóide cístico / Camila Fernandes Nascimento. -- São Paulo, 2011.

Orientador: Ruy Gastaldoni Jaeger.

Dissertação (Mestrado) - Universidade de São Paulo. Instituto de Ciências Biomédicas. Departamento de Biologia Celular e do Desenvolvimento. Área de concentração: Biologia Celular e Tecidual. Linha de pesquisa: Biologia tumoral.

Versão do título para o inglês: Role of laminin-111 derived peptides in invadopodia activity of a human adenoid cystic carcinoma cell line.

Descritores: 1. Carcinoma adenóide cístico 2. Laminina 3. Invadopódio I. Jaeger, Ruy Gastaldoni II. Universidade de São Paulo. Instituto de Ciências Biomédicas. Programa de Pós-Graduação em Biologia Celular e Tecidual III. Título. 
Candidato(a): $\quad$ Camila Fernandes Nascimento.

Título da Dissertação: $\quad$ Papel de peptídeos bioativos da laminina na atividade dos invadopódios em linhagem celular derivada de carcinoma adenóide cístico.

Orientador(a): $\quad$ Ruy Gastaldoni Jaeger.

A Comissão Julgadora dos trabalhos de Defesa da Dissertação de Mestrado, em sessão pública realizada a .....................
( ) Aprovado(a)
( ) Reprovado(a)

Examinador(a): Assinatura:

Nome:

Instituição:

Examinador(a): Assinatura:

Nome:

Instituição:

Presidente: Assinatura:

Nome:

Instituição: 


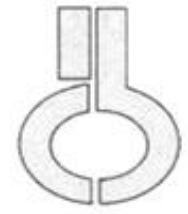

\section{CERTIFICADO DE ISENÇÃO}

Certificamos que o Protocolo CEP-ICB N ${ }^{\circ} 420 / 20$ referente ao projeto intitulado: "Papel de peptídeos bioativos da laminina na atividade dos invadopódios em linbagem celular derivada de carcinoma adenóide cístico" sob a responsabilidade de Camila Fernandes Nascimento, foi analisado na presente data pela CEUA - COMISSÃO DE ÉtICA NO USO DE ANIMAIS e pela CEPSH- COMISSÃo dE ÉtICA EM PESQUiSA COM SERES HUMANOS, tendo sido deliberado que o referido projeto não envolve manipulação animal ou humana que justifique uma aprovação quanto aos princípios éticos exigidos por ambas as Comissões.

São Paulo, 21 de setembro de 2010.

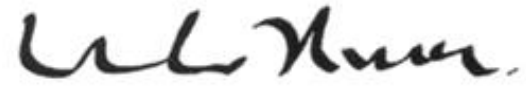

PROF. DR. WOTHAN TAVARES DE LIMA Coordenador da CEUA - ICB/USP

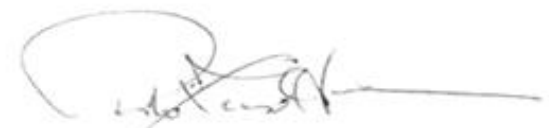

PROF. DR. PAOLO M.A Z.ANOTTO Coordenador da CEPsh - ICB/USP 
Dedico esse trabalho à minha família, minha principal fonte de conhecimento. A meu pai Luiz Roberto, pelo exemplo de determinação e perseverança. Pai, seu exemplo de vida me fez acreditar que, assim como você, eu poderia conquistar o que quisesse. À minha mãe Sandra, pelo apoio cúmplice e incondicional. Você me criou com tanto carinho e dedicação que me ensinou, dentre outras coisas, a ter dedicação pelo meu trabalho. À Gabriela, minha irmã caçula, pelas madrugadas passadas em claro me dando conselhos, incentivando e apoiando e me olhando com aqueles olhos verdes de admiração, que me ajudaram a chegar até aqui.

Por mais que não entendessem nada desse mundo científico, sempre me apoiaram e me deram forças para que eu pudesse concluir essa etapa importante da minha vida. A vocês, meus amores, meu muito obrigada! 


\section{AGRADECIMENTOS ESPECIAIS}

Ao Prof. Dr. Ruy Gastaldoni Jaeger, por me abrir as portas de seu Laboratório, e assim, ter me dado a oportunidade de desenvolver esse trabalho. Obrigada pelo apoio e suporte prestados desde a Iniciação Científica. O senhor me deu subsídios para aprender e também me ensinou tudo sobre ciência. Aprendi com o senhor desde como planejar um experimento, até como analisar e expor seus resultados. Tudo sempre com muita competência e qualidade. Os conhecimentos adquiridos com a minha passagem pelo seu Laboratório foram essenciais para minha formação e estarão sempre comigo. Se esse trabalho está sendo apresentado hoje, é por que um dia pude contar com a sua ajuda para realizá-lo. Muito obrigada por tudo!

À Msc. Adriane Sousa de Siqueira, por todo o tempo que dedicou a mim, me dando apoio técnico e científico. Obrigada pela valiosa colaboração prestada ao trabalho com o processamento de imagens no software Volocity. Agradeço também pelos conselhos e correções que foram extremamente importantes para o meu Mestrado como um todo. Agradeço, mais ainda, pela sua amizade. Fora do laboratório, você também é uma grande companheira. Obrigada pelas horas de conversa, por sempre ter me acolhido em sua casa. Você é alguém que sempre irei admirar com profissional e também como ser humano.

Ao Prof. João de Jesus Viana Pinheiro, pela valiosa colaboração com experimentos de imunohistoquímica desse trabalho. Foi um prazer imenso têlo, não somente como colaborador em meu trabalho, mas também poder participar de seus trabalhos como colaboradora. Considero essa experiência extremamente relevante para minha formação acadêmica e agradeço pela oportunidade concedida. Além disso, conviver com você no Laboratório foi um aprendizado muito grande para mim. Você é um exemplo de determinação e competência, e também, uma pessoa maravilhosa. Aprendi muito com seus ensinamentos. Muito obrigada pela amizade e carinho! 
À Dra. Letícia Nogueira da Gama de Souza, que com muita boa vontade e paciência, dedicou grande parte do seu tempo para o meu treinamento. Instruiu-me na arte de fazer ciência, tanto na realização de experimentos, como na elaboração de relatórios científicos. Foi minha co-orientadora na Iniciação Científica, me dando subsídios para o ingresso na Pós-graduação. Considero você um exemplo a ser seguido. Admiro sua determinação, persistência e próatividade. Agradeço também por ter participado de momentos cruciais da minha vida, se mostrando sempre muito preocupada e prestativa.

Ao Luiz Rogério, meu noivo, melhor amigo e companheiro. Você é uma das pessoas mais especiais que já conheci na minha vida. Agradeço pela compreensão e carinho, e por ter compartilhado das minhas decepções e vitórias. Seu amor e companheirismo me deram tranquilidade e sabedoria para a realização dessa jornada. Sem dúvida você é a pessoa que eu quero que esteja ao meu lado sempre.

À Profa. Dra. Vanessa Morais Freitas, pela inestimável colaboração neste trabalho. Agradeço pelas sugestões, pelo treinamento e pela paciência para responder minhas dúvidas que você teve desde a minha Iniciação Científica. Nas últimas etapas desse trabalho, o apoio técnico prestado com relação ao uso de equipamentos do seu Laboratório foi essencial para os meus experimentos de "immunoblot" e finalização desse trabalho. Obrigada ainda pela amizade, pelo afeto, e por toda ajuda extra-laboratório que você me deu. 


\section{AGRADECIMENTOS}

À Fundação de Amparo e Pesquisa do Estado de São Paulo (FAPESP), pelo suporte financeiro. A concessão de bolsa de mestrado e reserva técnica essencial para a realização deste trabalho.

À Profa. Dra. Telma Zorn e sua equipe, por toda atenção e disponibilidade prestadas ao nosso grupo. Obrigada por ceder o espaço do seu laboratório para a realização de experimentos de cultura celular, e também por permitir o uso de seus equipamentos. Sua ajuda foi fundamental para a execução desse projeto.

À Profa. Dra. Gláucia Maria Machado-Santelli e seu grupo, pelo carinho e colaboração. Agradeço pelos equipamentos cedidos, troca de reagentes e permissão para utilização da sala multi-usuário.

À Profa. Dra. Irene Yan e sua equipe, sempre muito atenciosos, que gentilmente permitiram a utilização dos equipamentos de seu laboratório.

Ao Prof. Jarbas Arruda Bauer, por tudo o que me ensinou durante a disciplina "Conceitos, métodos e diagnósticos em biologia tecidual". Obrigada por ser sempre muito prestativo, e por ter me contagiado com sua paixão pela Histologia.

À Profa. Dra. Patrícia Gama, pelas sugestões durante as aulas preparatórias para o curso de Difusão Científica e pela oportunidade de participar dessa nova modalidade do curso. Gostaria ainda de parabenizá-la pela iniciativa, que é muito importante para a divulgação do conhecimento científico adquirido na Pós-Graduação e para o aprimoramento da educação no país.

Às Profas. Dras. Marinilce Santos, Alison Colquhoun e Silvya Stuchi, pelas relevantes observações e sugestões feitas durante meu exame de qualificação. 
Aos meus colegas de Laboratório: Adriane, Emerson, Edilberto, Karen, João, Luciana, Milza, Micael, Monique Renato e Raphael. Obrigada pela amizade e apoio. Trabalhar ao lado de todos vocês foi uma experiência incrível e também divertida. Adriane e João, obrigado pela valiosa colaboração no trabalho e também por serem sempre tão prestativos e carinhosos. Emerson, obrigada pela confiança que sempre depositou em mim e por possibilitar o nascimento de uma amizade tão bonita e verdadeira. Renato apesar de você não ter continuado no Laboratório, foi um prazer ser sua "tutora". Micael e Monique para mim também é um prazer imenso poder participar, de alguma forma, da formação de vocês. Karen, Luciana e Milza obrigada pela ajuda e pela torcida. Raphael e Edilberto agradeço a vocês pelo apoio técnico. Vocês todos fizeram ou fazem parte da minha família uspiana.

Aos membros da Comissão de Pós-Graduação Profa. Dra. Dânia HamassakiBrito, Profa. Dra. Marinilce Santos, Profa. Dra. Marília Seelaender e Profa. Dra. Edna Kimura, obrigado pela busca por melhorias de nosso departamento. Agradeço também aos funcionários da secretaria, pela dedicação e atenção.

Às minhas amigas de graduação que também fizeram parte dessa história. Danielle, Lívia e Raquel, muito obrigada pelo apoio e pela amizade. Cada uma de vocês, com seu jeito especial, me completa de alguma forma. Danielle obrigada por me ouvir nos momentos de desespero e também compartilhar das alegrias. Lívia, obrigada por estar sempre presente como amiga e companheira durante a realização desse trabalho. Apesar de não trabalhar na mesma linha de pesquisa, você sempre me prestou auxílio, lendo meus relatórios, assistindo as minhas apresentações e ajudando na elaboração da aula apresentada no processo de qualificação. Raquel quando estava desanimada, você sempre me mostrou que a vida pode ser muito mais simples e divertida do que imaginamos.

Aos meus sogros, Bernadete e Luiz Carlos, e à minha cunhada Juliana, que sempre me acolheram em seu ambiente familiar, e me deram todo suporte durante a realização desse trabalho. Obrigada pela hospitalidade e pelo carinho. 
"Enquanto mais me aprofundo nas ciências, mais me aproximo de Deus." 


\section{RESUMO}

NASCIMENTO, C. F. Papel de peptídeos bioativos da laminina na atividade dos invadopódios em linhagem celular derivada de carcinoma adenóide cístico. 2011.116 f. Dissertação (Mestrado em Biologia Celular e Tecidual) Instituto de Ciências Biomédicas, Universidade de São Paulo, São Paulo, 2011.

O carcinoma adenóide cístico é uma neoplasia maligna de glândula salivar com alto grau de recorrência e metástase à distância, mesmo após longo período de tratamento. Células tumorais que degradam e invadem tecidos subjacentes formam estruturas, denominadas invadopódios, para degradar a matriz extracelular (MEC). Os invadopódios são protrusões de membrana ricas em actina, cortactina e MT1-MMP que possuem atividade de degradação da matriz. Proteólise de moléculas da MEC promove liberação de fragmentos com atividade biológica, denominados peptídeos bioativos. As lamininas são os principais componentes da membrana basal. Já demonstramos que a laminina-111 e seus peptídeos bioativos regulam o fenótipo de diferentes células tumorais. Nesse trabalho, estudamos o papel dos peptídeos da laminina-111, AG73 e C16, na atividade de invadopódios das células derivadas de carcinoma adenóide cístico (células CAC2). Para tanto, realizamos ensaio de degradação de substrato fluorescente com células CAC2 tratadas por esses peptídeos. Nossos resultados mostraram que AG73 e C16 regulam a atividade de invadopódio dessas células. Além disso, "immunoblot" mostrou que esses peptídeos aumentaram expressão de MT1MMP células CAC2. Estudamos também receptores e vias de sinalização que podem estar relacionados aos sinais gerados por AG73 e C16. Silenciamento de integrina $\beta 1$ com RNAi diminuiu a atividade de invadopódio induzida por esses peptídeos. Inibição da via ERK também dimunuiu a atividade de invadopódios de ambos os peptídeos. Já a inibição da via Rac diminuiu a atividade de invadopódios induzida pelo peptídeo AG73. Propomos que os peptídeos da laminina-111, AG73 e C16, regulam a atividade de invadopódios através da integrina $\beta 1$ e da via ERK 1/2. Já a via Rac1 tranduziria os sinais gerados apenas pelo peptídeo AG73.

Palavras-chave: Carcinoma Adenóide cístico. Invadopódio. Laminina. 


\begin{abstract}
NASCIMENTO, C. F. Role of laminin-111 derived peptides in invadopodia activity of a human adenoid cystic carcinoma cell line. 2011. 116 p. Masters Thesis (Cell and Tissue Biology) - Instituto de Ciências Biomédicas, Universidade de São Paulo, São Paulo, 2011.
\end{abstract}

Adenoid cystic carcinoma is a frequently occurring malignant salivary gland neoplasm with high level of recurrence and distant metastasis long time after treatment. Metastatic tumor cells that actively migrate and invade surrounding tissues rely on invadopodia to degrade extracellular matrix (ECM) barriers. Invadopodia are actin- and cortactina-rich membrane protrusions that localize enzymes, such as MT1-MMP required for ECM degradation. Breakdown of ECM macromolecules release fragments and bioactive peptides. Laminins are main basement membrane proteins. We have already demonstrated that laminin-111 and its derived peptides regulate phenotype of tumor cells in different cancer models. Here we addressed the role of laminin-111 peptides AG73 and C16 in invadopodia activity of cells (CAC2) derived from human adenoid cystic carcinoma. Cells cultured in Dulbecco's modified Eagle's medium serum-starved were treated with either AG73 or C16. After treatment CAC2 cells were subjected to fluorescent gelatin substrate degradation assay. Our results showed that AG73 and C16 significantly increased invadopodia formation and activity compared to controls. Furthermore, immunoblot showed that these peptides enhanced MT1-MMP expression in CAC2 cells. We analyzed putative receptors and signaling pathways related to peptide effects. Silencing of $\beta 1$ integrin by siRNA decreased AG73- and C16-induced invadopodia. Inhibition of Rac signaling pathway by NSC23766 decreased AG73-induced invadopodia formation in CAC2 cells. Furthermore, inhibition of ERK 1/2 signaling pathway by U0126 decreased both C16- and AG73-related invadopodia activity. We propose that laminin-111 peptides $A G 73$ and $C 16$ increase invadopodia activity in CAC2 cells through $\beta 1$ integrin. ERK1/2 signaling pathway would transduce signals generated by both peptides, while Rac1 pathway is related to AG73 signaling.

Key-words: Adenoid cystic carcinoma. Invadopodia. Laminin. 


\section{LISTA DE ABREVIATURA E SIGLAS}

AG73 seqüência dos aminoácidos RKRLQVQLSIRT (arginina-lisina-argininaleucina-glicina-valina-glicina-leucina-serina-isoleucina-arginina-treonina)

BSA do inglês "Bovine Serum Albumine" traduzido como albumina sérica bovina

${ }^{\circ} \mathrm{C}$

graus Celsius

$\mathrm{Ca}^{2+}$

íon cálcio

C16 sequência dos aminoácidos KAFDITYVRLKF (lisina-asparaginafenilalanina-ác. aspártico-isoleucina-treonina-tirosina-valina-argininaleucina-lisina- fenilalanina)

$\mathrm{cm}^{2} \quad$ centímetros quadrados

$\mathrm{CO}_{2} \quad$ gás carbônico

DMEM do inglês "Dulbecco's Modified Eagles' Medium" traduzido como meio de Eagle modificado por Dulbecco

DMSO di-metil sulfóxido

EDTA do inglês "ethylenediamine-tetra acetic acid" traduzido como ácido etilenodiamino tetra acético

EGF do inglês "epidermal growth receptor", traduzido como fator de crescimento epidermal

ERK do inglês "extracellular response kinase", traduzida como quinase de resposta extracelular

Fig. $\quad$ Figura

F-actina Actina do tipo filamentosa

g gravidade

h horas

HGF do inglês "hepatocyte growth factor" traduzido como fator de crescimento de hepatócito

HSG do inglês "human submandibular gland", traduzido como glândula submandibular humana

INCA Instituto Nacional do Câncer

$\mathrm{kDa} \quad$ kilodalton

M molar

$\mathrm{mM} \quad$ milimolar

$\mu \mathrm{m}^{2} \quad$ micrometrtos quadrados

$\mu \mathrm{M} \quad$ micromolar

$\mathrm{mg} \quad$ miligramas

$\mu \mathrm{g} \quad$ microgramas

$\mu \mathrm{g} / \mathrm{ml} \quad$ microgramas por mililitros

$\mathrm{ml} \quad$ mililitro

mm milímetro 
$\mathrm{mM} \quad$ milimolar

MAP do inglês "mitogen-activated-protein" traduzido como proteína ativada por mitógeno

MEC matriz extracelular

MMPs do inglês "matrix metalloproteases" traduzido como metaloproases de matriz

MT-MMP do inglês "membrane type matrix metalloproteases" traduzido como metaloproases de matriz associadas à membrana

MT1-MMP do inglês "membrane type-1 matrix metalloproteases" traduzido como metaloproases de matriz associadas à membrana do tipo 1

$\mathrm{NaCl} \quad$ cloreto de sódio

$\mathrm{Na}_{2} \mathrm{HPO}_{4} \quad$ fosfato de sódio

NIDCR do inglês "National Institute of Dental and Craniofacial Research

$\mathrm{NIH}$ do inglês "National Institutes of Health"

nm nanômetro

N-WASP do ingles "neuronal Wiskott-Aldrich Syndrome protein", traduzido como proteína neural da síndorme de Wiskott-Aldrich

OMS Organização Mundial de Saúde

PBS do inglês "phosphate-buffered saline", traduzido como tampão fosfatosalina

PDGF do inglês "platelet-derived growth factor", traduzido como fator de crescimento derivado de plaqueta

pH cologarítmo da concentração hidrogeniônica de uma solução (potencial hidrogeniônico)

PMSF do inglês "phenylmethylsulphonyl fluoride", traduzido como fluoreto de fenilmetilsulfonil, é um inibidor de serina protease

Src do inglês "sarcoma rous oncogene", traduzido como oncogene do vírus do sarcoma rous

SDS-PAGE do inglês "sodium dodecyl sulfate polyacrylamide gel electrophoresis" eletroforese de gel de poliacrilamida, tendo como agente denaturante sulfato dodecil sódico

SFB soro fetal bovino

SH3 domínio possui homologia com Src

TBS do inglês "Tris-buffered saline", traduzido como tampão tris-salina

TEM transição epitélio-mesênquima

TGB $\beta$ do inglês "tranforming growth factor beta" traduzido como fator beta de transformação do crescimento

TNG do inglês "trans-Golgi-netwok" traduzido como rede do trans-Golgi

YIGSR seqüência dos aminoácidos (tirosina-isoleucina-glicina-serina-arginina)

$\mathrm{Zn}^{2+} \quad$ íon zinco 


\section{LISTA DE SÍMBOLOS}
$\alpha \quad$ alfa
$\beta$ beta
$\gamma \quad$ gama 


\section{LISTA DE ILUSTRAÇÕES}

Figura 1 - Cortactina e MT1-MMP estão presentes no carcinoma adenóide cístico in vivo

Figura 2 - AG73 aumenta atividade de invadopódios nas células CAC2........ 65

Figura 3 - C16 regula atividade invadopódios nas células CAC2.

Figura 4 - Restauração algorítmica e reconstrução tri-dimensional evidenciam interação célula-matriz.

Figura 5 - Peptídeos da laminina não regulam atividade de invadopódio nas células HSG.

Figura 6 - AG73 aumenta a expressão de MT1-MMP nas células CAC2....... 74

Figura.7 - C16 aumenta a expressão de MT1-MMP nas células CAC2. 76

Figura 8 - Subunidade $\beta 1$ da integrina regula invadopódios induzidos por AG73 nas células CAC2.

Figura 9 - Subunidade $\beta 1$ da integrina modula invadopódios induzidos por C16 nas células CAC2.

Figura 10 - A via ERK participa dos sinais gerados pelo peptídeo AG73 nas células CAC2.

Figura 11 - A via ERK participa dos sinais gerados pelo peptídeo C16 nas células CAC2...

Figura 12 - A via Rac1 participa dos sinais gerados pelo peptídeo AG73 nas células CAC2.

Figura 13 - A via Rac1 parece não estar envolvida nos sinais gerados pelo peptídeo C16 nas células CAC2. 


\section{LISTA DE TABELAS}

Tabela 2.1 - Isoformas da laminina, suas respectivas cadeias e integrinas ligantes.

Tabela 4.1 - Peptídeos derivados da laminina-111 e seus controles peptídeos "scrambled" que foram utilizados no presente trabalho. A tabela demonstra sequência de aminoácidos, cadeia e isoforma da laminina a que os peptídeos estão relacionados. 


\section{SUMÁRIO}

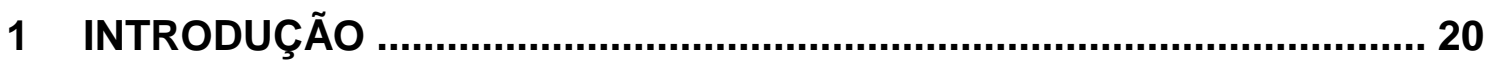

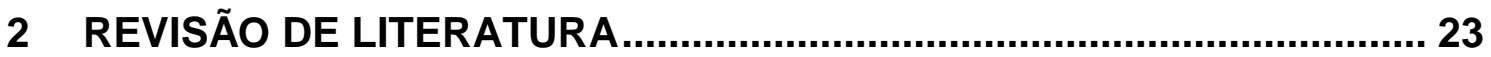

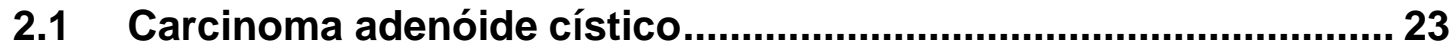

2.2 Matriz Extracelular e Membrana Basal ......................................... 27

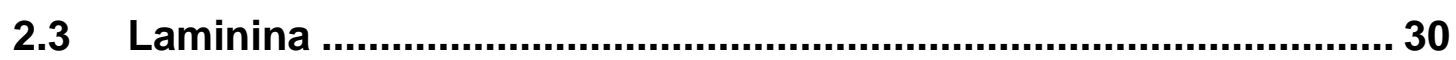

2.3.1 Laminina-111 e peptídeos bioativos derivados AG73 e C16 ........ 34

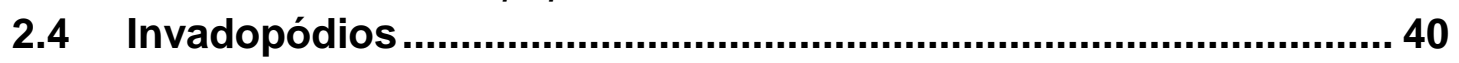

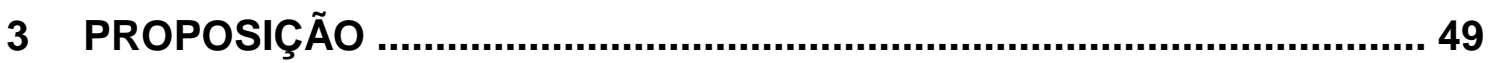

4 MATERIAL E MÉTODOS................................................................. 50

4.1 Detecção de proteínas do invadopódio no Carcinoma adenóide

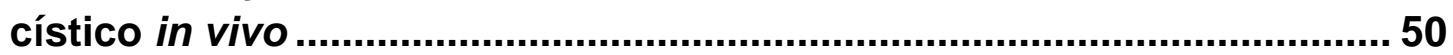

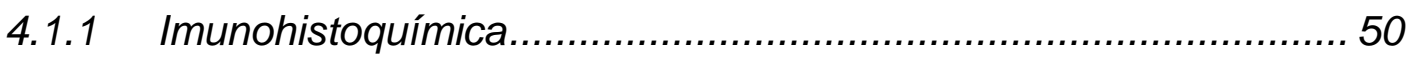

4.2 Peptídeos bioativos da laminina ................................................. 51

4.3 Papel dos peptídeos AG73 e C16 na atividade de invadopódio da

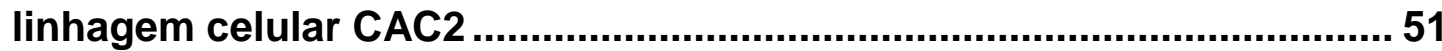

4.3.1 Cultura da linhagem celular CAC2........................................... 51

4.3.2 Preparação de substrato para ensaio de degradação de substrato

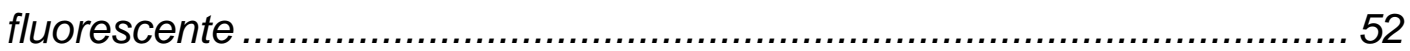

4.3.3 Ensaio de degradação de substrato fluorescente e detecção de invadopódios em células tratadas por peptídeos da laminina.................... 52

4.3.4 Microscopia de fluorescência ................................................... 54

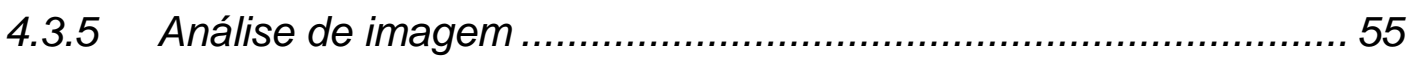

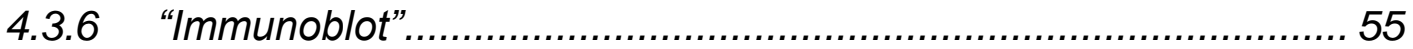

4.4 Estudo do papel da integrina $\beta 1$ na atividade de invadopódio mediada por AG73 e C16 em células CAC2 …...................................... 57

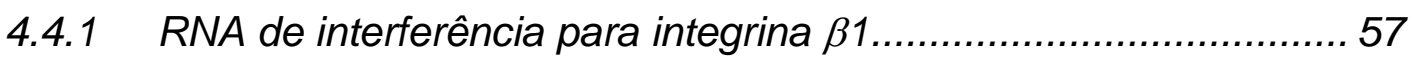

4.4.2 "Immunoblot" para análise da eficiência de inibição de integrina- $\beta 1$..... 57

4.4.3 Ensaio de degradação de substrato fluorescente e detecção de invadopódios em células inibidas para integrina- $\beta 1$............................... 58

4.5 Estudo das vias de sinalização envolvidas na atividade de invadopódio mediada por AG73 e C16 em células CAC2 ….................... 58

4.5.1 Inibição das vias de sinalização ERK1/2 e Rac1 seguido de ensaio de degradação de substrato fluorescente............................................. 58 4.5.2 "Immunoblot" para análise da eficiência de inibição da via ERK1 59

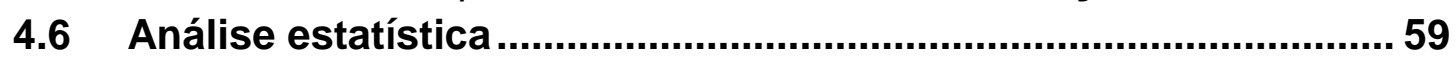

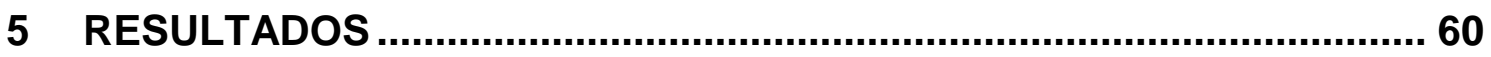

5.1 Marcadores de invadopódio estão expressos no Carcinoma

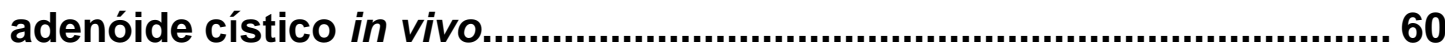


5.2 Peptídeos da laminina-111 aumentam atividade de invadopódio nas células CAC2, mas não nas células HSG .

5.3 Peptídeos da laminina-111 aumentam a expressão de MT1-MMP nas células CAC2

5.4 Integrina- $\beta 1$ medeia atividade de invadopódio induzida pelos peptídeos da laminina nas células CAC2

5.5 Via de sinalização ERK participa da atividade de invadopódio induzida pelos peptídeos da laminina-111

5.6 Via de sinalização Rac1 participa da atividade de invadopódio induzida pelo peptídeo AG73

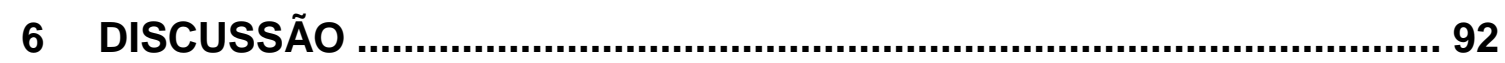

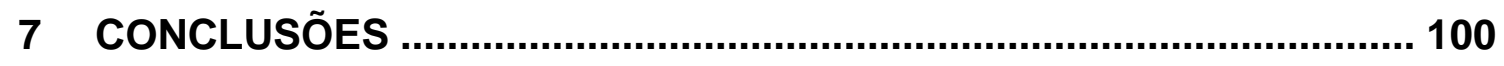

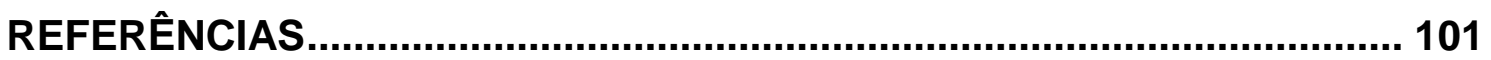




\section{INTRODUÇÃO}

O carcinoma adenóide cístico é uma neoplasia maligna de glândula salivar com recorrência e metástase mesmo após tratamento (SEIFERT e SOBIN, 1992; COLOGNATO e YURCHENCO, 2000; CONDEELIS e SEGALL, 2003; WEAVER, 2006; BUCHNER et al., 2007). Exibe diferentes subtipos histológicos, podendo ser sólido, tubular ou pseudo-cístico (SEIFERT e SOBIN, 1992; DARDICK, 1996; THOMPSON, 2006). Uma característica importante do carcinoma adenóide cístico é a sua afinidade por tecidos ricos em membrana basal, o que facilita a sua disseminação peri-neural ou peri-vascular (CHENG et al., 1995; DARDICK, 1996).

Tumores de glândula salivar expressam proeminente membrana basal, sendo esse fenômeno particularmente interessante no carcinoma adenóide cístico (CHENG et al., 1995; DARDICK, 1996). Resultados obtidos em nosso laboratório mostraram que a membrana basal do carcinoma adenóide cístico está pelo menos 40 vezes mais espessada do que no tecido normal (GAMA-DE-SOUZA et al., 2008). O aumento da densidade da membrana basal, pode causar uma super-expressão dos componentes dessa estrutura in vivo nas células do carcinoma. A membrana basal é uma rede tridimensional composta por colágeno tipo IV, laminina, perlecan e nidogênio, que representa não somente um sólido suporte para as células, mas também atua como uma fonte de citocinas e fatores de crescimento (EKBLOM, 1996; KLEINMAN et al., 2003; SCHENK e QUARANTA, 2003; MINER e YURCHENCO, 2004; AUMAILLEY et al., 2005).

A laminina é uma glicoproteína heterotrimérica composta por 3 subunidades polipeptídicas $(\alpha, \beta$ e $\gamma$ ) que agrupam-se em uma estrutura $\alpha$-hélice e apresentam domínios globulares e rod-like (COLOGNATO e YURCHENCO, 2000; EKBLOM et al., 2003). Estudos já revelaram que a laminina desempenha diferentes atividades biológicas, como adesão celular, migração, proliferação, diferenciação, angiogênese, crescimento e metástase tumorais (KOSMEHL et al., 1999; PATEL et al., 2002; SUZUKI et al., 2005). Em nosso laboratório, estudamos o papel da laminina no comportamento biológico de tumores de glândula salivar, já demonstramos que a laminina-111, regula o fenótipo de células derivadas do carcinoma adenóide cístico (células CAC2) (FRANCA et al., 2000; FRANCA et al., 2001; FREITAS e JAEGER, 2002; FREITAS et al., 2004; FREITAS et al., 2007; GAMA-DE-SOUZA, 2008; GAMA-DE-SOUZA et al., 2008; JAEGER et al., 2008). 
Diversas linhas de pesquisa mostram que a laminina intacta regula atividades biológicas. Estudos mostram também que a laminina fragmentada biologicamente por proteases exibe funções importantes (DAVIS et al., 2000; GHOSH e STACK, 2000; MOTT e WERB, 2004; DA CRUZ PEREZ et al., 2006). Fragmentos e peptídeos bioativos da laminina influenciam o fenótipo tumoral. Nesse contexto, múltiplas sequências ativas da laminina têm sido identificadas através de fragmentos proteolíticos, proteínas recombinantes e peptide screening. Essas sequências estão envolvidas em diferentes atividades biológicas, incluindo adesão, migração, diferenciação, angiogênese e secreção de protease (GRANT et al., 1992; MALINDA e KLEINMAN, 1996; HOFFMAN et al., 1998; NOMIZU et al., 1998; FREITAS e JAEGER, 2002; FREITAS et al., 2004; FREITAS et al., 2007; GAMA-DE-SOUZA, 2008; GAMA-DE-SOUZA et al., 2008).

Em nosso Laboratório, estudamos o papel de peptídeos bioativos derivados da laminina-111 em tumores de glândulas salivares. Destacamos os peptídeos AG73 (RKRLQVQLSIRT, cadeia $\alpha 1$ ) e C16 (KAFDITYVRLKF cadeia $\gamma 1$ ). Ambos os peptídeos estão envolvidos com invasão e secreção de proteases em células CAC2 (GAMA-DE-SOUZA, 2008; GAMA-DE-SOUZA et al., 2008). Dessa forma, possuímos fortes evidências que tanto a laminina-111 quanto seus peptídeos bioativos estão envolvidos em processos biológicos em células CAC2 e que podem ter papel relevante na invasão e metástase tumorais.

Invasão e mestástase de tumores malignos, como o carcinoma adenóide cístico, envolvem múltiplas etapas e diferentes moléculas. Para que ocorra o processo de metástase, primeiramente as células devem se separar do tumor primário para posteriormente invadir e migrar para tecidos subjacentes e vasos sanguíneos (CHAMBERS et al., 2002). A etapa inicial dos processos de migração e invasão é a extensão de protrusões da membrana em direção ao movimento da célula (FRIEDL e WOLF, 2003). Por outro lado, a habilidade de degradar a MEC é uma característica marcante de tumores invasivos e é considerada importante para - movimento dessas células através de barreiras teciduais (PANTEL e BRAKENHOFF, 2004; NAKAGAWA et al., 2006). Essa atividade de degradação celular tem sido relacionada com protrusões finger-like ricas em actina, denominadas invadopódios. 
Os invadopódios são estruturas características de células invasivas, exibindo protrusões celulares com atividade de degradação da matriz peri-celular. Originamse na região ventral da membrana, se estendendo verticalmente para a matriz extracelular (CHEN et al., 1985; CHEN, 1989; CONDEELIS e SEGALL, 2003; WEAVER, 2006). Essas estruturas são ricas em microfilamentos de actina e proteínas associadas à actina. Além disso, exibem proteínas de adesão, proteases de matriz e moléculas sinalizadoras que regulam o citoesqueleto de actina e a remodelação da membrana (BUCCIONE et al., 2004). Para entender os mecanismos envolvidos na dinâmica dos invadopódios, estudos envolvem principalmente duas proteínas, cortactina e MT1-MMP. A primeira é capaz de monitorar mudanças no citoesqueleto, tendo papel estrutural; enquanto que a segunda está envolvida com a degradação da MEC, tendo uma atividade funcional nos invadopódios (ARTYM et al., 2006).

Já caracterizamos os invadopódios na linhagem CAC2. Verificamos a presença das proteínas cortactina e MT1-MMP nos invadopódios dessas células (NASCIMENTO et al., 2009). Nesse trabalho, verificamos os efeitos dos peptídeos AG73 e C16 na formação de invadopódios na linhagem celular derivada de carcinoma adenóide cístico humano (células CAC2). Analisamos também possíveis receptores e vias de sinalização que podem estar relacionados às atividades biológicas induzidas por AG73 e C16 em células CAC2. 


\section{REVISÃO DE LITERATURA}

$\mathrm{Na}$ revisão de literatura serão abordados os seguintes temas relacionados a essa dissertação: 1) Carcinoma adenóide cístico, neoplasia maligna que deu origem à linhagem celular utilizada nesse estudo; 2) Conceitos básicos sobre matriz extracelular e membrana basal, com destaque para a laminina e suas atividades biológicas; 3) Laminina-111 e peptídeos derivados AG73 e C16, objetos de estudo desse trabalho; 4) Invadopódios, estruturas relacionadas a invasão celular, e suas proteínas de interesse.

\subsection{Carcinoma adenóide cístico}

Os tumores de cabeça e pescoço correspondem a mais de $5 \%$ de todas as neoplasias malignas que acometem o ser humano, sendo a cavidade oral a região mais afetada (LANDIS et al., 1999; EPSTEIN e SCHUBERT, 2003). De acordo com a Organização Mundial da Saúde (OMS, 2008), os tumores da cavidade oral são o sétimo tipo de câncer mais comum entre os homens e o décimo segundo entre mulheres, provocando cerca 400.000 mortes por ano no mundo todo.

Os países subdesenvolvidos são os mais afetados por esse tipo de câncer. $\mathrm{Na}$ índia, os tumores bucais chegam a representar a segunda maior causa de mortalidade (OMS, 2008). No Brasil, a cavidade oral é o sétimo local mais acometido por neoplasias malignas, com estimativa de 14.120 novos casos para o ano de 2010. Nos homens, representa o quinto tumor maligno mais prevalente, enquanto que nos mulheres é o sétimo (INCA, 2007).

Embora relativamente raras, as neoplasias de glândula salivar são consideradas relevantes na patologia bucal e maxilofacial (NEVILLE et al., 2004; ITO et al., 2005; SUBHASHRAJ, 2008). O carcinoma adenóide cístico (CAC) representa $10 \%$ de todas as neoplasias de glândula salivar, (SPIRO et al., 1979; CHUMMUN et al., 2001; KHAN et al., 2001b; WISEMAN et al., 2002; BRADLEY, 2004) $22 \%$ de todas as neoplasia malignas de glândula salivar (HOTTE et al., 2005) e cerca de $1 \%$ de todas as malignidades que acometem a região de cabeça e pescoço (CHUMMUN et al., 2001; WISEMAN et al., 2002).

Em trabalho de Ito et al. (2005) foi realizada uma análise epidemiológica dos tumores de glândula salivar no Brasil. Um total de 496 casos de neoplasias 
localizadas tanto em glândulas salivares maiores quanto em menores foram resgatados e analisados. Desse número, 67,5\% dos casos foram diagnosticados como benignos e $32,5 \%$ como malignos. O carcinoma adenóide cístico foi o quarto tumor mais comum $(7,9 \%)$ e o segundo maior no grupo dos tumores malignos, com $24,2 \%$ dos casos diagnosticados.

Trabalho semelhante foi realizado por Subhashraj (2008), na Índia, onde 684 casos de tumores de glândula salivar foram analisados e a neoplasia maligna mais frequente foi o carcinoma adenóide cístico, representando 25\%.

O carcinoma adenóide cístico foi descrito inicialmente por Billroth em 1859 sob denominação de cilindroma (MYLIUS, 1960). Esse termo retrata graficamente o padrão estrutural desse tumor, ilhas epiteliais formando espaços no seu interior contendo mucina ou material hialino (FRIEDMAN e SCHWARTZ, 1974). Embora o termo cilindro ainda seja utilizado, a OMS recomenda o termo "carcinoma adenóide cístico" o qual foi primeiramente utilizado por Ewing em 1919 (THOMPSON, 2006).

Esse tipo de tumor acomete com maior frequência glândulas salivares menores, não havendo discordância quanto à maior prevalência de envolvimento de glândulas menores da região do palato (LOYOLA et al., 1995; DA CRUZ PEREZ et al., 2006; BUCHNER et al., 2007; KO et al., 2007). Não há o mesmo consenso com relação ao seu acometimento em glândulas maiores, havendo relatos de maior incidência em parótida (KHAN et al., 2001a), outros de maior incidência em submandibular (EVESON e CAWSON, 1985; KO et al., 2007), e, ainda, aqueles mostrando incidência igual entre as glândulas (BOUKHERIS et al., 2009).

Estudos indicam que o CAC se origina a partir de células de reserva do ducto intercalado. Também estão presentes no tumor, células secretoras, mioepiteliais e pluripotentes/células tronco (EVERSOLE, 1971; REGEZI e BATSAKIS, 1977). Dentre elas, as células mioepitelais são encontradas em cada 9 de 12 tumores (CHAUDHRY et al., 1986). As células desse tumor podem se arranjar em três padrões distintos de organização: cribriforme, tubular, e sólido. Entretanto, os três subtipos podem coexistir no mesmo tumor. Neste caso, o diagnóstico do tumor é dado pela predominância de um dos subtipos (THOMPSON, 2006).

No padrão cribriforme, as células tumorais se encontram distribuídas em uma forma semelhante a "crivo" ou "queijo suíço" ao redor dos espaços que lembram 
lúmen. Esses espaços são conhecidos como espaços pseudo-císticos e contém material hialino ou mucoso. Os espaços pseudo-císticos são envolvidos por uma lâmina basal comum, formando grandes unidades (CHAUDHRY et al., 1986; SEIFERT e SOBIN, 1992; DARDICK, 1996). Esse é o padrão mais clássico e com o aspecto melhor conhecido (CHAUDHRY et al., 1986; NEVILLE et al., 2004).

Já o padrão tubular é considerado o padrão histológico em melhor estado de diferenciação, pois o arranjo das células simula aquele visto no tecido normal. Células de fenótipo ductal formam a camada luminal (interna) e células de fenótipo mioepitelial formam a camada abluminal (externa) (KO et al., 2007). Esse aspecto histológico é o mais encontrado dentre os subtipos.

A neoplasia também pode apresentar o padrão sólido. Esse por sua vez, é caracterizado pela formação de massas celulares agregadas, formando ilhotas e lençóis tumorais sem a formação tubular ou pseudo-cística. Diferente dos demais padrões, no tipo sólido é possível observar pleomorfismo celular, atividade mitótica e necrose focal nos centros do tumor (CHAUDHRY et al., 1986; SEIFERT e SOBIN, 1992; DARDICK, 1996; RAITZ et al., 2003). Este último subtipo é considerado o mais agressivo (KOKEMUELLER et al., 2004; DA CRUZ PEREZ et al., 2006; KO et al., 2007).

O CAC mostra predileção por pacientes na quinta e sexta décadas de vida (LOYOLA et al., 1995; BUCHNER et al., 2007), sendo a predileção entre gêneros controversa (KOKEMUELLER et al., 2004; DA CRUZ PEREZ et al., 2006; BUCHNER et al., 2007; KO et al., 2007; BOUKHERIS et al., 2009). Com relação aos sinais e sintomas, dor local é relatada por $50 \%$ dos pacientes, provavelmente devido á infiltração perineural do tumor. A invasão perineural foi definida como, células tumorais que envolvem feixes nervosos em bainhas contínuas e concêntricas (VAN DER WAL et al., 1990).

O carcinoma adenóide cístico não é encapsulado, possuindo crescimento é lento e insidioso, com tendência a desenvolvimento de metástase à distância e recorrência local, mesmo após tratamento. Por essa razão, pacientes precisam ser acompanhados por períodos acima de dez anos (FRIEDMAN e SCHWARTZ, 1974; SIMPSON et al., 1984; NEVILLE et al., 2004; BIANCHI et al., 2008). O tratamento usualmente envolve combinação de excisão cirúrgica e radioterapia. Alguns autores defendem a hipótese de que a radioterapia pós-operatória pode oferecer vantagem à 
sobrevida de pacientes de alto risco (GARDEN et al., 1995; RENEHAN et al., 1999; MACIEJEWSKI et al., 2002).

Alguns estudos demonstram que a lesão tem um potencial para desenvolver metástases à distância desde as fases precoces do desenvolvimento tumoral (GARDEN et al., 1995; WAHLBERG et al., 2002; KOKEMUELLER et al., 2004). Segundo Guzzo et al. (2010), as metástases direcionam-se preferencialmente para pulmões (80\%), ossos (15\%), fígado e outros sítios (5\%), podendo surgir até mesmo depois de 20 anos após a excisão do tumor primário, o que representa a principal causa de falhas no tratamento (GUZZO et al., 2010).

Um trabalho avaliou os fatores que influenciam a taxa de sobrevida de pacientes diagnosticados com CAC (HUANG et al., 1997). Os autores concluíram que o sítio do tumor, estágio clínico e subtipo histológico são fatores importantes no prognóstico da doença. Lesões localizadas no palato ou parótida, em estágio clínico inicial, de subtipo histológico tubular e sem envolvimento de nervos foram as que tiveram os melhores prognósticos. Por outro lado, as lesões localizadas em glândula submandibular e língua, em estágio avançado, de subtipo histológico sólido e com envolvimento de nervos, apresentaram pobre prognóstico.

Cheng et al. (1992) observaram uma característica importante desse tumor No estudo, foi constatada presença abundante de proteínas da membrana basal, em especial da lamimina, nos espaços pseudo-císticos e em todo o estroma tumoral. Também observaram uma tendência de proliferação de células tumorais em contato com a matriz extracelular, além de infiltração através de tecidos ricos em membrana basal, como vasos e nervos. Os autores concluíram que a alta afinidade por membranas basais poderia ser responsável pelo aspecto morfológico e comportamento biológico do CAC (CHENG et al., 1992).

Além disso, outros achados demonstram que essa neoplasia expressa proeminente membrana basal. Nossos estudos já demonstraram espessamento de 40X na neoplasia comparado com a junção dermo-epidérmica normal (GAMA-DESOUZA et al., 2008). Esses dados corroboram com achados anteriores (VISSE e NAGASE, 2003). Vários trabalhos demonstram que diferentes componentes da membrana basal desempenham importante papel não somente na morfogênese de glândulas salivares normal, mas também nas características e atividades de tumores localizados nesses sítios. Dentre esses componentes destacam-se, a laminina e o 
colágeno tipo IV (D'ARDENNE et al., 1986; SAKU et al., 1990; KADOYA et al., 1998; RAITZ et al., 2003).

Para uma melhor compreensão da relação entre o carcinoma adenóide cístico e a matriz extracelular, no tópico subsequente será realizada uma breve descrição sobre a estrutura, os componentes e as funções da matriz extracelular.

\subsection{Matriz Extracelular e Membrana Basal}

O estroma tecidual é formado tanto por componentes celulares, fibroblastos e miofibroblastos, como por uma rede tridimensional complexa e organizada de macromoléculas de suporte conhecida como matriz extracelular (MEC) (MINER e YURCHENCO, 2004; MARASTONI et al., 2008).

Estruturalmente, a MEC contém polímeros fibrosos bem organizados, representados por várias isoformas de colágeno e por elastina, embebidos em mistura amorfa de proteoglicanas e glicosaminoglicanas altamente hidratada, chamada de substância fundamental. Glicoproteínas adesivas, como lamininas, fibronectinas e nidogênio (entactinas) também são encontradas (COLOGNATO e YURCHENCO, 2000; MAO e SCHWARZBAUER, 2005; TANZER, 2006; LI et al., 2007). Proporção entre componentes fibrosos e não fibrosos, diâmetro das fibras e organização de componentes não fibrosos ditam as propriedades físicas da matriz extracelular de um tecido específico. Proteínas da MEC são grandes e multifuncionais, contendo domínios que podem conferir várias funções a uma mesma macromolécula (HOHENESTER e ENGEL, 2002).

A matriz extracelular não é meramente um suporte estrutural para elementos celulares do estroma, e pode influenciar o comportamento celular afetando crescimento, diferenciação, motilidade e viabilidade (TANZER, 2006). As moléculas da MEC podem funcionar como reservatório para várias substâncias secretadas pelas células, que incluem fatores de crescimento, citocinas, metaloproteinases da matriz (MMPs) e enzimas de processamento. Disponibilidade dessas substâncias para as células pode ser regulada através de rearranjos da matriz, como os que ocorrem, por exemplo, durante os processos de cicatrização e de invasão de tumores malignos (MARASTONI et al., 2008). Além do mais, existem vias de comunicação bem desenvolvidas entre as superfícies celulares e a MEC, o que permite às células perceber o ambiente no qual estão inseridas (TANZER, 2006). 
Nesse processo, as células dependem principalmente de receptores transmembrana do tipo integrinas (MOULD e HUMPHRIES, 2004).

A matriz extracelular pode ser dividida em matriz intersticial e membrana basal. Ambas possuem uma estrutura básica composta por colágeno, sendo que a matriz intersticial é formada por colágenos tipicamente fibrilares como o tipo I, e a membrana basal por colágeno tipo IV. Glicoproteínas adesivas, como a laminina, e proteoglicanas, aderem às moléculas de colágeno e interagem com células localizadas na matriz ou adjacentes a ela (BOSMAN et al., 1992; KADLER et al., 1996). Esses componentes da MEC podem ser produzidos tanto por células do parênquima quanto células do estroma de um determinado tecido (TANZER, 2006; ZIOBER et al., 2006).

Virtualmente todos os órgãos e tecidos no adulto possuem uma arquitetura organizada onde células estão aderidas à membrana basal, uma camada fina e flexível de matriz extracelular altamente especializada (COLOGNATO e YURCHENCO, 2000; MINER e YURCHENCO, 2004; YURCHENCO et al., 2004; YURCHENCO e WADSWORTH, 2004; TANZER, 2006). Além de situar-se na interface entre células epiteliais e tecido conjuntivo, a membrana basal também pode ser observada recobrindo células do mesotélio, musculares, células de Schwan e adipócitos (BOSMAN e STAMENKOVIC, 2003). Essa membrana apresenta funções mecânicas de suporte, ancoragem celular e compartimentalização de tecidos, bem como determina a polaridade celular. Nos glomérulos renais e alvéolos pulmonares, atua como um filtro altamente seletivo para sais e pequenas moléculas. Participa ainda de processos de adesão, migração, crescimento e diferenciação celulares, sendo essencial para a formação e manutenção de tecidos tanto nos estágios iniciais de desenvolvimento quanto na fase adulta (COLOGNATO e YURCHENCO, 2000; SUZUKI et al., 2005).

A membrana basal é constituída predominantemente por: 1) colágeno tipo IV, um polímero não fibroso; 2) laminina, glicoproteína adesiva; 3) fibronectina; 4) nidogênio (entactina) e 5) perlecan, uma proteoglicana. Pequenas quantidades de outras proteoglicanas e glicoproteínas também podem ser encontradas (AUMAILLEY, 1995; COLOGNATO e YURCHENCO, 2000; SASAKI et al., 2004; MAO e SCHWARZBAUER, 2005). Estudos de reconstrução mostraram que, durante o processo de organização da membrana basal, o colágeno tipo IV sofre 
polimerização e forma um arcabouço que é reconhecido pela laminina, nidogênio e perlecan. Outras moléculas posteriormente conectam-se a esta estrutura, criando uma rede interligada que se torna resistente e insolúvel (TANZER, 2006). Em relação à ultraestrutura, não existem diferenças de arquitetura significantes entre membranas basais de vários órgãos e tecidos No entanto, sua composição pode apresentar variações, já que diferentes isoformas de colágeno IV e de laminina são sintetizadas dependendo do tecido analisado (AUMAILLEY, 1995; COLOGNATO e YURCHENCO, 2000; BOSMAN e STAMENKOVIC, 2003; TANZER, 2006).

A membrana basal serve como barreira para grandes solutos e é impenetrável para a maioria das células no tecido adulto (TANZER, 2006). Por isso, ela representa o primeiro obstáculo a ser atravessado por células neoplásicas durante o processo de invasão. No entanto, as células tumorais desenvolvem mecanismos que as permitem ultrapassar este obstáculo e migrar para o estroma circundante (BOSMAN et al., 1992; TANZER, 2006).

Para que possam disseminar-se e invadir outras estruturas, células tumorais sofrem mudanças que afetam sua morfologia e comportamento, bem como sua relação com a matriz extracelular e membrana basal (BOSMAN et al., 1992; EPSTEIN e SCHUBERT, 2003; TANZER, 2006). Essas células são capazes de modificar a composição da matriz, alterando o nível de expressão de diferentes proteínas, ou promovendo degradação de componentes por ação de enzimas proteolíticas (STERNLICHT e WERB, 2001; SCHENK e QUARANTA, 2003; MOTT e WERB, 2004). Na membrana basal, especificamente, a ação destas enzimas pode gerar descontinuidades nessa estrutura, facilitando 0 processo de invasão (EPSTEIN e SCHUBERT, 2003; ZIOBER et al., 2006; ALEXANDROVA, 2008). Praticamente todas as modificações da MEC, mesmo que restritas a somente algumas proteínas, resultam em alterações complexas de vias regulatórias envolvendo adesão e proliferação celulares, modificações de citoesqueleto, e relação célula-matriz (ALEXANDROVA, 2008).

Uma maneira de estudar a relação entre as células e a membrana basal, é utilizando Matrigel, que é uma membrana basal reconstituída. Matrigel tem sido utilizado por diversos laboratórios no sentido de preservar, aumentar ou induzir fenótipo de diferentes tipos de células epiteliais (KLEINMAN et al., 1986; BOUDREAU e BISSELL, 1998). Esse substrato contém em sua composição, 
importantes moléculas morforeguladoras como, laminina e colágeno tipo IV, que possuem papel tanto em proliferação como em diferenciação celular (KLEINMAN et al., 1986). Um estudo verificou que células derivadas de carcinoma adenoide cístico cultivadas sobre Matrigel organizam-se em ilhas contendo espaços pseudo-císticos no seu interior (MARQUES et al., 2006). Esse fenótipo reproduz o subtipo histológico cribriforme do CAC verificado in vivo. Isso indica que moléculas da membrana basal são importantes reguladores na diferenciação das células derivadas de carcinoma adenóide cístico. Além disso, marcação de proteínas da membrana basal, laminina, colágeno tipo IV, fibronectina e tenascina, já foi verificada no CAC (RAITZ et al., 2003). Nesse estudo, foi realizada marcação de diferentes moléculas da membrana basal em tumores de glândula salivar, tanto malignos quanto benignos. Uma maior produção de membrana basal, evidenciada pela marcação de laminina e colágenoIV, foi verificada no CAC. Os autores propõem que esse fato pode estar relacionado com invasão tumoral, uma vez que foi verificado apenas nos tumores invasivos.

Em nosso laboratório, estudamos o papel da laminina no comportamento biológico de tumores (JAEGER et al., 1997; FRANCA et al., 2000; DE OLIVEIRA et al., 2001; FRANCA et al., 2001; FREITAS e JAEGER, 2002; CAPUANO e JAEGER, 2004; FREITAS et al., 2004; FREITAS et al., 2007; GAMA-DE-SOUZA et al., 2008). Por tal motivo, abordaremos a seguir alguns aspectos relevantes sobre a estrutura $e$ funções dessa molécula.

\subsection{Laminina}

A laminina é a glicoproteína adesiva mais abundante na membrana basal, e exerce tanto atividades estruturais quanto biológicas (MARTIN e TIMPL, 1987; SASAKI et al., 2004). Essa molécula foi identificada em 1979 por Timpl e colaboradores, depois de ser isolada e purificada a partir de uma neoplasia de camundongo dotada de grande quantidade de membrana basal, o tumor EngelbrethHolm-Swarm (EHS) (TIMPL et al., 1979).

A laminina é uma proteína heterotrimérica composta por três cadeias $(\alpha, \beta$ e $\gamma)$, que se organizam formando uma estrutura cruciforme. Essa disposição dá origem a três braços curtos, e a um braço longo formado pelo entrelaçamento de porções de cada uma das três cadeias (MARTIN e TIMPL, 1987; MINER e YURCHENCO, 2004; AUMAILLEY et al., 2005). Através de fotomicrografias 
eletrônicas, observou-se que a laminina possui segmentos semelhantes a espetos, assim como domínios globulares (MARTIN e TIMPL, 1987; MINER e YURCHENCO, 2004).

A laminina apresenta isoformas resultantes da combinação de diferentes cadeias $\alpha, \beta$ e $\gamma$. Até o momento, já foram identificados cinco genes distintos para a cadeia $\alpha$, quatro para a $\beta$ e três para a cadeia $\gamma$, sendo que as cadeias $\alpha 2, \alpha 3$ e $\gamma 3$ podem ser também codificadas por "splicing" alternativo (COLOGNATO e YURCHENCO, 2000; BOSMAN e STAMENKOVIC, 2003; MINER e YURCHENCO, 2004). A união das diferentes cadeias $\alpha, \beta$ e $\gamma$ resultaria em 45 possíveis combinações heterotriméricas, sem considerar variantes de "splicing". Entretanto, o número real de combinações é bem inferior, devido a restrições de união entre algumas cadeias (COLOGNATO e YURCHENCO, 2000). Atualmente, a família das lamininas é constituída por 16 isoformas, mas provavelmente existem outras que ainda não foram isoladas (MALINDA e KLEINMAN, 1996; PONCE et al., 2001; MINER e YURCHENCO, 2004). As isoformas de laminina são sintetizadas por praticamente todas as células epiteliais, além de células musculares lisas, de tecido ósseo, de músculo cardíaco, nervosas, endoteliais e de medula óssea. Após a síntese, esta molécula se deposita principalmente, mas não exclusivamente, na membrana basal (BOSMAN e STAMENKOVIC, 2003).

Recentemente, Aumailley et al. (2005) propuseram uma nova classificação para as diferentes isoformas de laminina, que recebiam nomes de acordo com a ordem em que foram descobertas (laminina-1, laminina-2 e assim sucessivamente). Com exceção da laminina-1, era difícil relacionar uma determinada isoforma com as cadeias $\alpha, \beta$ e $\gamma$ pelas quais era formada. Foi então proposto que as isoformas da laminina fossem classificadas com uma numeração composta que representasse essas cadeias. Assim, a laminina-1, por exemplo, passaria então a ser chamada de laminina-111, já que possui cadeias $\alpha 1 \beta 1 \gamma 1$. Laminina-5, por sua vez, seria denominada laminina-332, por ser composta pelas cadeias $\alpha 3 \beta 3 \gamma 2$.

A tabela a seguir mostra as isoformas da laminina, suas cadeias e as integrinas com as quais se ligam, assim como suas classificações (BURGESON et al., 1994a; AUMAILLEY et al., 2005). 
Tabela 2.1 - Isoformas da laminina, suas respectivas cadeias e integrinas ligantes.

\begin{tabular}{l|l|l|l}
$\begin{array}{c}\text { Classificação } \\
\text { antiga }\end{array}$ & $\begin{array}{c}\text { Classificação } \\
\text { Nova }\end{array}$ & \multicolumn{1}{|c}{ Cadeias } & \multicolumn{1}{|c}{ Receptores (integrinas) } \\
\hline \hline Laminina-1 & 111 & $\alpha 1 \beta 1 \gamma 1$ & $\alpha 1 \beta 1, \alpha 2 \beta 1, \alpha 6 \beta 1, \alpha 6 \beta 4, \alpha 7 \beta 1$ \\
Laminina-2 & 211 & $\alpha 2 \beta 1 \gamma 1$ & $\alpha 1 \beta 1, \alpha 2 \beta 1, \alpha 3 \beta 1, \alpha 6 \beta 1, \alpha 6 \beta 4, \alpha 7 \beta 1$ \\
Laminina-3 & 121 & $\alpha 1 \beta 2 \gamma 1$ & ND \\
Laminina-4 & 221 & $\alpha 2 \beta 2 \gamma 1$ & Similar à laminina-2 \\
Laminina-5 & 332 & $\alpha 3 \beta 3 \gamma 2$ & $\alpha 3 \beta 1, \alpha 6 \beta 4, \alpha 6 \beta 1$ \\
Laminina-6 & 311 & $\alpha 3 \beta 1 \gamma 1$ & ND \\
Laminina-7 & 321 & $\alpha 3 \beta 2 \gamma 1$ & ND \\
Laminina-8 & 411 & $\alpha 4 \beta 1 \gamma 1$ & $\alpha 6 \beta 1$ \\
Laminina-9 & 421 & $\alpha 4 \beta 2 \gamma 1$ & ND \\
Laminina-10 & 511 & $\alpha 5 \beta 1 \gamma 1$ & $\alpha 3 \beta 1, \alpha 6 \beta 1$ \\
Laminina-11 & 521 & $\alpha 5 \beta 2 \gamma 1$ & $\alpha 3 \beta 1, \alpha 6 \beta 1$ \\
Laminina-12 & 213 & $\alpha 2 \beta 1 \gamma 3$ & ND \\
Laminina-13 & 323 & $\alpha 3 \beta 2 \gamma 3$ & ND \\
Laminina-14 & 423 & $\alpha 4 \beta 2 \gamma 3$ & ND \\
Laminina-15 & 523 & $\alpha 5 \beta 2 \gamma 3$ & ND \\
\hline
\end{tabular}

Fonte: (BURGESON et al., 1994b; KUTLESA et al., 2002; AUMAILLEY et al., 2005).

A laminina contribui fortemente para a organização supramolecular final da membrana basal, e neste contexto interage com ela mesma e com colágeno IV, nidogênio e proteoglicanas (MARTIN e TIMPL, 1987; MALINDA e KLEINMAN, 1996; COLOGNATO e YURCHENCO, 2000; BOSMAN e STAMENKOVIC, 2003; MINER e YURCHENCO, 2004). Além disso, parece estar relacionada com início da formação da matriz da membrana basal, já que é a primeira molécula a ser sintetizada durante o desenvolvimento embrionário (MALINDA e KLEINMAN, 1996; COLOGNATO e YURCHENCO, 2000). A importância da laminina é ainda reforçada pelo fato de sua ausência impedir a formação da membrana basal (YURCHENCO et al., 2004; YURCHENCO e WADSWORTH, 2004).

Além de funções estruturais, a laminina possui diversas atividades biológicas, que incluem promoção de adesão celular, espraiamento, migração, proliferação, crescimento de neuritos, metástase de tumores e secreção de protease (MARTIN e TIMPL, 1987; MALINDA e KLEINMAN, 1996; PONCE et al., 2001; BOSMAN e STAMENKOVIC, 2003). Algumas dessas atividades já foram correlacionadas a importantes eventos da progressão de neoplasias malignas, através de estudos in vitro e in vivo. 
Adesão de células epiteliais malignas à laminina foi a primeira atividade biológica demonstrada para essa proteína na progressão tumoral (MALINDA e KLEINMAN, 1996). Laminina também mostrou atividade quimiotática quando em solução, o que pode explicar sua habilidade em estimular movimentos celulares necessários aos processos de invasão e metástase (MARTIN e TIMPL, 1987; MALINDA e KLEINMAN, 1996). Essa molécula ainda é capaz de induzir fenótipo maligno. Pesquisas demonstraram que células cultivadas sobre laminina formam mais tumores in vivo do que células não aderentes ou células aderentes à fibronectina (TERRANOVA et al., 1984). Ainda, células tumorais co-injetadas com laminina em ratos atímicos promoveram aumento da formação de colônias metastáticas no pulmão (IWAMOTO et al., 1987).

A laminina, assim como outras moléculas da matriz extracelular, é capaz de regular atividades celulares e pode fornecer instruções para as células. Essas instruções não são estáticas, e aparecem de acordo com a necessidade da célula (SCHENK e QUARANTA, 2003). Dissecção bioquímica da laminina relatou que algumas de suas funções são específicas a porções dessa grande glicoproteína, demonstrando que diferentes partes da laminina exercem efeitos diferentes nas células (FAISAL KHAN et al., 2002). Estudos evidenciaram que pequenas sequências de aminoácidos derivadas da laminina são capazes de estimular funções biológicas. Essas sequências são conhecidas como peptídeos bioativos e algumas das funções que exercem não são as mesmas da proteína íntegra (SCHENK e QUARANTA, 2003; HANDSLEY e EDWARDS, 2005).

Por tal motivo, os efeitos da laminina não podem ser relacionados apenas a sua molécula como um todo, uma vez que possuem escondida em sua estrutura, diversos sítios ativos. Esses sítios podem não estar expostos na superfície da molécula na sua forma intacta, sendo por isso, denominados matricriptinas ou sítios matricrípticos. As matricriptinas podem ser encontradas em diversas proteínas da matriz extracelular (SCHENK e QUARANTA, 2003).

Os mecanismos que regulam a exposição de sítios matricrípticos representam uma etapa relevante no controle dos vários eventos biológicos promovidos pela MEC. Pelo menos cinco mecanismos vinculados à geração desses sítios já foram descritos, e todos envolvem modificação estrutural ou conformacional de moléculas da matriz: (1) degradação enzimática por ação proteolítica; (2) ligação heterotípica 
(adsorção) a outras moléculas, levando a mudança conformacional; (3) multimerização (organização de moléculas em arranjo), (4) forças mecânicas mediadas por células, e (5) denaturação (DAVIS et al., 2000; SCHENK e QUARANTA, 2003).

A hipótese mais aceita para explicar a existência de sítios matricrípticos é a de que provavelmente eles fazem parte de uma estratégia evolutiva para controlar diferentes atividades celulares. Dessa forma, determinadas instruções podem permanecer escondidas na molécula intacta até serem requeridas, não havendo necessidade de inibidores ou bloqueio de atividade que não foi requisitada em determinado momento (SCHENK e QUARANTA, 2003).

\subsubsection{Laminina-111 e peptídeos bioativos derivados AG73 e C16}

Como os peptídeos que estudamos nesse trabalho são derivados das cadeias $\alpha 1$ e $\gamma 1$ da laminina-111, faremos uma breve revisão sobre esta molécula.

Dentre todas as isoformas da laminina, a laminina-111 (antiga laminina-1, 900 kDa), formada pelas cadeias $\alpha 1$ (400 kDa), $\beta 1$ (200 kDa) e $\gamma 1$ (200 kDa) é a mais estudada e foi a primeira a ser identificada, estruturalmente analisada e sequenciada (TIMPL e BROWN, 1994; AUMAILLEY e SMYTH, 1998; EKBLOM et al., 1998; COLOGNATO e YURCHENCO, 2000).

A laminina-111 é considerada a mais importante nos estágios iniciais do desenvolvimento (TIMPL e BROWN, 1994; SASAKI et al., 2004). Experimentos mostraram que camundongos que não expressavam laminina-111 morriam logo após implantação do embrião, enquanto que na ausência de moléculas como perlecan, colágeno IV ou nidogênio, esta etapa transcorria normalmente (SASAKI et al., 2004).

O modelo estrutural proposto para a laminina-111 foi baseado na correlação entre análise química da proteína, observações em microscopia eletrônica e estudo de fragmentos proteolíticos purificados. Nesse modelo, as cadeias $\alpha 1, \beta 1$ e $\gamma 1$ dispõem-se como uma bobina enrolada sobre si mesma. A cadeia $\alpha 1$ possui três domínios globulares em sua porção amino-terminal, separados por repetições do tipo EGF (fator de crescimento epidermal). Na porção carbóxi-terminal existe um domínio tipo bobina e um grande domínio globular contendo 5 glóbulos. As cadeias 
$\beta 1$ e $\gamma 1$ são menores em relação a $\alpha$, contendo apenas dois domínios globulares e duas repetições tipo EGF na porção amino-terminal. Pontes dissulfeto unem as cadeias próximas ao domínio carbóxi-terminal, enquanto a porção amino-terminal permaneça livre (MINER e YURCHENCO, 2004; AUMAILLEY et al., 2005). As três cadeias que formam a laminina-111 apresentam três braços curtos, sendo que um possui $48 \mathrm{~nm}$ de comprimento e dois possuem $34 \mathrm{~nm}$. O braço longo tem $77 \mathrm{~nm}$ (AUMAILLEY e SMYTH, 1998).

A cadeia $\alpha 1$ da laminina-111 é a mais conhecida e estudada. É encontrada no blastocisto e em uma variedade de locais durante a embriogênese, mas está praticamente ausente nos tecidos adultos (EKBLOM et al., 1998; COLOGNATO e YURCHENCO, 2000; MINER e YURCHENCO, 2004). Virtanen et al. (2000) analisaram a distribuição da cadeia $\alpha 1$ em tecidos humanos adultos e embrionários, e observaram sua expressão nas membranas basais de rins e testículos, tanto no período de embriogênese quanto no adulto. Estes autores relatam ainda que a cadeia $\alpha 1$ foi encontrada nas membranas basais da tireóide, de glândulas salivar e mamária, do endométrio e de folículos capilares em desenvolvimento, mas não na membrana basal da epiderme adulta e trato digestório (VIRTANEN et al., 2000).

Já a cadeia $\gamma 1$ está presente na maioria das isoformas da laminina, exceto na laminina-332 (antiga laminina 5) (BURGESON et al., 1994a; NOMIZU et al., 1997a; EKBLOM et al., 1998; COLOGNATO e YURCHENCO, 2000; PONCE e KLEINMAN, 2003). Essa cadeia apresenta ligação com alta afinidade ao nidogênio, que está presente em todas as laminas basais. A interação ocorre através de domínios EGF"like" localizadas no braço curto da cadeia e parece ser particularmente interessante, uma vez que, anticorpos que bloqueiam a ligação mostraram inibir de maneira significativa a morfogênese de pulmão, glândula salivar e rim (EKBLOM, 1996; NOMIZU et al., 1997b; EKBLOM et al., 1998).

Além de seu papel no desenvolvimento, a laminina-111 também é uma molécula adesiva para a maioria dos tipos celulares, e ainda promove espraiamento, proliferação, crescimento de neuritos, metástase tumoral, angiogênese, secreção de protease e colagenase IV (MARTIN e TIMPL, 1987; KANEMOTO et al., 1990; POWELL e KLEINMAN, 1997; WEEKS et al., 1999; NOMIZU et al., 2000; 
KURATOMI et al., 2002; EKBLOM et al., 2003; PONCE et al., 2003; PONCE e KLEINMAN, 2003).

Células mioepiteliais derivadas de tecido glandular de mama normal atuam mantendo a correta polaridade celular através de sua habilidade em sintetizar laminina-111 (GUDJONSSON et al., 2002). Células derivadas de carcinomas parecem ser capazes de sintetizar, depositar e utilizar diferentes isoformas de laminina, como a 111 (PATARROYO et al., 2002; ZIOBER et al., 2006). Trabalho verificou que células derivadas de melanoma eram capazes de produzir e sintetizar laminina-111, e ainda que, essa molécula é capaz de promover migração dessas células (OIKAWA et al., 2010).

As várias atividades biológicas estimuladas pela laminina, tanto em células normais quanto neoplásicas, despertaram o interesse em estudar os diferentes sítios ativos da molécula. Para realizar esses estudos, foram utilizados clones de cadeias de laminina, seqüências de peptídeos correspondentes a vários domínios estruturais (fragmentos proteolíticos e peptídeos sintéticos) e anticorpos.

Para pesquisar sequências biologicamente ativas na molécula de laminina111, foram realizadas varreduras sistemáticas de seqüências, com posterior síntese de 560 peptídeos das três cadeias da laminina-111 ( $\alpha 1, \beta 1$ e $\gamma 1)$, sendo 208 peptídeos da cadeia $\alpha 1,187$ da cadeia $\beta 1$ e 165 da cadeia $\gamma 1$. Depois de sintetizados, os peptídeos foram testados quanto à sua capacidade de adesão. Dentre os 560 peptídeos, apenas 51 foram identificados como seqüências adesivas, sendo 25 da cadeia $\alpha 1,14$ da cadeia $\beta 1$ e 12 da cadeia $\gamma 1$ (NOMIZU et al., 1997a; NOMIZU et al., 1998; NOMIZU et al., 2000; NOMIZU et al., 2001).

Outro estudo avaliou especificamente o domínio globular da cadeia $\alpha 1$. Foram seqüenciados e sintetizados 113 peptídeos, dos quais 19 foram analisados quanto à capacidade de promover adesão e inibir espraiamento celular à laminina-111. Ao final, cinco peptídeos ativos foram identificados e em seguida testados em atividades biológicas adicionais (NOMIZU et al., 1995). Entre os peptídeos analisados AG73 (RKRLQVQLSIRT), localizado no quarto domínio globular (LG4), mostrou possuir a mais forte atividade adesiva, bem como efeito inibitório dose-dependente sobre 0 espraiamento celular à laminina. Este estudo demonstrou ainda que AG73 
provavelmente interage com receptores de superfície celular utilizando a seqüência ativa de aminoácidos LQVQLSIRT (NOMIZU et al., 1995).

Os efeitos de AG73 já foram testados em várias células e sistemas, tanto in vitro quanto in vivo (HOFFMAN et al., 1998; HOFFMAN et al., 2001; ENGBRING et al., 2002; IKEMOTO et al., 2006). Esse peptídeo promove adesão de vários tipos celulares (NOMIZU et al., 1995; NOMIZU et al., 1998) e está envolvido na diferenciação acinar de glândulas salivares através de interação com o receptor sindecana-1 (HOFFMAN et al., 1998; HOSOKAWA et al., 1999). Ainda em relação a glândulas salivares, AG73 inibe morfogênese por brotamento dessas estruturas (KADOYA et al., 1998; KADOYA e YAMASHINA, 2005). Ele ainda é capaz de estimular crescimento de neuritos (RICHARD et al., 1996; RIALAS et al., 2000), e secreção de MMPs em células neuronais PC12 (WEEKS et al., 1998).

AG73 também tem uma grande relevância em biologia tumoral (SONG et al., 1997; ENGBRING et al., 2002; SUZUKI et al., 2003; SUZUKI et al., 2005; MOCHIZUKI et al., 2007). Quando co-injetado com células de melanoma B16F10, esse peptídeo promoveu maior número de metástases em pulmões, no fígado e em tecido ósseo (SONG et al., 1997; KIM et al., 1998; ENGBRING et al., 2008).

Laminina-111 e AG73 co-injetados com células de tumor ovariano induziram aumento na taxa de crescimento tumoral e metástase. O peptídeo aumentou ainda a expressão de Mdm2 e Bcl2, genes relacionados à inibição de apoptose, nessas células (YOSHIDA et al., 2001). AG73 também promoveu metástases de células de carcinoma de mama MDA-231 em tecido ósseo (ENGBRING et al., 2008).

Adicionalmente, esse peptídeo também está relacionado a angiogênese em diferentes sistemas, como anéis aórticos, formação de tubo endotelial e membrana corioalantóica, e por isso pode ter aplicação terapêutica em injúrias isquêmicas (MOCHIZUKI et al., 2003). O uso de AG73 também já foi indicado em regeneração e engenharia tecidual, devido a seu potencial de promover adesão celular e formação de filopódia quando conjugado a membranas de quitosana (MOCHIZUKI et al., 2003; IKEMOTO et al., 2006; HOZUMI et al., 2009).

Nosso laboratório demonstrou que AG73 é capaz de regular a morfologia de células derivadas de neoplasias de glândula salivar (OLIVEIRA, 2004; GAMA-DE- 
SOUZA et al., 2008). Adicionalmente, esse peptídeo promoveu atividade de adesão e estimulou secreção de proteases através da interação com os receptores sindecana-1 e integrina $\beta 1$ em linhagens celulares derivadas de carcinoma adenóide cístico e mioepitelioma humanos (GAMA-DE-SOUZA et al., 2008).

Outro peptídeo da cadeia $\alpha 1$ é o SIKVAV, dentre os peptídeos derivados da laminina-111 é o mais conhecido e estudado. Está localizado no final do braço longo da cadeia $\alpha 1$, logo acima do domínio globular (TASHIRO et al., 1989). SIKVAV estimula atividades biológicas como adesão, migração, crescimento de neuritos e indução de metástase experimental (TASHIRO et al., 1989; KANEMOTO et al., 1990; GRANT et al., 1992; NOMIZU et al., 1992).

Trabalho envolvendo o peptídeo SIKVAV e células derivadas de carcinoma adenóide cístico humano (células CAC2) demonstrou que, os peptídeos induzem a formação de espaços pseudocísticos quando as células são crescidas em preparados tridimensionais e que esse fenômeno pode estar relacionado com a secreção de MMPs (FREITAS e JAEGER, 2002). Em um estudo mais recente foi verificado que o SIKVAV estimula, de maneira dose-dependente, a secreção de MMP2 e MMP9 nas células CAC2. Além disso, a regulação dessa atividade pode parece envolver receptores do tipo integrinas $\alpha 6, \alpha 3$ e $\beta 1$ e a via ERK1/2 (FREITAS et al., 2007).

$\mathrm{Na}$ cadeia $\beta 1$, a sequência YIGSR é capaz de promover adesão celular e migração, bem como inibir angiogênese e metástases tumorais (GRAF et al., 1987; IWAMOTO et al., 1987; MORAIS FREITAS et al., 2007). As sequências PDSGR e F9 (RYVVLPR), localizadas na mesma cadeia, também promovem adesão celular (CHARONIS et al., 1988; SKUBITZ et al., 1990).

Em relação à cadeia $\gamma 1$ da laminina, embora esteja presente na maioria das isoformas, pouco se sabe sobre suas funções e sítios biologicamente ativos.

Nomizu et al. (1997) realizaram varreduras sistemáticas de sequências e ensaios de adesão e revelaram 20 sequências ativas dessa cadeia. Dentre essas sequências, foram encontrados quatro peptídeos com forte atividade adesiva e avaliados quanto á capacidade de estimular outras atividades biológicas. O peptídeo C16 (KAFDITYVRLKF), presente no primeiro domínio globular da cadeia $\gamma 1$, foi 
identificado como uma dessas sequências ativas e mostrou ter forte atividade adesiva em células de fibrossarcoma (HT1080) e melanoma (B16-F10) (NOMIZU et al., 1997a). O trabalho revelou ainda que os aminoácidos YVRL são críticos para que $\mathrm{C} 16$ possa promover seus efeitos.

Foram ainda descritas como atividades desse peptídeo promoção de adesão em células HSG e endoteliais, efeito na formação de tubos semelhantes a capilares, estimulação de crescimento de neuritos, diminuição na formação e diferenciação de ácinos, bloqueio de adesão celular a diferentes substratos, como a laminina-111, colágeno-I e fibronectina. Esse último efeito sugere que $\mathrm{C} 16$ possa agir via receptor comum a esses substratos, por exemplo, receptor do tipo integrina (NOMIZU et al., 1997a; PONCE et al., 1999; RIALAS et al., 2000; PONCE et al., 2001).

Trabalhos mostraram que C16 representa um potente sítio angiogênico da cadeia $\gamma 1$ (PONCE et al., 1999; PONCE et al., 2001; PONCE e KLEINMAN, 2003). Além de promover adesão de células endoteliais, foi capaz de estimular brotamento in vivo dessas células a partir de anéis aórticos. Ensaios realizados in vivo confirmaram o efeito angiogênico do $\mathrm{C} 16$. Contudo, o peptídeo não foi capaz de estimular migração e proliferação de células endoteliais (PONCE et al., 2003).

A degradação da matriz extracelular representa uma das primeiras etapas durante o processo de invasão tumoral, cicatrização, e remodelação tecidual (GHOSH e STACK, 2000; SCHENK e QUARANTA, 2003; MOTT e WERB, 2004). A laminina, quanto intacta, não possui efeito angiogênico, entretanto, durante efeitos de degradação da matriz, ela sofre clivagem e isso permite que sequências ativas se tornem expostas, induzindo uma resposta angiogênica (PONCE e KLEINMAN, 2003).

Trabalho realizado por Kuratomi et al. (2002) mostrou que o peptídeo C16 induziu aumento significativo de metástase pulmonar de células de melanoma (B16F10). Além disso, o peptídeo estimulou migração e secreção de MMP9 nessas células. Embora os mecanismos envolvidos nesses processos não tenham sido descritos pelos autores, eles acreditam que C16 desempenhe papel em várias etapas da metástase, como adesão, migração, invasão e geração de aporte sanguíneo. Contudo, C16 não parece estimular proliferação. 
A capacidade do $\mathrm{C} 16$ em estimular migração já foi demonstrada em células derivadas de melanoma (LUGASSY et al., 2007). Nesse trabalho, foi verificado que o peptídeo C16 aumenta a migração extra-vascular angiotrópica de melanomas. Com isso, os autores sugeriram que o peptídeo pode se tornar um alvo molecular na prevenção de metástase tumoral em melanomas. Também foi verificado efeito do C16 no processo de cicatrização in vivo (MALINDA et al., 2008). Os resultados obtidos pelos autores demonstraram que o peptídeo estimulou migração de fibroblastos, contração de bordas de ferida, reepitelialização e angiogênese. Como proposta final, os autores acreditam que o C16 tem potencial para ser desenvolvido como um novo agente terapêutico nos processos de cicatrização.

Dados de nosso laboratório também sugerem que C16 estimula migração, invasão e secreção de protease em células de carcinoma adenóide cístico através de integrinas $\alpha 5 \beta 1$ e $\alpha v \beta 3$ e vias de sinalização ERK e AKT (GAMA-DE-SOUZA, 2008).

\subsection{Invadopódios}

O processo de metástase, que consiste na disseminação das células do tumor primário para tecidos subjacentes (sítios secundários do tumor), ainda é um dos eventos patológicos mais ameaçadores. Devido a isso, nos últimos anos, esforços têm sido realizados na tentativa de compreender os mecanismos moleculares que ocorrem nas etapas da metástase. Dentre essas etapas estão, (1) separação das células tumorais do tumor primário, (2) invasão para tecidos subjacentes, (3) invasão para vasos sanguíneos e linfáticos, (4) disseminação pelos vasos sanguíneos e/ou pelo sistema linfático e finalmente, (5) extravasamento e crescimento do tumor em um sítio secundário. Cada uma das etapas envolve um programa molecular diferente no qual, as propriedades do citoesqueleto são essenciais para a modulação das atividades de adesão e migração das células tumorais e para a disseminação o tumor (CHAMBERS et al., 2002; YILMAZ e CHRISTOFORI, 2009).

Para se desprender do tumor primário e invadir para tecidos subjacentes, células tumorais devem perder contatos célula-célula, remodelar sítios de adesão célula-matriz e seguir quimioatrativos atravessando a matriz extracelular (MEC) através da secreção de proteases. Esses processos são observados em condições 
fisiológicas, como por exemplo, na gastrulação, no qual, células epiteliais diferenciadas retornam a um fenótipo mais indiferenciado para se movimentar até sítios distantes e então, se re-diferenciam para formar uma nova estrutura. Esse fenômeno temporário e reversível é conhecido como transição epitélio-mesênquima (TEM), e têm recebido atenção na investigação dos processos de migração, invasão e metástase de células tumorais (GRUNERT et al., 2003; THIERY e SLEEMAN, 2006).

Nos últimos anos, protrusões ricas em actina que possuem atividade proteolítica da MEC, têm recebido particular atenção no contexto da invasão celular tumoral. Essas protrusões são denominadas invadopódios (CHEN et al., 1985; CHEN, 1989; CONDEELIS e SEGALL, 2003; WEAVER, 2006). O processo de TEM leva a um aumento de mobilidade e invasão nas células epiteliais através da perda de adesão célula-célula, modulação de adesão célula-matriz e indução de secreção de proteases que degradam a matriz. Dessa forma, pode-se dizer que TEM pode provocar a formação de invadopódios. Embora ainda não existam evidências experimentais que relacionem TEM com formação de invadopódios, já foi identificada uma grande variedade de moléculas comumente importantes para a ativiação ambos os processos (FRAME, 2004; YAMAGUCHI et al., 2005; BOWDEN et al., 2006; VARON et al., 2006; LO et al., 2007; WEBB et al., 2007). Dentre essas moléculas estão os fatores de crescimento EGF, HGF, PDGF, e TGF $\beta$, e a Src tirosina quinase. Esses dados sugerem fortemente que a formação de invadopódios pode funcionar como um guia no processo de TEM (AYALA et al., 2006).

Além da sua importância na invasão de tecidos subjacentes e de vasos sanguíneos e linfáticos, os invadopódios também participam do extravasamento para sítios secundários do tumor. Um estudo verificou que as quimiocinas S100A8 e S100A9, produzidas por células endoteliais no nicho pré-metastático, contribuem para a invasão de células tumorais circulantes em sítios secundários do tumor através da formação de invadopódios (RAFII e LYDEN, 2006).

Os invadopódios são estruturas formadas em células invasivas que possuem atividade de degradação. São protrusões de membrana que se originam na região ventral da membrana, estendendo-se verticalmente para a MEC (CHEN et al., 1985; CHEN, 1989; CONDEELIS e SEGALL, 2003; WEAVER, 2006). São enriquecidos com filamentos de actina e também com proteínas associadas, como proteínas de 
adesão, proteases de matriz e moléculas sinalizadoras que regulam o citoesqueleto de actina e a remodelação da membrana (BUCCIONE et al., 2004). Essas protrusões, formadas na região ventral da membrana aderente a matriz, podem medir de 0,1 a 0,8 $\mu \mathrm{m}$ em diâmetro e alcançar comprimento superior a $2 \mu \mathrm{m}$ (CHEN, 1989; BOWDEN et al., 1999). Estudos de microscopia eletrônica demonstram os invadopódios em sítios de invasão tumoral como estruturas complexas contendo múltiplas protrusões invadopodiais delgadas. Essas protrusões são verificadas como invaginações de membrana próximas ao complexo de Golgi com 0,8 $\mu \mathrm{m}$ de largura e $2 \mu \mathrm{m}$ de profundidade (BALDASSARRE et al., 2003).

Invadopódios são considerados uma forma transformada de podossomos. Os podossomos por sua vez, são formados por células normais que possuem alta atividade migratória como macrófagos, células dendríticas, osteoclastos e células endoteliais e do músculo liso ativadas. Através de análise de imagens obtidas por microscopia eletrônica de transmissão, os podossomos foram descritos como sítios de adesão ao substrato que correspondem a protrusões curtas da superfície ventral da membrana. Essas protrusões são formadas na porção apical e representariam o "pé" da célula (TARONE et al., 1985). Os podossomos se apresentam como estruturas arredondadas, com diâmetro aproximado de 0.5 a $1.0 \mu \mathrm{m}$ tendo ao centro actina circundada por estrutura semelhante a anel, formada por proteínas do citoesqueleto como vinculina, talina e paxilina (LINDER e AEPFELBACHER, 2003; LINDER e KOPP, 2005; LINDER, 2007). Os contatos focais são estruturas lineares ricas em filamentos de actina. No entanto não são arredondados nem exibem a estrutura central de actina que caracteríza os podossomos. Isso permite clara distinção entre podossomos e contatos focais como componentes diversos de contato celula-substrato (LINDER e AEPFELBACHER, 2003; BUCCIONE et al., 2004). A função exata dos podossomos ainda não foi muito bem elucidada, no entanto, essas estruturas são formadas quando as células precisam degradar junções aderentes e matriz de maneira concomitante. Um exemplo disso é quando células do sistema imune, como monócitos e células dendríticas, precisam migrar através dos tecidos, ou também durante a reabsorção óssea (SALTEL et al., 2004).

Embora podossomos e invadopódios possuam muitos componentes moleculares em comum, não está esclarecido se eles são estruturas distintas ou se representam uma mesma estrutura, transitoriamente desenvolvida em diferentes 
fases da invasão celular (WEBB et al., 2007). No entanto, estudo recente realizado com microscopia TIRF (Reflexão Fluorescente Total Interna) mostra que a estrutura de podossomos e invadopódios é distinta. Nesse estudo, os invadopódios foram verificados como extensões filamentosas compostas por cortactina que formam superestruturas invasivas, o mesmo não foi verificado nos podossomos, que não formaram nenhum tipo de protrusão de membrana filamentosa (ARTYM et al., 2011).

Os invadopódios foram descobertos em fibroblastos transformados pelo protooncogene viral Src, que codifica um tipo de tirosina quinase constitutivamente ativa. Células transformadas por Src crescidas sobre fibronectina formaram proeminentes protrusões ventrais com propriedades de adesão e degradação (CHEN et al., 1985; TARONE et al., 1985). Posteriormente, os invadopódios foram também identificados em linhagens celulares derivadas de tumores como melanoma, mama, glioma, e de tumores cabeça e pescoço (MUELLER et al., 1999; BALDASSARRE et al., 2003; ANGERS-LOUSTAU et al., 2004; HASHIMOTO et al., 2004; LORENZ et al., 2004; TAGUE et al., 2004; SEALS et al., 2005; ARTYM et al., 2006; CLARK et al., 2007; NASCIMENTO et al., 2009).

Estudos in vitro são utilizados para detectar a atividade de invadopódios. O ensaio utilizado é conhecido como ensaio de degradação da matriz fluorescente (CHEN et al., 1985; ARTYM et al., 2006; YAMAGUCHI et al., 2006). Nesse ensaio, células são crescidas sobre lamínulas cobertas com substratos nativos de proteínas da MEC conjugados a fluorocromos (exemplo fibronectina conjugada a fluoresceína). Essas proteínas podem ser substituídas por gelatina conjugada a fluorocromos. A atividade de degradação dos invadopódios é verificada por regiões com ausência de fluorescência, ou seja, áreas escuras no substrato fluorescente que são detectadas por microscopia de confocal. Co-marcação das células por alguns marcadores de invadopódios (como cortactina, F-actina, fosfotirosina) detectam, de maneira mais crítica, informação sobre estágios de formação e atividade funcional dos invadopódios (CHEN et al., 1985; ARTYM et al., 2006; BOWDEN et al., 2006).

Artym et al. (2006) propuseram um modelo dos estágios de formação, organização e função dos invadopódios. Esses estudos foram realizados em células derivadas de tumor maligno de mama (MDA-MD-231) transfectadas com vetores fluorescentes para as proteínas cortactina e MT1-MMP e plaqueadas sobre 
substrato de gelatina fluorescente. A análise em tempo real da distribuição das proteínas cortactina e MT1-MMP identificou quatro estágios de maturação dos invadopódios: (1) localização de cortactina na região ventral da célula em contato com a matriz, (2) recrutamento de uma metaloprotease de matriz tipo 1 (MT1-MMP) para essas regiões, (3) o aparecimento de focos de degradação na matriz circujacente e (4) a dissociação da proteína cortactina desses sítios.

Embora a maioria dos estudos envolva as proteínas cortactina e MT1-MMP, sabe-se que uma grande variedade de proteínas está associada ao invadopódio, incluindo proteínas de adesão, transdução de sinal, regulação de actina, proteólise da MEC e dinâmica de membrana. Essas proteínas podem ser divididas em quatro grupos de acordo com sua função e localização nos invadopódios (BUCCIONE et al., 2004).

O primeiro grupo é considerado como máquina motora para o funcionamento do invadopódio e inclui a actina e reguladores de sua polimerização (WANG et al., 2005). Dentre eles estão Arp2/3, N-WASP, Cdc42, Nck, cofilina, proteínas de vesículas encapadas, cortactina e dinamina. O segundo grupo inclui as integrinas, proteínas de adesão que modulam a interação dos invadopódios com a MEC. O terceiro grupo compreende proteínas sinalizadoras que regulam o citoesqueleto de actina e a remodelação da membrana (tirosina quinases e GTPases Ras). Proteases de membrana que modulam a degradação da MEC em sítios funcionais dos invadopódios constituem o quarto grupo. Fazem parte dele MT1-MMP, MMP-2 e MMP-9 (MONSKY et al., 1993; MONSKY et al., 1994; NAKAHARA et al., 1997; CHEN e WANG, 1999; DERYUGINA et al., 2001a; ARTYM et al., 2006; CLARK e WEAVER, 2008).

A seguir, serão abordadas de maneira mais específica, moléculas relacionadas aos invadopódios que foram estudadas nesse trabalho: cortactina, MT1-MMP.

A cortactina é uma proteína associada à actina e possui diversas funções celulares (WEED e PARSONS, 2001; DALY, 2004). Recebeu essa denominação, devido a sua localização na região cortical da actina (WU e PARSONS, 1993). Com relação a sua estrutura, a cortactina possui três regiões de interesse, a porção $\mathrm{N}$ terminal, a região de domínios repetitivos, e a porção C-terminal, rica em prolina e domínios homólogos à Src (SH3). A porção N-terminal está ligada ao complexo 
Arp2/3 que promove a formação e estabilização dos ramos de actina (WEAVER et al., 2001). A porção repetitiva é responsável pela ligação da cortactina com a actina. Já a porção $\mathrm{N}$-terminal é conhecida como a porção reguladora da molécula. As regiões ricas em prolina possuem diversos sítios de fosforilação para quinases e a região SH3 se conecta a diferentes alvos e promove ligação entre receptores transmembrana específicos e o citoesqueleto de actina (MARTINEZ-QUILES et al., 2004).

A cortactina é codificada pelo oncogene EMS1 localizado no cromossomo 11q13. Uma superexpressão dessa proteína é observada em diversos tumores incluindo de mama, cabeça e pescoço e está relacionada com invasão e prognóstico ruim da doença (DALY, 2004). Estudos in vitro verificaram que a cortactina aumenta a atividade de migração e invasão em células de fibrossarcoma e outros tipos celulares (PATEL et al., 1998; BRYCE et al., 2005; ROTHSCHILD et al., 2006).

Diversas proteínas-chave para os invadopódios estão ligadas á cortactina como N-WASP, dinamina e Src quinase, sugerindo que a cortactina tem função de arcabouço nos invadopódios (WEAVER, 2006). Dentro desse contexto, mutações nos sítios de fosforilação da porção C-terminal da cortactina tem efeitos drásticos no número e na função dos invadopódios (WEBB et al., 2007; AYALA et al., 2008).

Diversos estudos indicam que a cortactina têm papel estrutural nos invadopódios. Estudos realizados em células de músculo liso sugerem que o domínio SH3 da cortactina direciona a proteína para a formação de podossomos (WEBB et al., 2006). Acredita-se que o mesmo ocorra nos invadopódios. Além disso, o domínio SH3 da cortactina se liga a N-WASP podendo direcionar a cortactina para os invadopódios. Ambas as proteínas, N-WASP e cortactina podem ativar 0 complexo Arp2/3 para se ligar a F-actina, promovendo sítios de nucleação importantes na síntese de novos filamentos de actina. A cortactina se liga a F-actina e ao Arp2/3 simultaneamente inibindo a despolimerização da actina. Essa ligação simultânea pode estabilizar estruturas de actina já existentes e direcionar a organização de novas ramificações (WEAVER et al., 2001). Essa atividade de cortactina aumenta a persistência de lamelipódios e direciona a migração podendo ter efeito similar na persistência do invadopódios (BRYCE et al., 2005).

Como já mencionado, o estudo de Artym et al. (2006) verificou que o acúmulo de cortactina em regiões da membrana celular é um estímulo para o recrutamento 
de MT1-MMP nessas regiões e subsequente degradação da matriz circunjacente. Esse fenômeno trata-se de um dos estágios de formação do invadopódios que foi denominado como "pré-invadopódio". Dessa forma, a cortactina é importante não só na organização estrutural dos invadopódios, mas também teria um papel na regulação do tráfego de membrana, participando da atividade de degradação dessas protrusões. Outro estudo verificou que protrusões celulares que apresentavam colocalização de cortactina e fosfotirosina, pertenciam ao grupo dos invadopódios que ativamente degradavam a MEC (BOWDEN et al., 2006). Isso indica que sinalização de fosfotirosina e cortactina são importantes para a distribuição e ativação de proteases nos invadopódios. Além disso, dados sugerem que a cortactina é essencial para o tráfego de proteases dos invadopódios como MT1-MMP, MMP2 e MMP9 em células de carcinoma epidermóide de cabeça e pescoço (CLARK et al., 2007; CLARK e WEAVER, 2008).

Diversas metaloproteases e serina proteases estão relacionadas aos invadopódios e contribuem para a atividade de degradação de células tumorais. As metaloproteases de matriz constituem uma família de aproximadamente 25 endopeptidases (em humanos) dependentes de zinco $\left(\mathrm{Zn}^{2+}\right)$ que degradam componentes da MEC. São classificadas de acordo com a especificidade de substrato ou ainda, de acordo com sua localização na célula, por exemplo, colagenases, gelatinases, estromelisinas e metaloelastases, ou MMPs de membrana (MT-MMPs).

Diferente do que ocorre com as MMPs, as MT-MMPs não são secretadas para o meio extracelular e ficam ligadas a membrana das células. Todas as MMPs possuem uma estrutura conservada em sua composição que consiste de: um peptídeo sinal, um pró-peptídeo e um domínio catalítico. Algumas MMPs também possuem um domínio de hemopexina (HPX) que contribui para o reconhecimento e degradação do substrato, bem como para as interações proteína-proteína (CAO et al., 2004; SUENAGA et al., 2005; ITOH et al., 2008).

MMPs são produzidas como zimogênios (pró-enzimas) e necessitam de clivagem proteolítica para sua ativação (EGEBLAD e WERB, 2002). No caso da MT1-MMP, a pró-MT1-MMP ( 64 kDa) é convertida na forma ativa da enzima ( 55 $\mathrm{kDa}$ ) pela furina na rede do trans-Golgi (TGN) antes de chegar a membrana plasmática (YANA e WEISS, 2000; MAZZONE et al., 2004). Já ativação das MMPs 
secretadas, pró-MMP-2 e pró-MMP-13, é mediada por um complexo formado por um homodímero de MT1-MMP e uma molécula única de TIMP-2 (um inibidor natural de MMPs) . TIMP-2 se liga ao domínio catalítico de uma das moléculas de MT1-MMP e ao domínio de hemopexina da pró-MMP-2. Isso facilita então a clivagem e ativação da pró-MMP- 2 pela outra molécula de MT1-MMP do complexo (STRONGIN et al., 1995; BUTLER et al., 1998; KINOSHITA et al., 1998).

Além da ativação da pró-MMP-2 e da pró-MMP-13, a MT1-MMP também pode clivar componentes da MEC como os colágenos tipo I, II, III e IV, gelatina, lamininas, 111 e 332, fibronectina, vitronectina, agrecana e fibrina, e proteínas de membrana como CD44, integrinas $\alpha \mathrm{v}$ e sindecana 1 (HOTARY et al., 2006; OVERALL e DEAN, 2006).

O interesse no estudo das MMPs aumentou devido as observação de que essas enzimas estavam relacionadas com algumas doenças, incluindo o câncer (DERYUGINA e QUIGLEY, 2006). Estudo retrospectivo realizado com amostras de pacientes com câncer revelou que a expressão da MT1-MMP e das MMPs 1, 2, 3, 7, 9 e 13, está associada com progressão tumoral e metástase podendo ser considerada um importante fator prognóstico (HOFMANN et al., 2005; DERYUGINA e QUIGLEY, 2006). Além disso, de maneira interessante, MT1-MMP e MMP-2 são verificadas na fronte de invasão tumoral (UENO et al., 1997; HOFMANN et al., 2003). MT1-MMP, MMP-2 e MMP-9 também são encontradas nos invadopódios e são importantes na função dessas protrusões (MONSKY et al., 1993; MONSKY et al., 1994; NAKAHARA et al., 1997; CHEN e WANG, 1999; DERYUGINA et al., 2001b; ARTYM et al., 2006; CLARK e WEAVER, 2008).

Em células de melanoma, a expressão de MT1-MMP aumenta a invasão celular através da estimulação de invadopódios (NAKAHARA et al., 1997). Como já mencionado, o acúmulo de MT1-MMP nos invadopódios de células derivadas de tumor de mama estimulou a degradação da matriz (ARTYM et al., 2006). O mesmo estudo mostrou que células derivadas de tumor de mama inibidas com RNAi para MT1-MMP ou tratadas com inibidores de TIMP-2 continuavam formando invadopódios, observados pelo acúmulo de cortactina na porção ventral da membrana. No entanto, a atividade de degradação dos invadopódios dessas células foi drasticamente inibida (ARTYM et al., 2006). Estudo realizado em outro tipo celular demonstrou diminuição significante na formação de invadopódios em células 
tratadas com inibidores de MMP, isso sugere que a degradação da matriz pelas MMPs pode gerar um mecanismo de retroalimentação positiva, aumentando a atividade de invadopódios (CLARK et al., 2007).

É importante ressaltar que já detectamos ambas as proteínas mencionadas, cortactina e MT1-MMP, nos invadopódios das células derivadas de carcinoma adenóide cístico (células CAC2) plaqueadas sobre Matrigel (NASCIMENTO et al., 2009). Nesse estudo, verificamos a colocalização dessas proteínas nas áreas de degradação do substrato. 


\section{PROPOSIÇÃO}

Esse trabalho tem como objetivo analisar a atividade de invadopódio induzida pelos peptídeos da laminina-111, AG73 e C16, em células derivadas de carcinoma adenóide cístico humano. Adicionamente, buscamos por mecanismos regulatórios envolvidos nos efeitos desses peptídeos. O estudo foi envolveu as seguintes etapas:

1) Efeitos dos peptídeos bioativos $A G 73$ e C16 na atividade de invadopódio em células de carcinoma adenóide cístico (células CAC2).

2) Análise de integrina- $\beta 1$ como possível molécula que transduziria os sinais gerados pelos peptídeos AG73 e C16 em células CAC2. Esses sinais estariam envolvidos na atividade biológica de invasão celular através da estimulação de invadopódios.

3) Possíveis vias de sinalização desencadeadas pelos peptídeos AG73 e C16 em células CAC2. Essas vias estariam envolvidas na atividade invasiva dessas células pela estimulação de invadopódios. 


\section{MATERIAL E MÉTODOS}

O presente trabalho não envolveu manipulação direta nem de seres humanos e nem de animais, e foi aprovado pelo comitê de ética e pesquisa (CEP-ICB) em 21 de setembro de 2010 , no parecer 420/20.

\subsection{Detecção de proteínas do invadopódio no Carcinoma adenóide cístico in vivo}

\subsubsection{Imunohistoquímica}

Detectamos a expressão das proteínas cortactina e MT1-MMP in vivo no carcinoma adenóide cístico. Cinco amostras de carcinoma adenóide cístico oral humano, fixadas em $4 \%$ parafolmaldeído e incluídas em parafina, foram selecionadas de arquivo pertencente ao nosso Laboratório. Cortes histológicos dessas amostras ( $3 \mu \mathrm{m}$ de espessura) foram montados em lâminas cobertas por 3aminopropiltrietoxi-silano (Sigma) e estudados por imunohistoquímica. Os cortes foram desparafinados em xilol e hidratados em bateria crescente de etanol $(100 \%$, $90 \%$ e $80 \%$ ). Atividade de peroxidase endógena foi inibida por incubação dos cortes com $3 \% \mathrm{H}_{2} \mathrm{O}^{2}$ em metanol por 20 minutos. Em seguida, foi realizada recuperação antigênica em câmara de pressão Pascal (Dako, Cytomation, Carpinteria, CA, USA) por 30 segundos a $125 \stackrel{\circ}{\circ}$, utilizando tampão de citrato (10 mM ácido cítrico, 0,05\% Tween 20, pH 6). Os cortes foram então bloqueados com solução de $1 \%$ de albumina do soro bovino (BSA, Sigma) em PBS por 1 hora. Para detecção de cortactina foi utilizado anticorpo produzido em coelho (clone H-191, Santa Cruz). MT1-MMP foi detectada utilizando anticorpo monoclonal gerado em camundongo (clone 114-6G6, Chemicon). Os anticorpos primários foram diluídos 1/50 em PBS, e aplicados sobre os cortes por 1 hora em câmara úmida. Após lavagem com PBS, lâminas foram submetidas ao sistema de detecção Envision Plus conjugado com polímero de peroxidase anti-coelho ou anti-camundongo (Dako) em câmara úmida por 20 minutos. Diaminobenzidina (Dako) foi utilizada como cromógeno e os cortes histológicos foram contra-corados com hematoxilina de Mayer (Sigma). Substituição dos anticorpos primários por soro não-imune serviu como controle negativo. 


\subsection{Peptídeos bioativos da laminina}

Peptídeos da laminina-111 foram avaliados quanto à capacidade de estimular a atividade de invadopódios. Os peptídeos e peptídeos "scrambled" (peptídeos AG73 e C16 com sequências de aminoácidos embaralhadas e que, portanto, não possuem atividade biológica) foram obtidos da empresa EZ Biolab (Westfield, IN, USA). Os peptídeos possuem grau de pureza de 98\% (RP-HPLC) e peso molecular confirmado por espectrometria de massa. Os peptídeos "scrambled" serão mencionados no texto e nas figuras como AG73SX e C16SX. A tabela a seguir identifica os peptídeos e seus controles "scrambled", mencionando também sua sequência, cadeia e isoforma da laminina a que estão relacionados.

Tabela 4.1 - Peptídeos derivados da laminina-111 e seus controles peptídeos "scrambled" que foram utilizados no presente trabalho. A tabela demonstra sequência de aminoácidos, cadeia e isoforma da laminina a que os peptídeos estão relacionados.

\begin{tabular}{c|c|c|c|c|c}
\hline Peptídeo & Seqüência & "scrambled” & $\begin{array}{c}\text { Sequência } \\
\text { "scrambled” }\end{array}$ & Cadeia & Laminina \\
\hline AG73 & RKRLQVQLSIRT & AG73SX & RTLRIKQSVRLQ & $\alpha 1$ & 111 \\
C16 & KAFDITYVRLKF & C16SX & FKLRVYTIDFAK & $\gamma 1$ & 111 \\
\hline
\end{tabular}

\subsection{Papel dos peptídeos AG73 e C16 na atividade de invadopódio da linhagem celular CAC2}

\subsubsection{Cultura da linhagem celular CAC2}

Linhagem celular derivada de carcinoma adenóide cístico humano foi cultivada em meio de Eagle modificado por Dulbecco (DMEM - Sigma Chemical Co, St Louis, MO, USA), suplementado com $10 \%$ de soro fetal bovino (SBF). As células foram mantidas em frascos de $25 \mathrm{~cm}^{2}$ a $37{ }^{\circ} \mathrm{C}$, em atmosfera úmida contendo $5 \% \mathrm{CO}_{2}$. A obtenção e caracterização da linhagem CAC2 foram descritas em trabalho anterior (FREITAS e JAEGER, 2002).

Toda a manipulação foi realizada em capela de fluxo-laminar. Seu crescimento foi monitorado diariamente em microscópio invertido de contraste de fase. Meio de cultura foi trocado a cada 2 ou 3 dias conforme o metabolismo celular, e ao atingir subconfluência, células eram subcultivadas. Amostras representativas da cultura foram congeladas e mantidas em nitrogênio líquido, crio-protegidas com $5-10 \%$ de dimetil sulfóxido (DMSO-Sigma). 
4.3.2 Preparação de substrato para ensaio de degradação de substrato fluorescente

Utilizamos ensaio de degradação de substrato fluorescente para determinação in situ da atividade de degradação de invadopódios na linhagem celular derivada de carcinoma adenóide cístico (células CAC2). Como algumas MMPs são gelatinases e estão presentes nos invadopódios, esse tipo de ensaio permite a análise focal da atividade de degradação de invadopódio de determinada linhagem celular (ARTYM et al., 2006). Nesse ensaio, observamos os invadopódios pela presença de prolongamentos celulares (por exemplo, pela marcação de actina) que coincidem com focos de degradação (áreas escuras) no substrato fluorescente (gelatina-FITC). No presente estudo, utilizamos como substrato, uma mistura de 1) gelatina estéril do tipo $B$ na concentração de $0,2 \%$ (Sigma) e 2) gelatina conjugada a fluoresceína (gelatina-FITC, Invitrogen Co., Carlsbad, CA, USA) na proporção de 8/1. Para analisar a atividade de degradação sobre o substrato de gelatina, é necessário que o substrato seja tratado com reagentes que promovam a formação de ligações cruzadas. Para tanto, lamínulas de vidro devidamente esterilizadas (13 $\mathrm{mm}$ de diâmetro) foram inicialmente cobertas com poli-lisina por 20 minutos à temperatura ambiente, lavadas em PBS e então tratadas com glutaraldeído $0,5 \%$ por 15 minutos. Após três lavagens de 5 minutos em solução de PBS, as lamínulas foram invertidas sobre uma gota $(40 \mu \mathrm{l})$ da mistura de gelatina tipo $\mathrm{B}$ e gelatina-FITC (8:1), e incubadas por 10 minutos à temperatura ambiente. Os grupos residuais reativos presentes no glutaraldeído foram removidos por borohidreto de sódio ( 5 $\mathrm{mg} / \mathrm{ml}$ ) por 15 minutos. Após esse período, as lamínulas passaram por mais três lavagens de 5 minutos em PBS, ficando prontas para serem utilizadas no ensaio de degradação de substrato fluorescente.

\subsubsection{Ensaio de degradação de substrato fluorescente e detecção de invadopódios em células tratadas por peptídeos da laminina}

Para avaliar a capacidade dos peptídeos da laminina em estimular a atividade dos invadopódios nas células CAC2, células plaqueadas sobre o substrato de gelatina-FITC foram tratadas pelos peptídeos AG73 e C16. Para tanto, primeiramente, foi realizada a tripsinização das células, e após isso, uma quantidade de $2 \times 10^{4}$ células $/ \mathrm{ml}$ foi plaqueada sobre o substrato fluorescente na presença de DMEM com $0,5 \%$ de SBF. As células foram mantidas nessas condições por 1 hora, 
para que ocorresse adesão inicial das mesmas ao substrato. Após esse período, os peptídeos AG73 ou C16 foram então acrescidos no meio de cultura (DMEM com $0,5 \%$ de SBF) na concentração de $50 \mu \mathrm{g} / \mathrm{ml}$. As amostras foram mantidas nessas condições "overnight". Células tratadas por peptídeos "scrambled" (AG73SX ou C16SX, concentração $50 \mu \mathrm{g} / \mathrm{ml}$ ) em DMEM com 0,5\% de SBF e plaqueadas sobre o mesmo substrato fluorescente serviram como controles. Controles não peptídicos também foram utilizados, e incluíram células mantidas por todo o experimento em DMEM com 0,5\% de SBF (controle negativo não-peptídico) ou em DMEM com 10\% de SBF (controle positivo não-peptídico).

Após período de tratamento com os peptídeos, as amostras foram fixadas em $4 \%$ paraformaldeído, permeabilizadas com $0,5 \%$ Triton X-100 por 5 minutos e bloqueadas com 10\% soro de cabra (Kirkegaard \& Perry Laboratories - KPL, Gaithersburg, MD) por 1 hora. Em seguida, as células foram incubadas com a toxina rodamina-faloidina (Molecular Probes Eugene, Oregon, USA, diluição, 1/5000) por 1 hora para marcação dos filamentos de actina.

Analisamos também a influência dos peptídeos da laminina, AG73 e C16, no comportamento invasivo de uma célula normal. Para tanto, uma linhagem normal derivada de glândula salivar humana (HSG) foi submetida ao ensaio supracitado. Células HSG foram gentilmente cedidas pela Profa. Marinilce Fagundes dos Santos (Departamento de Bilogia celular e do Desenvolvimento, Instituto de Ciências Biomédicas, USP). Sua caracterização já foi descrita anteriormente (SHIRASUNA et al., 1981). Essas células foram cultivadas nas mesmas condições descritas para as células CAC2. O intuito desse experimento foi analisar, de maneira comparativa, a ação dos peptídeos da laminina na atividade invasiva de uma célula tumoral e de uma célula normal.

Também nos interessamos em analisar a distribuição das proteínas cortactina e MT1-MMP nas células CAC2 tratadas pelos peptídeos da laminina. Para tanto, células foram crescidas sobre o substrato fluorescente e tratadas com AG73, C16 e peptídeos controle ("scrambled") "overnight". As amostras foram fixadas, permealibizadas e bloqueadas seguindo mesmo protocolo mencionado anteriormente. Após isso, células foram submetidas à dupla-marcação para as proteínas cortactina e MT1-MMP. A proteína cortactina foi marcada com anticorpo policloclonal gerado em coelho (clone H-191, Santa Cruz Biotechnology Inc., CA, 
USA, diluição 1/1000) por 1 hora em temperatura ambiente. Enquanto que a marcação para a enzima MT1-MMP foi realizada com anticorpo monoclonal gerado em camundongo (clone 5H2, R\&D Systems, Abingdon, UK, diluição 1/200). Os anticorpos primários foram revelados por anticorpos secundários apropriados e conjugados à fluorocromos. A proteína cortactina foi revelada por anti-coelho Alexa 568 e MT1-MMP com anti-camundongo 647, ambos da Invitrogen-Molecular Probes. A montagem das lâminas foi realizada com ProLong Gold antifade reagent (Molecular Probes).

\subsubsection{Microscopia de fluorescência}

Lâminas foram examinadas em microscópio de fluorescência Axiophot, equipado com objetiva de 63x PlanApo 1.4NA (Carl Zeiss Oberkochen, Germany). Aquisição das imagens foi realizada através de câmera CCD digital de alta sensibilidade, específica para amostras fluorescentes (Quantix KAF1400 Metachrome UV, Photometrics Inc, Tucson, AZ, USA). As imagens foram analisadas no software MetaMorph 7.6 (Molecular Devices, Sunnyvale, CA, USA). A proteína actina foi marcada com corante na faixa do vermelho (568 nm) e as áreas de digestão da matriz apareceram como espaços escuros em fundo verde (gelatinFITC). Nos experimentos de dupla-marcação, a proteína cortactina foi marcada com corante na faixa do vermelho (568 nm) e a MT1-MMP com corante na faixa do "far red" (647 nm) e aparece em pseudo-cor azul. O módulo "Multi-dimensional aquisition" do software Metamorph realiza a aquisição em separado de imagens fluorescentes (proteínas em vermelho e/ou pseudo-cor azul) e de imagens da matriz (em verde). Após a aquisição em separado, esse módulo realiza automaticamente a superposição dos diversos canais de fluorescência utilizados. Imagens em múltiplos canais (verde, vermelho e azul) foram também seccionadas opticamente no eixo $Z$. Para tanto utilizamos o acessório motorizado piezo-elétrico controlado pelo software Metamorph. Foram obtidas pelo menos 10 secções ópticas de diferentes amostras, visando realização de projeções ortogonais, reconstruções tri-dimensionais e rederização volumétrica. No entanto, para contornar um problema inerente aos sistemas microscópicos não-confocais que trabalham adquirindo imagens no eixo $Z$, utilizamos o software Volocity. Esse software elimina os planos fora-de-foco através de algoritmos de deconvolução, gerando efeito que se aproxima ao seccionamento óptico proporcionado pela microscopia confocal. 


\subsubsection{Análise de imagem}

Mensuração da área dos focos de digestão da matriz fluorescente mostrou se determinado peptídeo da laminina induziu aumento da atividade de invadopódios, comparado aos controles. Observamos prolongamentos celulares que se projetavam em direção à matriz e coincidiam com áreas de degradação da matriz. Estas regiões foram interpretadas como invadopódios, uma vez que esses são definidos por protrusões celulares ricas em actina que possuem atividade de degradação da matriz peri-celular (CHEN et al., 1985; CHEN, 1989; CONDEELIS e SEGALL, 2003; WEAVER, 2006). No entanto, é importante ressaltar que podemos também verificar pontos de degradação que não co-localizam com os prolongamentos celulares ricos em actina. Essas regiões são consideradas áreas previamente digeridas, já que os invadopódios são estruturas altamente dinâmicas e participam do movimento celular. Essas áreas também foram quantificadas. A análise das áreas degradação foi realizada no software Image J. Para calcular as áreas correspondentes à digestão da matriz, primeiramente, as imagens foram calibradas para análise em $\mu \mathrm{m}^{2}$ de acordo com a objetiva em que foram adquiridas, no caso, a objetiva de 63x (0.107502 $\mu \mathrm{m} /$ pixel). Em seguida, o canal verde (substrato fluorescente) foi processado separadamente através da segmentação da imagem (ferramenta denominada "threshold") com objetivo de ressaltar as áreas mais escuras da imagem, ou seja, as áreas degradadas. As áreas foram medidas e os valores obtidos foram comparados graficamente e analisados estatisticamente. Um total de 10 campos ( 20 células) foi analisado para cada grupo experimental. Os ensaios foram realizados pelo menos duas vezes.

\subsection{6 "Immunoblot"}

A técnica de "immunoblot" foi utilizada para analisar a expressão das proteínas do invadopódio, cortactina e MT1-MMP, nas células CAC2 tratadas pelos peptídeos AG73 e C16. Para tanto, primeiramente, placas foram cobertas pelo substrato de gelatina tipo B (concentração $0,2 \%$ ) contendo ligações cruzadas. A preparação desse substrato foi realizada seguindo o mesmo protocolo descrito no item 4.3.2, no entanto, para "immunoblot" não é necessária a adição de gelatinaFITC. 
Células CAC2 foram então colocadas sobre as placas cobertas com gelatina na presença de DMEM com 0,5\% de SBF. Após 1 hora, os peptídeos AG73 ou C16 $(50 \mu \mathrm{g} / \mathrm{ml})$ foram acrescidos no meio de cultura e as células permaneceram nessas condições "overnight". Células tratadas por peptídeos "scrambled" em DMEM com 0,5\% de SBF e plaqueadas sobre o mesmo substrato serviram como controles. Controles não peptídicos também foram utilizados, e incluíram células mantidas por todo o experimento em DMEM com 0,5\% de SBF (controle negativo não-peptídico) ou em DMEM com 10\% de SBF (controle positivo não-peptídico). As amostras tratadas e controles foram lisadas com tampão RIPA (150 mM de NaCl, 1\% NP-40, 0,5\% deoxicolato de sódio, 0,1\% de SDS, $1 \%$ de Triton X-100, 2 mM de EDTA, 50 $\mathrm{mM}$ de Tris- $\mathrm{HCl} \mathrm{pH} 8,0$ ) contendo inibidores de protease (pepstatina A, PMSF e E64 , Sigma). Em seguida, as amostras foram centrifugadas a $10.000 \mathrm{~g}$ por $10 \mathrm{~min}$ a 4 ${ }^{\circ} \mathrm{C}$, e o sobrenadante foi recolhido. Quantificação de proteínas foi realizada através do método BCA (Pierce Inc., Rockford, IL, USA).

Eletroforese foi realizada seguindo protocolo para SDS-PAGE. O lisado celular foi ressuspendido em tampão de amostra (3\% de SDS, $150 \mathrm{mM}$ de Tris pH $6,8,15 \%$ de $\beta$-mercaptoetanol, $30 \%$ de glicerol e $0,01 \%$ de azul de bromofenol) e carregado em gel de poliacrilamida 10\% (preparado com 1,5 M de Tris-HCL, 10\% SDS, $30 \%$ bis-acrilamida, $10 \%$ de persulfato de amônia e TEMED). As amostras forma carregadas no gel em igual quantidade protéica $(40 \mu \mathrm{g})$. Após a eletroforese, as bandas protéicas foram transferidas para membrana de nitrocelulose (Amersham Co, Arlington Heights, IL, USA) que posteriormente foram bloqueadas com $5 \%$ de leite desnatado em 0,05\% de Tween-20 em TBS (TTBS), e incubadas com anticorpos contra cortactina (clone H-191, Santa Cruz, diluição 1/500) e MT1-MMP (clone H-191, Santa Cruz, diluição 1/500). Esses anticorpos primários foram detectados por anticorpos secundários conjugados a peroxidase (Amersham). Protocolo de quimioluminescência (ECL, kit, Amersham) foi utilizado para revelar a reação em filmes fotográficos. Para possibilitar a marcação com diferentes anticorpos, as membranas foram "stripped" com "Restore Western Blot Stripping Buffer" (Pierce).

Para garantir que a mesma quantidade de proteína de todos os grupos experimentais foi carregada no gel, as membranas foram "stripped" e remarcadas 
para $\beta$-actina (Sigma, diluição 1/2000), representando o controle interno do experimento.

\subsection{Estudo do papel da integrina $\beta 1$ na atividade de invadopódio mediada por AG73 e C16 em células CAC2}

\subsubsection{RNA de interferência para integrina $\beta 1$}

Buscando uma maior compreensão sobre os componentes envolvidos nos processos de sinalização mediados por AG73 e C16, realizamos ensaios com células silenciadas com RNA de interferência (RNAi). Para tanto, obtivemos comercialmente RNAi para integrina- $\beta 1$ (Santa Cruz), meio de tranfecção (Optimen, Invitrogen) e reagente de tranfecção (Lipofectamina 2000, Invitrogen).

Células CAC2 foram cultivadas em placas de 6 poços até atingirem $50 \%$ de confluência. Em seguida, meio de tranfecção, reagente de tranfecção e RNAi para integrina- $\beta 1$ (concentração $50 \mathrm{nM}$ ) foram combinados e incubados a temperatura ambiente por 30 minutos. Essa solução foi adicionada às células CAC2 que foram assim mantidas por 30 horas a $37^{\circ} \mathrm{C}$. Como controle, outro grupo de células foi transfectado com 50 nM de RNAi de sequencia "scrambled" (composição de propriedade da Santa (ruz), que não induz degradação de qualquer mensagem celular. Após o período de incubação, células transfectadas com RNAi para integrina- $\beta 1$ ou RNAi controle foram tripsinizadas e submetidas a 1) técnica de "immunoblot" e 2) Ensaio de degradação de substrato fluorescente e detecção de invadopódios.

\subsection{2 "Immunoblot" para análise da eficiência de inibição de integrina- $\beta 1$}

Técnica de "immunoblot" foi utilizada para verificar se o tratamento com RNAi foi eficaz para inibição da integrina- $\beta 1$. Para tanto, células transfectadas com RNAi para integrina- $\beta 1$ e "scrambled" (controle) foram lisadas com tampão RIPA e carregadas em gel de eletroforese seguindo o protocolo de "immunoblot" já descrito. A membrana foi incubada com anticorpo contra integrina- $\beta 1$ (policlonal gerado em coelho CD29, Chemicon, diluição 1/500). Protocolo de quimioluminescência (ECL, kit, Armeshan) foi utilizado para revelar a reação. 
4.4.3 Ensaio de degradação de substrato fluorescente e detecção de invadopódios em células inibidas para integrina- $\beta 1$

Após tratamento com RNAi, ambas as amostras, tratadas com RNAi para integrina- $\beta 1$ ou RNAi controle, foram plaqueadas sobre a gelatina-FITC. Após 1 hora do plaqueamento, ambas as amostras (RNAi para $\beta 1$ ou RNAi controle) foram tratadas com os peptídeos ou peptídeos "scrambled", mantidas "overnight" sobre o substrato fluorescente e marcadas para actina como já descrito. Como controle positivo, utilizamos também, células transfectadas com RNAi para $\beta 1$ ou RNAi controle e mantidas por todo o experimento com $10 \%$ de SBF sem nenhum tratamento com peptídeo. Para analisar o papel da subunidade $\beta 1$ da integrina na atividade dos invadopódios estimulada pelos peptídeos, realizamos a mensuração das áreas de digestão das amostras tratadas e controles, conforme descrito anteriormente.

\subsection{Estudo das vias de sinalização envolvidas na atividade de invadopódio mediada por AG73 e C16 em células CAC2}

4.5.1 Inibição das vias de sinalização ERK1/2 e Rac1 seguido de ensaio de degradação de substrato fluorescente

Decidimos analisar também o papel das vias ERK1/2 e Rac1 na formação de invadopódios induzida pelos peptídeos da laminina. Para essa análise, utilizamos inibidores específicos para bloqueio dessas vias. Para inibição da via ERK, utilizamos inibidor específico de MEK, U0126 (Cell Signaling Technology, Beverly, MA, USA) na concentração de $50 \mu \mathrm{M}$. Inibição da via Rac1 foi realizada através do

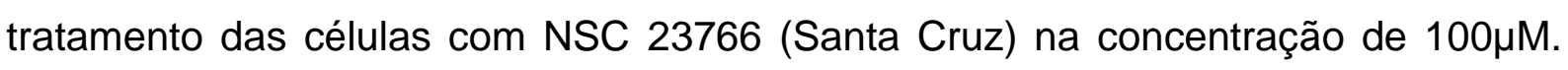
Após tripsinização, células foram pré-tratadas com os inibidores diluídos em DMEM com $0,5 \%$ de soro por 10 minutos a $37^{\circ} \mathrm{C}$. Células tratadas com o veículo apropriado ao inibidor serviram como controles. No caso do U0126, utilizamos como veículo metanol, já para o NSC 23766, utilizamos água ultra-pura (Millipore). Seguido do tratamento com inibidores (U0126 ou NSC 23766) ou veículos (metanol ou água ultra-pura), células CAC2 foram submetidas ao mesmo protocolo, de ensaio de degradação de substrato fluorescente, já descrito anteriormente. É importante frisar que, como no protocolo já citado, os peptídeos (AG73 ou C16) ou peptídeos "scrambled" (AG73SX ou C16SX) foram apenas acrescidos ao meio de cultura e, 
portanto, as células ficaram em contato com os inibidores ao longo de todo o experimento. Para analisar o efeito do bloqueio das vias na atividade dos invadopódios estimulada pelos peptídeos, foi realizada mensuração dos focos de digestão das amostras tratadas e controles, conforme descrito anteriormente.

\subsection{2 "Immunoblot" para análise da eficiência de inibição da via ERK1}

Para analisar se a inibição por U0126 foi específica, realizamos "immunoblot" visando detectar ERK total e fosfo-ERK. Para isso, células pré-tratadas com U0126 ou metanol foramc olocadas sobre placas cobertas com gelatina tipo $\mathrm{B}$ e dada 1 hora após o plaqueamento, foram incubadas com peptídeos ou peptídeos "scrambled". As células permaneceram nessas condições "overnight". Após esse período, as amostras foram lisadas com tampão RIPA contendo inibidores de

proteases e fosfatases. O protocolo de "immunoblot" utilizado foi descrito anteriormente. Os anticorpos contra ERK total e fosfo-ERK foram obtidos da Santra Cruz (ambos policlonais gerados em coelhos). Os anticorpos foram utilizados nas seguintes concentrações: 1/500 para marcações de ERK total e 1/250 para fosfoERK.

\subsection{Análise estatística}

Dados obtidos a partir dos experimentos foram analisados usando o software GraphPad Prism 5 (GraphPad Software, Inc., San Diego, CA, USA. Teste t de "Student" foi utilizado para avaliar diferenças entre dois grupos. Diferenças entre três ou mais grupos foram estimadas através de análise de variância (ANOVA), seguido por teste de comparações múltilplas de Bonferroni. 


\section{RESULTADOS}

\subsection{Marcadores de invadopódio estão expressos no Carcinoma adenóide cístico in vivo}

Estudos já demonstraram que a cortactina e a MT1-MMP têm papel importante na dinâmica e função dos invadopódios (ARTYM et al., 2006; CLARK et al., 2007; CLARK e WEAVER, 2008; OSER et al., 2009). Por tal motivo, resolvemos investigar a expressão dessas proteínas no carcinoma adenóide cístico in vivo.

Dois subtipos histológicos do carcinoma adenóide cístico podem ser verificados na Figura 1, o cribriforme (A, D e E) e o tubular (B). A figura 1C demonstra uma região de invasão perivascular evidenciada pelo asterisco. Nossos resultados mostraram que tanto a proteína cortactina quanto a MT1-MMP foram detectadas in vivo no tumor nos dois subtipos histológicos verificados (Fig. 1). A enzima MT1-MMP foi observada como proeminente marcação linear na região periférica das células (cabeça-de-seta, Fig. 1A). Já a expressão de cortactina foi detectada por todo citoplasma das células tumorais (Fig. 1B, C). O asterisco da Figura 1B indica um sítio característico de invasão perivascular com células marcadas para cortactina. Controles negativos de camundongo e coelho não apresentam marcação (Fig. 1D e E). Em trabalho anterior, verificamos que as células do carcinoma adenóide cístico também expressam cortactina e MT1-MMP (NASCIMENTO et al., 2009). 
FIGURA 1 
Figura 1 - Cortactina e MT1-MMP estão presentes no carcinoma adenóide cístico in vivo. MT1-MMP é observada como uma forte marcação linear ao redor das células neoplásicas (A). Expressão de cortactina é detectada por todo citoplasma dessas células $(B, C)$. Asterisco em $C$ indica um típico sítio de invasão perivascular. Controles negativos de camundongo e coelho não apresentam marcação (D, E). Escala: $50 \mu \mathrm{m}$ 

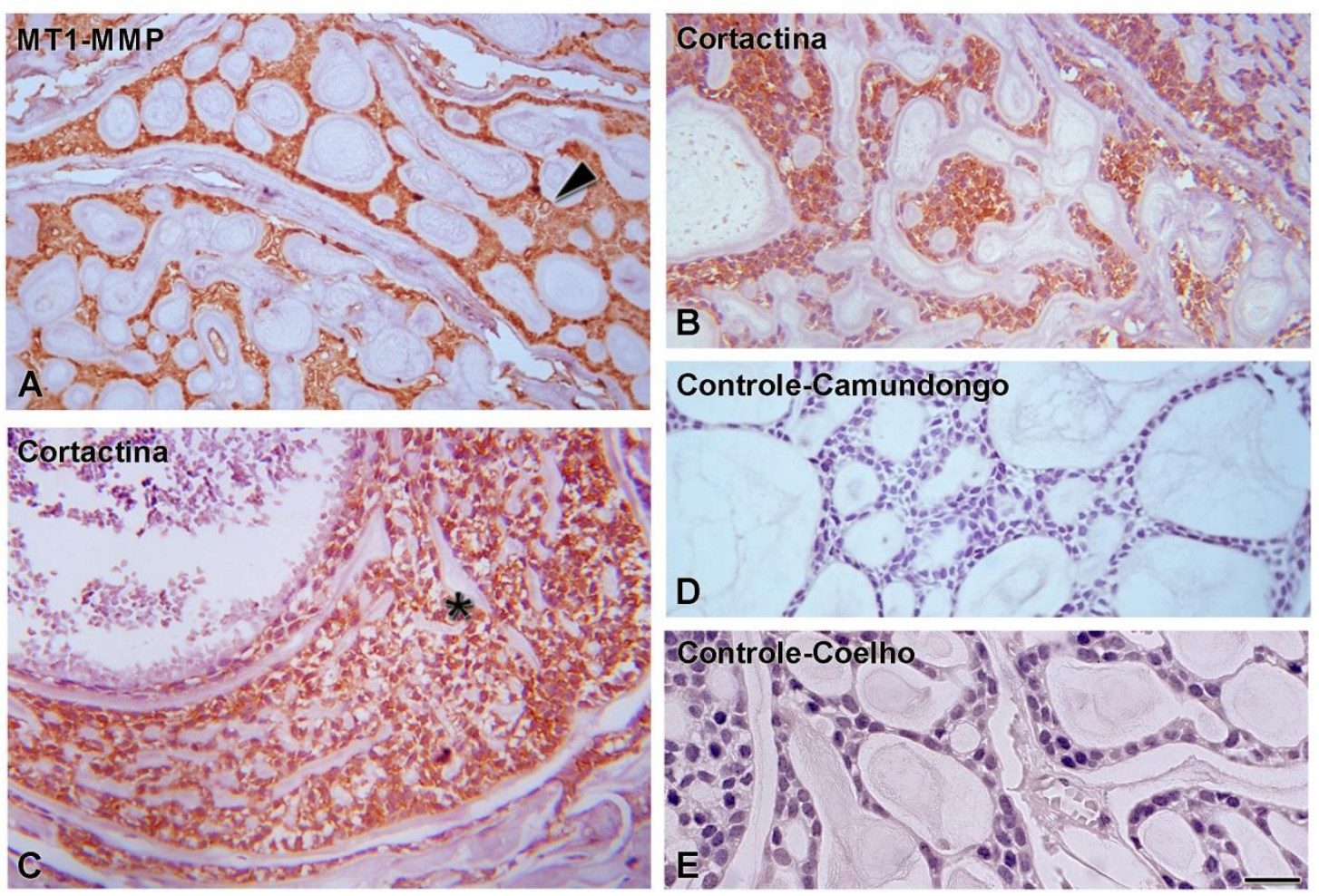

Figura 1 - Cortactina e MT1-MMP estão presentes no carcinoma adenóide cístico in vivo 


\subsection{Peptídeos da laminina-111 aumentam atividade de invadopódio nas células CAC2, mas não nas células HSG}

Ensaio de degradação de substrato fluorescente demonstrou que os peptídeos AG73 (Fig. 2) e C16 (Fig. 3) aumentaram a atividade de invadopódio nas células CAC2 quando comparadas com os peptídeos controle (peptídeos "scrambled"). A atividade de invadopódio é verificada pela presença de extensas áreas escuras (áreas de degradação) no substrato fluorescente verde (Figs. 2A e 3A). A marcação para actina em vermelho demonstra que as protrusões celulares penetram nas áreas degradação (cabeças-de-seta nas projeções ortogonais, Figs. 2A e 3A). Tal atividade de degradação e formação de invadopódios não foi observada nas células tratadas pelos peptídeos "scrambled" (Fig. 2B e 3B). As células CAC2 tratadas pelo peptídeo AG73 tiveram um aumento de seis vezes na atividade de degradação quando comparadas com as células tratadas pelo peptídeo AG73 "scrambled", AG73SX (Fig. 2C). Com relação ao peptídeo C16, foi verificado um aumento de 40 vezes nas áreas de degradação quando comparado com o C16SX (Fig. 3C). Esses ensaios foram realizados pelo menos três vezes e apresentaram resultados semelhantes.

A obtenção de planos no eixo $Z$, seguidos de restauração algorítmica e reconstrução tri-dimensional fornecem informações importantes sobre a interação célula-matriz. A Fig. 4 mostra protrusões ricas em actina atravessando a matriz tridimensional de gelatina.

Também realizamos ensaio de degradação de substrato fluorescente com células derivadas de uma linhagem normal de glândula salivar, células HSG (Fig. 5). A partir desses ensaios foi possível verificar que células HSG tratadas pelos peptídeos são capazes de degradar o substrato. No entanto, o padrão de degradação do substrato observado nessas células (Fig 5), apresenta-se de maneira diferente daquele verificado nas células CAC2 (Figs. 2 e 3). Células HSG tartadas pelos peptídeos demonstraram atividade de degradação como, pequenos pontos escuros na matriz fluorescente (Fig. $5 \mathrm{~A}$ e $\mathrm{B})$. Diferentemente das extensas áreas de degradação observadas nas células CAC2 tratadas por AG73 e C16 (Figs. 2A e 3A). Além disso, verificamos que esses pontos de degradação coincidiram com a marcação para actina em uma estrutura semelhante à podossomos. Isso foi verificado em todos os grupos experimentais (cabeças-de-seta, Figs. 5A e B). Além disso, não foi verificada diferença entre os grupos tratados com os peptídeos, AG73 e C16, e os grupos tratados com os peptídeos "scrambled", AG73SX e C16SX (Figs. 5C e D). 
FIGURA 2 
Figura 2 - AG73 aumenta atividade de invadopódios nas células CAC2. Marcação com rodamina-faloidina evidencia protrusões celulares ricas em actina (A e B, projeções ortogonais painéis - Actina). Células tratadas por AG73 demonstram extensa atividade de degradação como áreas escuras na gelatina-FITC (A, asterisco - Gelatina-FITC). Projeções ortogonais demonstram os invadopódios como protrusões ricas em actina que se projetam em direção à matriz digerida (cabeças-de-seta em A). Tal atividade de degradação não é observada nas células tratadas pelo peptídeo "scrambled" (B). Linhas brancas em A e B, indicam os pontos do eixo $X Y$ em que a imagem foi projetada para gerar os planos ortogonais $\mathrm{XZ}$ e YZ. O gráfico demonstra que as áreas de degradação induzidas pelo peptídeo AG73 são seis vezes maiores do que as observadas nas células tratadas pelo AG73SX (C). Asterisco em C indica que esses dados são significantes (C). Linhas horizontais indicam a média da atividade de degradação observada nos controles não-peptídicos (DMEM com 0.5\% SBF e DMEM com $10 \%$ SBF). Dados representam valores medianos com desvio padrão \pm de 30 células analisadas. Escalas: $10 \mu \mathrm{m}$ 

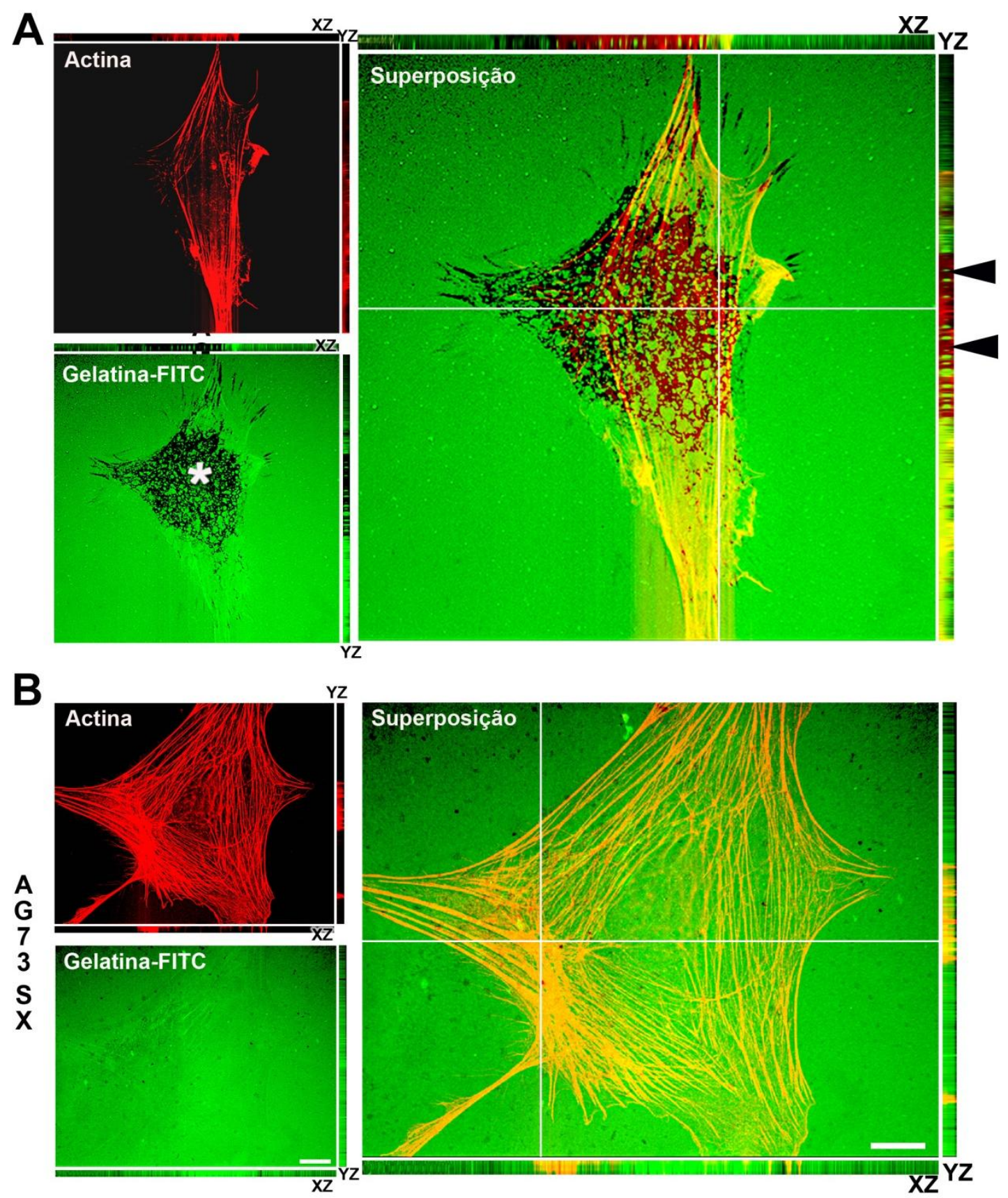

C

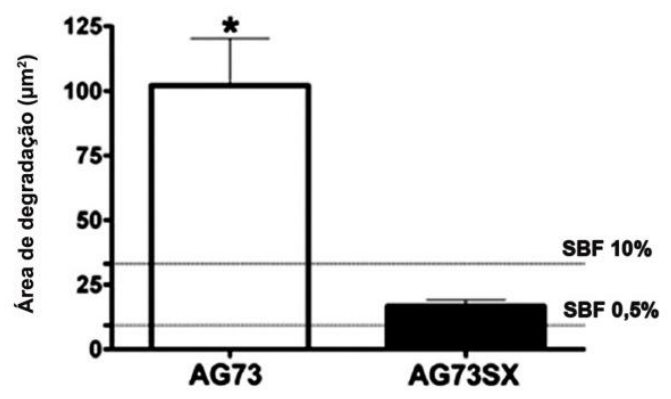

Figura 2 - AG73 aumenta atividade de invadopódios nas células CAC2. 
FIGURA 3 
Figura 3 - C16 regula atividade invadopódios nas células CAC2. Marcação com rodaminafaloidina evidencia os filamentos de actina ( $A$ e $B$, painéis - Actina). Células CAC2 crescidas sobre o substrato fluorescente em contato com AG73 apresentam extensa atividade de invadopódio (asterisco em A). Invadopódios são observados como protrusões ricas em actina projetadas nas áreas de degradação do substrato (cabeças-de-seta em A). Essa atividade de degradação não foi observada nas células tratadas com C16SX (B). Linhas brancas em A e B, indicam os pontos do eixo $X Y$ em que a imagem foi projetada para gerar os planos ortogonais $X Z$ e $Y Z$. O gráfico demonstra que a atividade de invadopódio induzida por C16 é trinta vezes maior do que a verificada nas amostras do peptídeo controle, C16SX (C). Asterisco em C indica significância desses dados. Linhas horizontais indicam a média da atividade de degradação observada nos controles não-peptídicos (DMEM com 0.5\% SBF e DMEM com 10\% SBF). Dados representam valores medianos com desvio padrão \pm de 30 células analisadas. Escalas: $10 \mu \mathrm{m}$ 
A
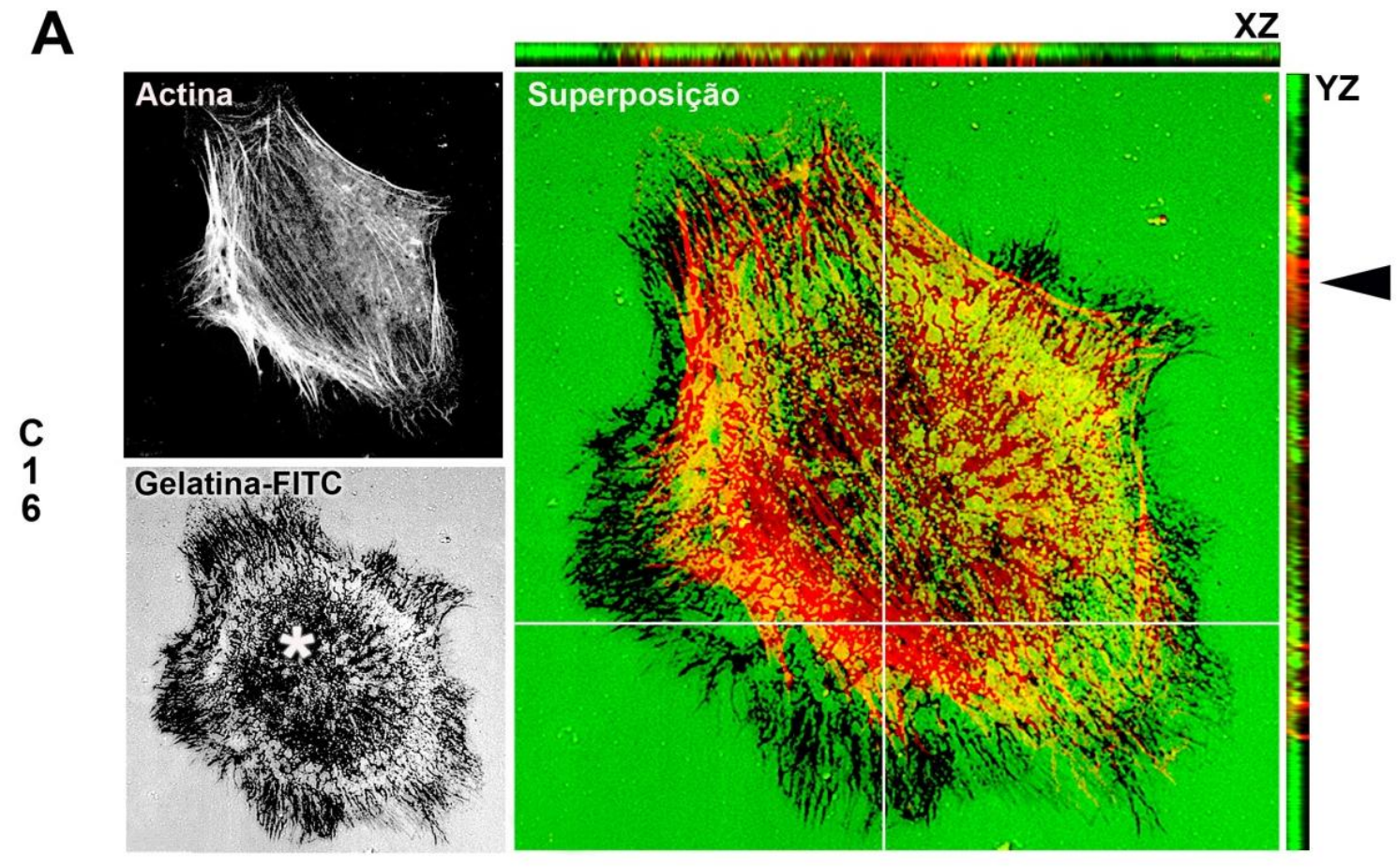

B
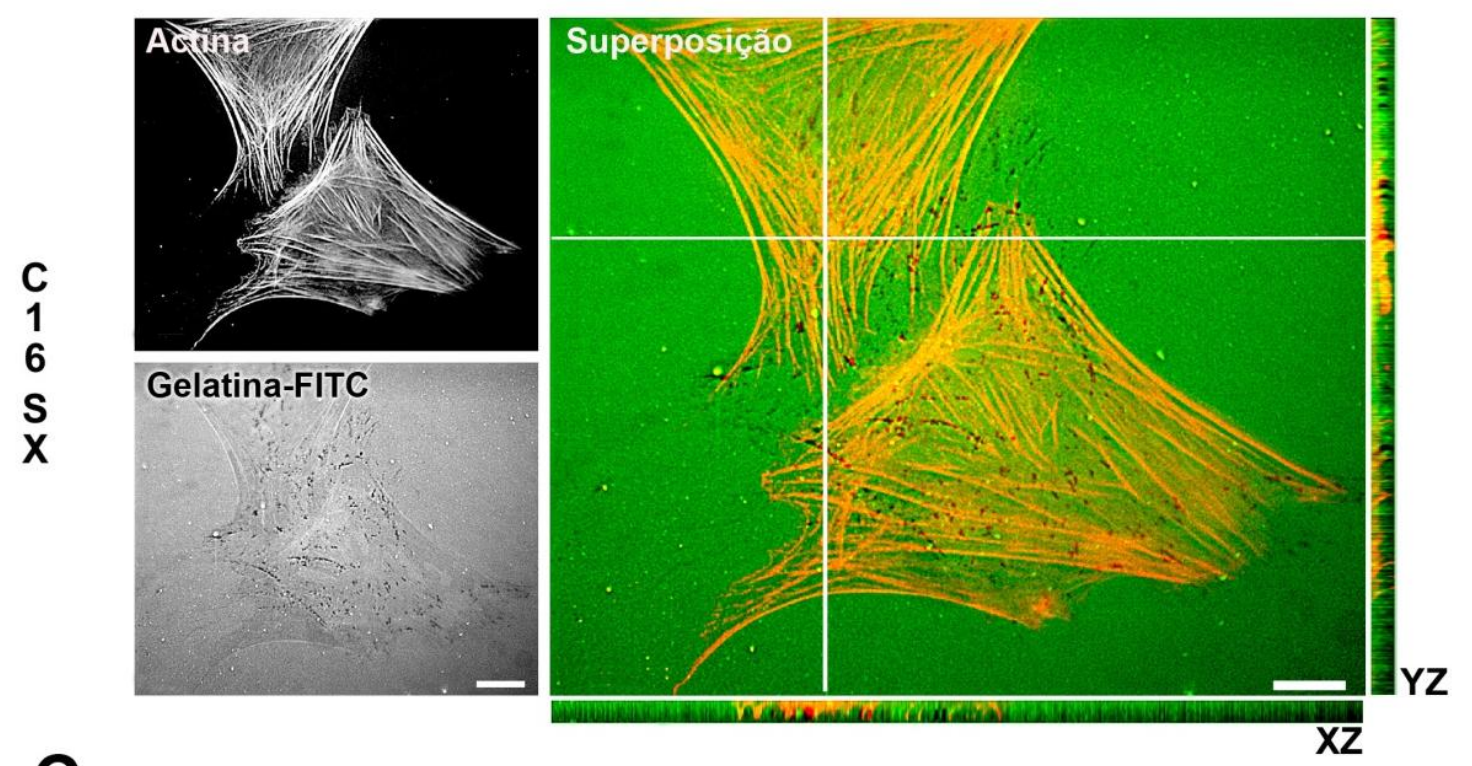

C

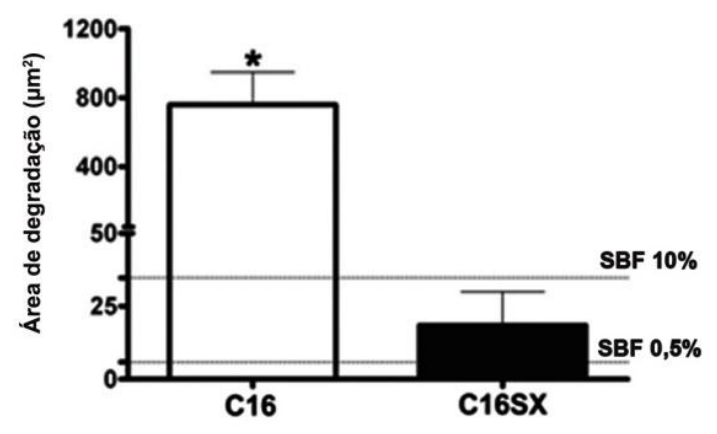

Figura 3 - C16 regula atividade invadopódios nas células CAC2. 
FIGURA 4 
Figura 4 - Restauração algorítmica e reconstrução tri-dimensional evidenciam interação célula-matriz. Células CAC2 tratadas por C16, coradas para actina (vermelho), foram submetidas a restauração algorítmica seguida de renderizacão volumétrica no software "Volocity" (A, B). Observa-se célula sobre a gelatina fluorescente (verde), com prolongamentos mergulhados na matriz (B). Escalas: $10 \mu \mathrm{m}$ 

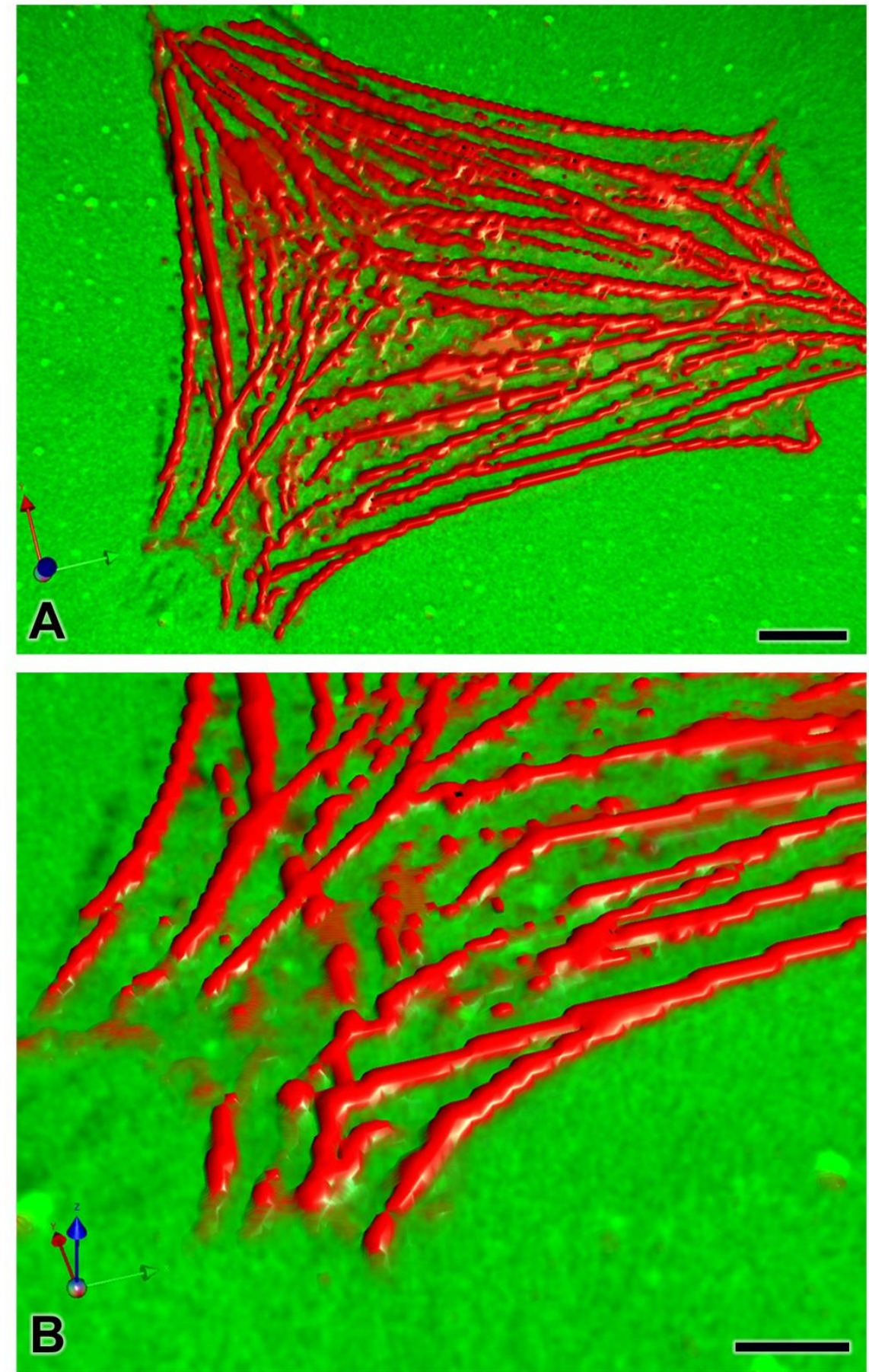

Figura 4 - Restauração algorítmica e reconstrução tri-dimensional evidenciam interação célula-matriz. 
FIGURA 5 
Figura 5 - Peptídeos da laminina não regulam atividade de invadopódio nas células HSG. Células HSG crescidas sobre o substrato fluorescente em contato os peptídeos apresentam atividade de degradação como pontos escuros na gelatina-FITC (A e B). Além disso, verificamos que esses pontos de degradação coincidiram com a marcação para actina em uma estrutura semelhante à podossomos. Isso foi verificado em todos os grupos experimentais ( $\mathrm{A} \mathrm{e} \mathrm{B}$, cabeças-de-seta). Contudo, mensuração das áreas de degradação demonstra que não houve diferença significativa entre as amostras tratadas e controles (C e D). Dados representam valores medianos com desvio padrão \pm de 30 células analisadas. Escala: $10 \mu \mathrm{m}$ 
A
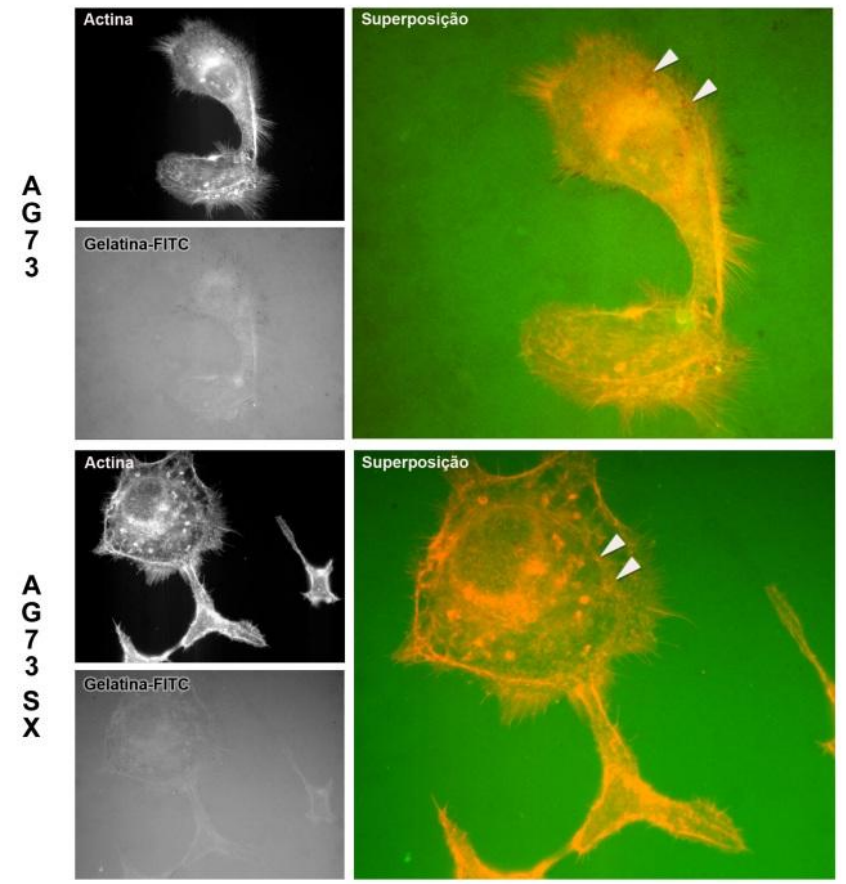

C

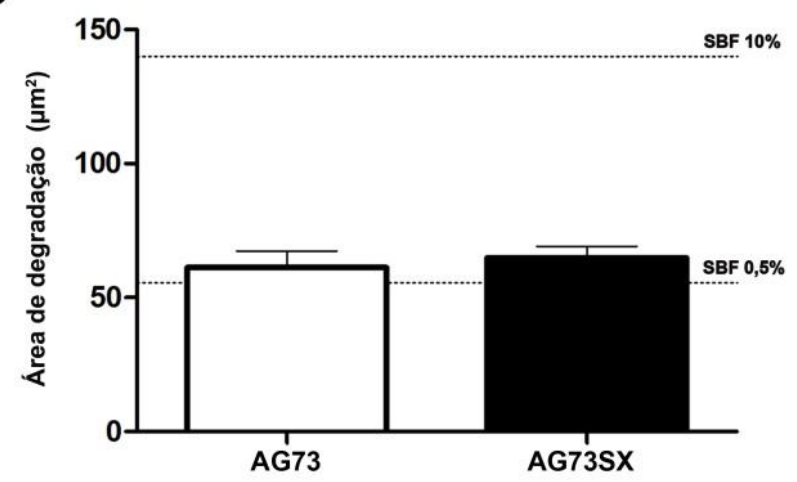

B
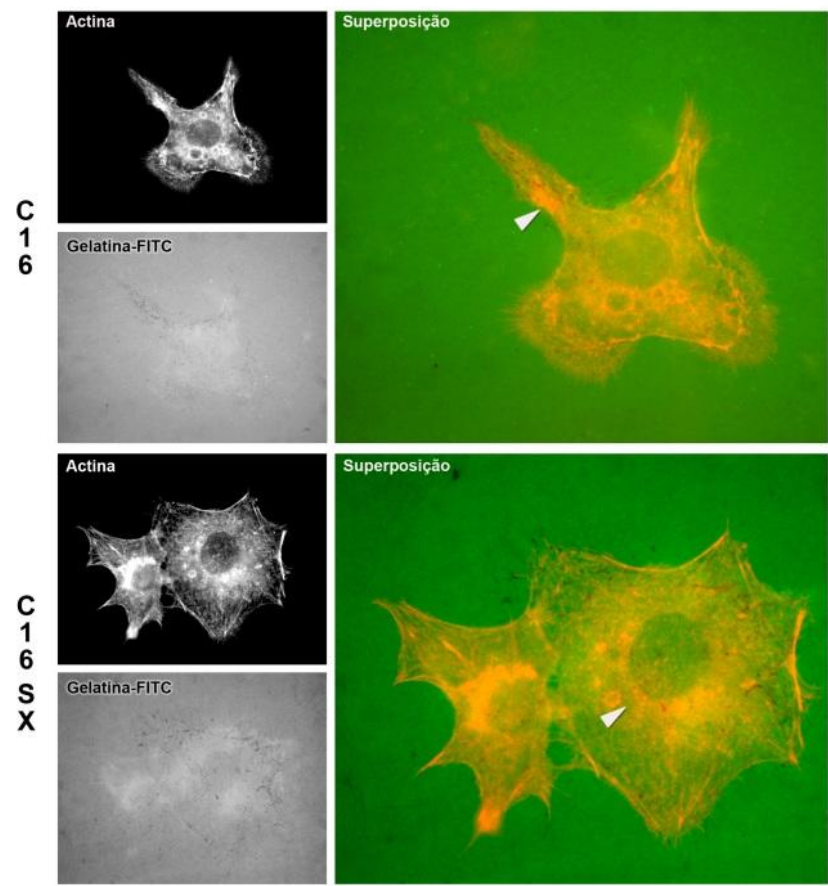

D

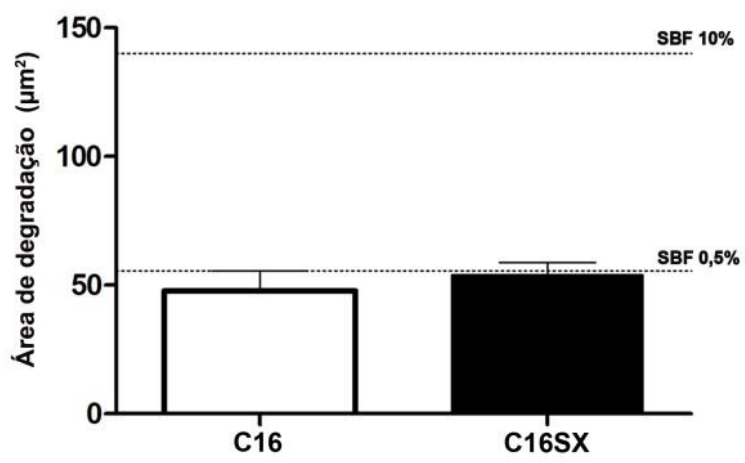

Figura 5 - Peptídeos da laminina não regulam atividade de invadopódio nas células HSG. 


\subsection{Peptídeos da laminina-111 aumentam a expressão de MT1-MMP nas células CAC2}

O estudo das proteínas cortactina e MT1-MMP nos permite analisar de maneira mais crítica o papel dos peptídeos bioativos da laminina na dinâmica molecular dos invadopódios. Já verificamos a expressão dessas duas moléculas nas células CAC2, colocalizadas nas áreas de degradação do substrato fluorescente (NASCIMENTO et al., 2009). No presente estudo analisamos então a expressão de cortactina e MT1MMP em células CAC2 tratadas com os peptídeos da laminina, AG73 e C16 (Figs. 6 e 7). Nessa análise, células tratadas pelos peptídeos e peptídeos "scrambled" foram submetidas ao ensaio de degradação de substrato fluorescente, seguido de duplamarcação para cortactina e MT1-MMP. Marcação puntiforme de ambas as proteínas foi observada em todos os grupos experimentais (Fig. 6A e 7A). A atividade de degradação foi identificada como áreas escuras na gelatina fluorescente (Fig. 6A e 7A). As áreas de degradação nas células tratadas por AG73 ou C16 estavam maiores do que as observadas nas células tratadas pelos peptídeos "scrambled". Colocalização de cortactina e MT1-MMP (áreas em cor rosa) foi observada nas áreas de degradação do substrato, caracterizando os invadopódios em todos os grupos (Fig. 6A e 7A). Projeções ortogonais dos eixos $X Z$ e $Y Z$ demonstram que invadopódios presentes na região ventral das células penetram no substrato degradado (Fig. 6A e 7A). Observamos que a distribuição de cortactina e MT1-MMP foi similar em todos os grupos. No entanto, "immunoblot" mostrou que as células tratadas com AG73 (Fig. 6B) ou C16 (Fig. 7B) tiveram um aumento na expressão de MT1-MMP quando comparado com os controles (Fig. 6C e 7C). Por outro lado, a expressão de cortactina não foi alterada pelo tratamento com os peptídeos (Fig. 6B e 7B). 
FIGURA 6 
Figura 6 - AG73 aumenta a expressão de MT1-MMP nas células CAC2. Ensaio de degradação de substrato fluorescente seguido de dupla-marcação para cortactina e MT1-MMP demonstra distribuição puntiforme dessas proteínas em todos os grupos experimentais (A, painéis - cortactina e MT1-MMP). Superposição dessas duas proteínas também é observada em todos os grupos (A, regiões em cor pink). Contudo, áreas de degradação do substrato estão maiores nas células tratadas com AG73 (A, cabeça-de-seta) do que nas tratadas com AG73SX. No grupo do AG73 projeções ortogonais dos eixos $X Z$ e YZ demonstram que invadopódios se projetam verticalmente em direção a matriz digerida (A). Linhas brancas em A, indicam os pontos do eixo $\mathrm{XY}$ em que a imagem foi projetada para gerar os planos ortogonais XZ e YZ. "Immunoblot" mostra que células tratadas por AG73 apresentaram aumento na expressão de MT1-MMP quando comparada ao grupo controle (B). Expressão de cortactina não é alterada pelo tratamento com AG73 (B). Escala: $10 \mu \mathrm{m}$ 

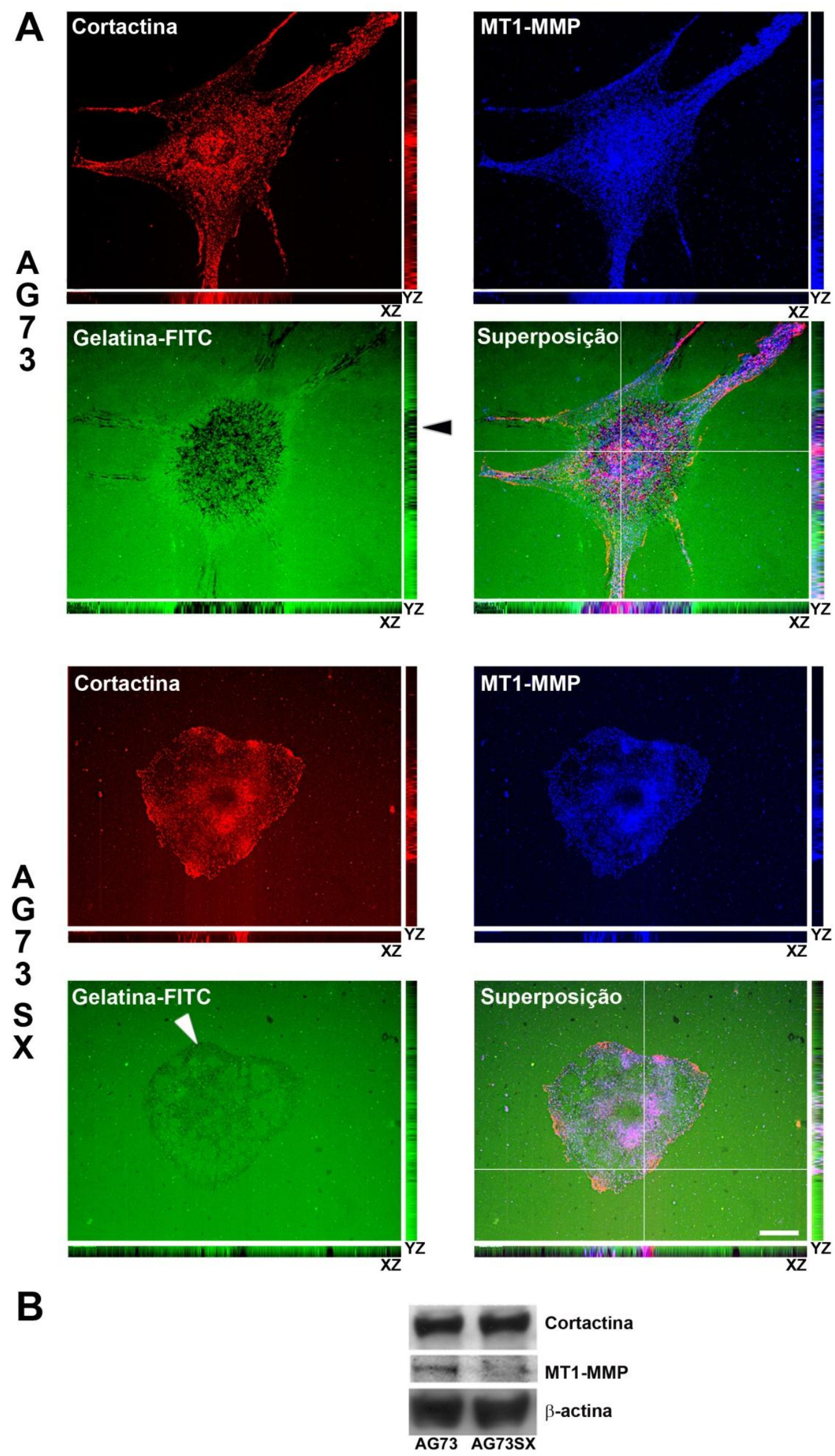

Figura 6 - AG73 aumenta a expressão de MT1-MMP nas células CAC2. 
FIGURA 7 
Figura.7 - C16 aumenta a expressão de MT1-MMP nas células CAC2. Cortactina e MT1MMP apresentam marcação puntiforme de em todos os grupos experimentais $(A$, painéis - cortactina e MT1-MMP). Superposição dessas duas proteínas também é observada em todos os grupos ( $A$, regiões em cor pink). Contudo, áreas de degradação do substrato estão maiores nas células tratadas com $C 16(A$, cabeças-de-seta) do que nas tratadas com C16SX. No grupo do C16, projeções ortogonais dos eixos $X Z$ e $Y Z$ demonstram que invadopódios se projetam verticalmente da região ventral da célula, em direção ao substrato degradado (A). Linhas brancas em $A$, indicam os pontos do eixo $X Y$ em que a imagem foi projetada para gerar os planos ortogonais XZ e YZ. "Immunoblot" demonstra que células tratadas por C16 tiveram aumento na expressão de MT1-MMP quando comparada ao grupo controle (B). A expressão de cortactina não é alterada pelo tratamento com C16 (B). Escala: $10 \mu \mathrm{m}$ 


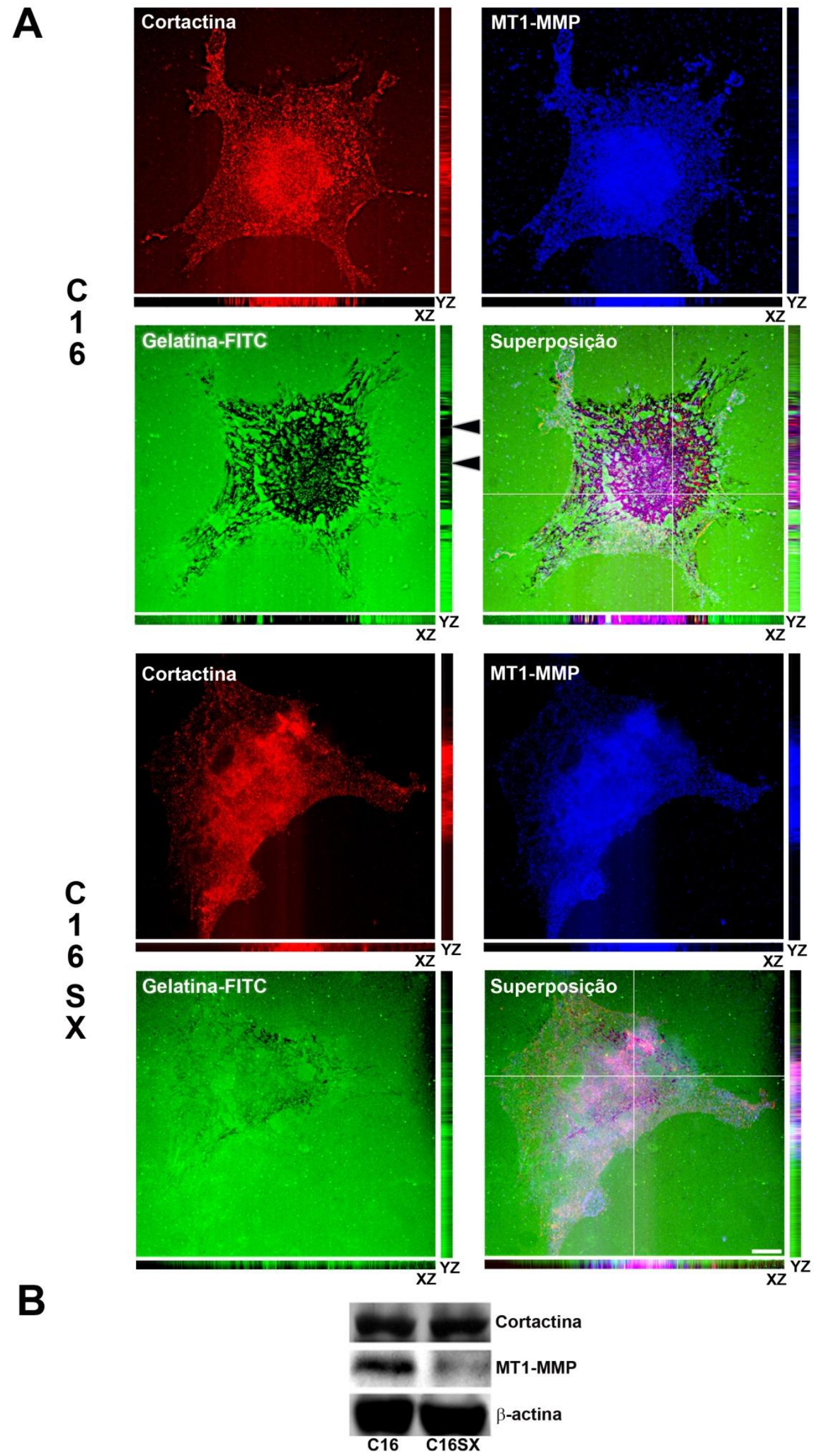

Figura.7 - C16 aumenta a expressão de MT1-MMP nas células CAC2. 


\subsection{Integrina- $\beta 1$ medeia atividade de invadopódio induzida pelos peptídeos da laminina nas células CAC2}

Já demonstramos que peptídeos da laminina-111 cooperam com integrinas (FREITAS et al., 2007; GAMA-DE-SOUZA et al., 2008; SIQUEIRA et al., 2010). Resolvemos então verificar se a subunidade $\beta 1$ da integrina poderia fazer parte da sinalização de AG73 e C16 na formação de invadopódios nas células CAC2. Para essa análise, células CAC2 silenciadas para integrina- $\beta 1$ foram incubadas por AG73 ou C16. Células silenciadas para integrina- $\beta 1$ e posteriormente tratadas com os peptídeos "scrambled" (AG73SX e C16SX) serviram como controle. Como controle do experimento também foram utilizadas células transfectadas com RNAi controle (seqüência "scrambled") e posteriormente tratadas com os peptídeos e peptídeos "scrambled". Como controle positivo, utilizamos também, células transfectadas com RNAi para $\beta 1$ ou RNAi controle e mantidas por todo o experimento com $10 \%$ de SBF sem nenhum tratamento com peptídeo. Amostras tratadas e controles foram submetidas ao ensaio de degradação de substrato fluorescente, seguido de marcação para actina. Inibição de integrina- $\beta 1$ causou uma diminuição na atividade de invadopódio estimulada por AG73 (Fig. 8A) e C16 (Fig. 9A) quando comparada com amostras do grupo RNAi controle. Mensuração das áreas de degradação demonstrou que inibição de integrina- $\beta 1$ promoveu uma diminuição de 4 vezes na atividade de invadopódios induzidos por AG73 (Fig. 8B) e de duas vezes nos induzidos por C16 (Fig. 9B). Nenhuma diferença foi verificada entre os grupos controles (Fig. 8B e 9B). A eficiência da transfecção foi confirmada por "imunnoblot" (Fig. 8C). 
FIGURA 8 
Figura 8 - Subunidade $\beta 1$ da integrina regula invadopódios induzidos por AG73 nas células $C A C 2$. Inibição de integrina- $\beta 1$ diminui atividade de invadopódios induzida por AG73 (A, cabeça-de-seta no painel - siRNA $\beta 1$ ) quando comparado com as células transfectadas com siRNA controle $(A$, cabeça-de-seta no painel - siRNA controle). Mensuração das áreas de degradação demonstra que o silenciamento da integrina- $\beta 1$ promove diminuição de quatro vezes na atividade de invadopódio induzida por AG73 (B). Asterisco em B indica significância entre amostra tratada e controles $(p<0.05)$. Não foi observada diferença significante entre os grupos controle (B). Dados representam valores medianos com desvio padrão \pm de 30 células analisadas. Eficiência da transfecção foi conformada por "immunoblot" (C). Escala: $10 \mu \mathrm{m}$ 
A

\section{AG73}

SiRNA controle
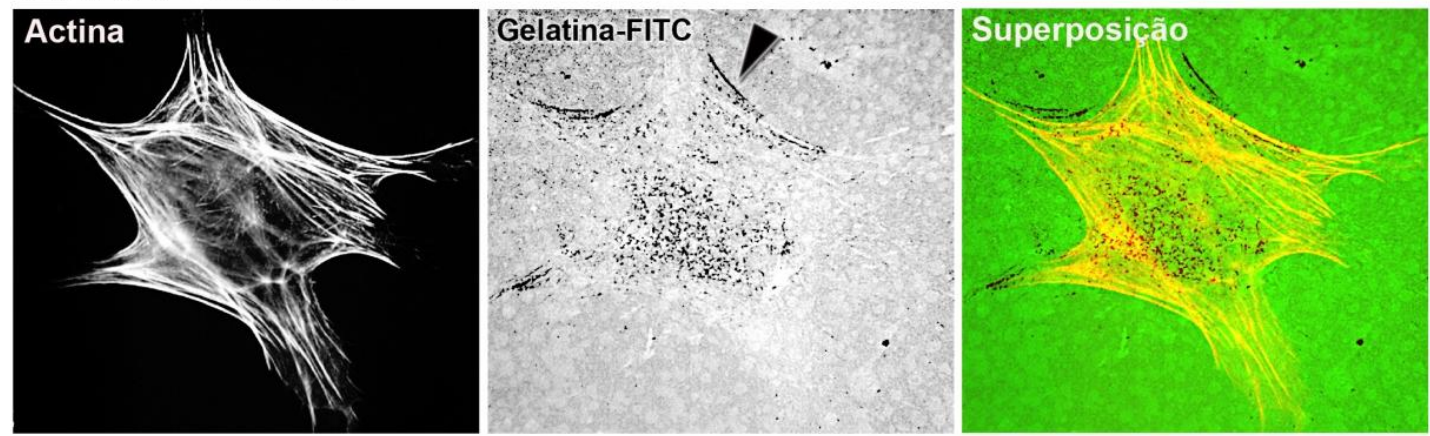

siRNA integrina- $\beta 1$
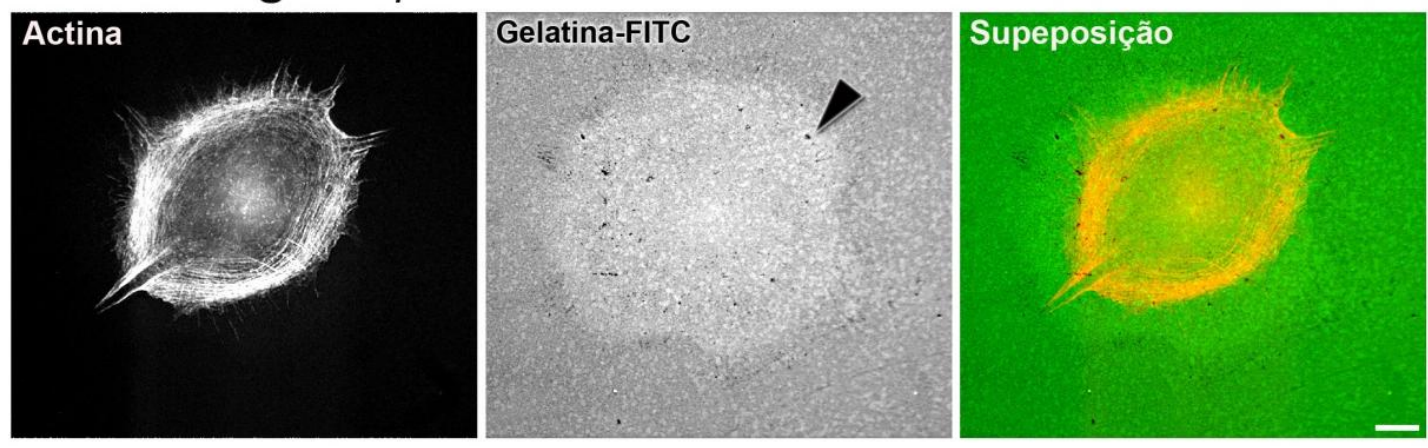

B

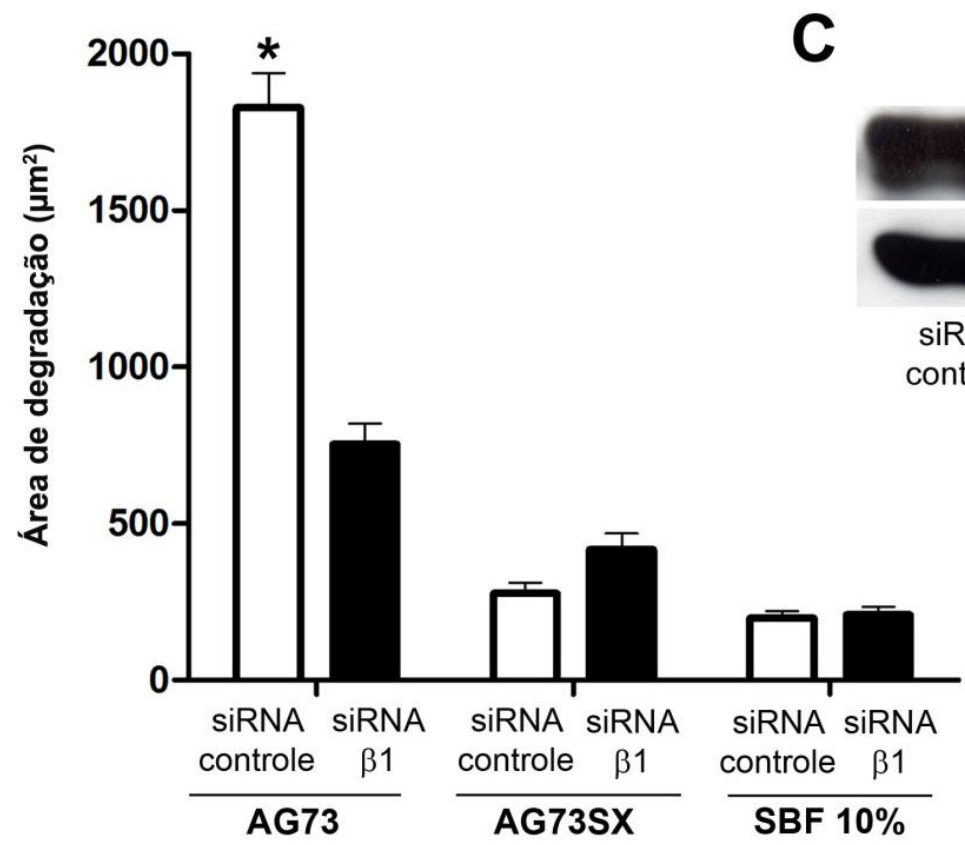

Figura 8 - Subunidade $\beta 1$ da integrina regula invadopódios induzidos por AG73 nas células CAC2. 
FIGURA 9 
Figura 9 - Subunidade $\beta 1$ da integrina modula invadopódios induzidos por C16 nas células CAC2. Silenciamento de integrina $\beta 1$ causa diminuição na atividade de invadopódios induzida por C16 (A, cabeça-de-seta no painel - siRNA $\beta 1$ ) quando comparada com amostras transfectadas com siRNA controle (A, cabeça-de-seta no painel - siRNA controle). Mensuração dos focos de digestão demonstra que a inibição da integrina $\beta 1$ promove diminuição de duas vezes na atividade de invadopódio estimulada por C16 (B). Asterisco em B indica significância entre a amostras siRNA para $\beta 1$ tratadas com $\mathrm{C} 16$ e os controles $(p<0.05)$. Não foi observada diferença significante entre os grupos controles (B). Dados representam valores medianos com desvio padrão \pm de 30 células analisadas. Escala: $10 \mu \mathrm{m}$ 
A

C16

siRNA controle
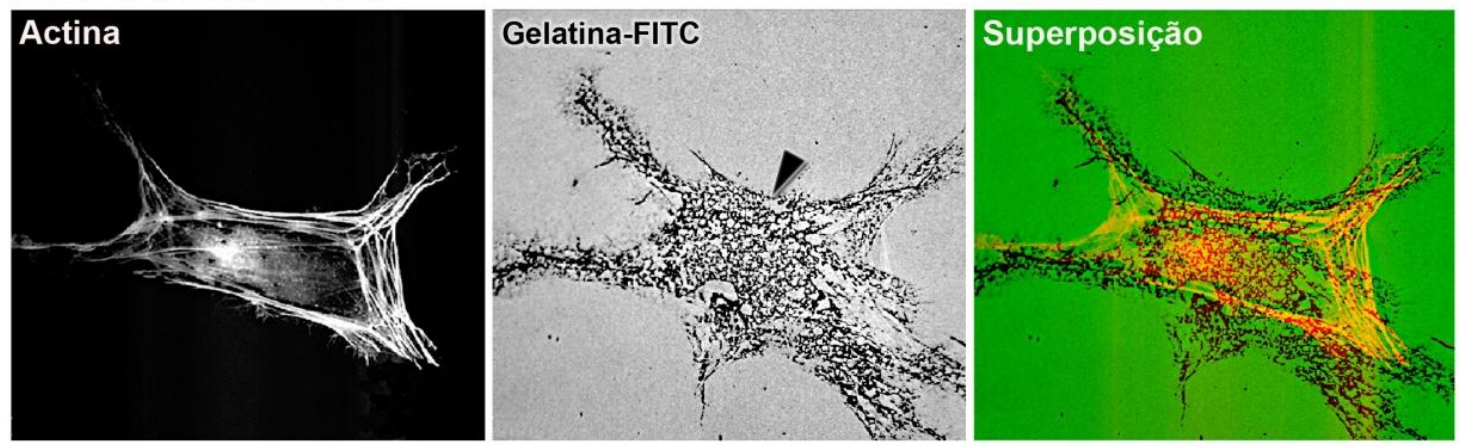

siRNA integrina- $\beta 1$
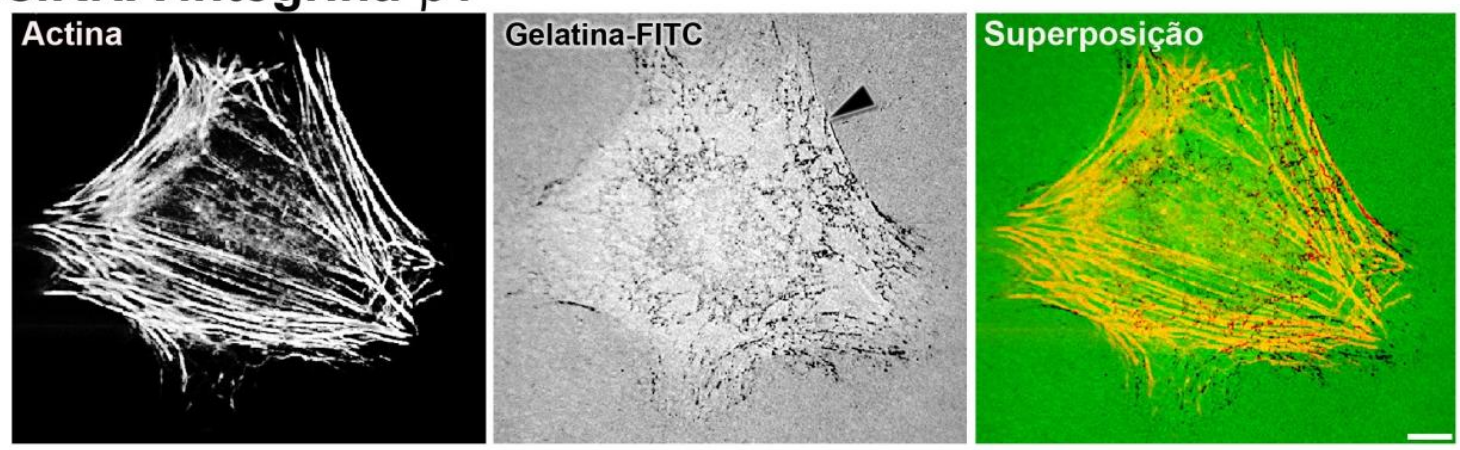

B

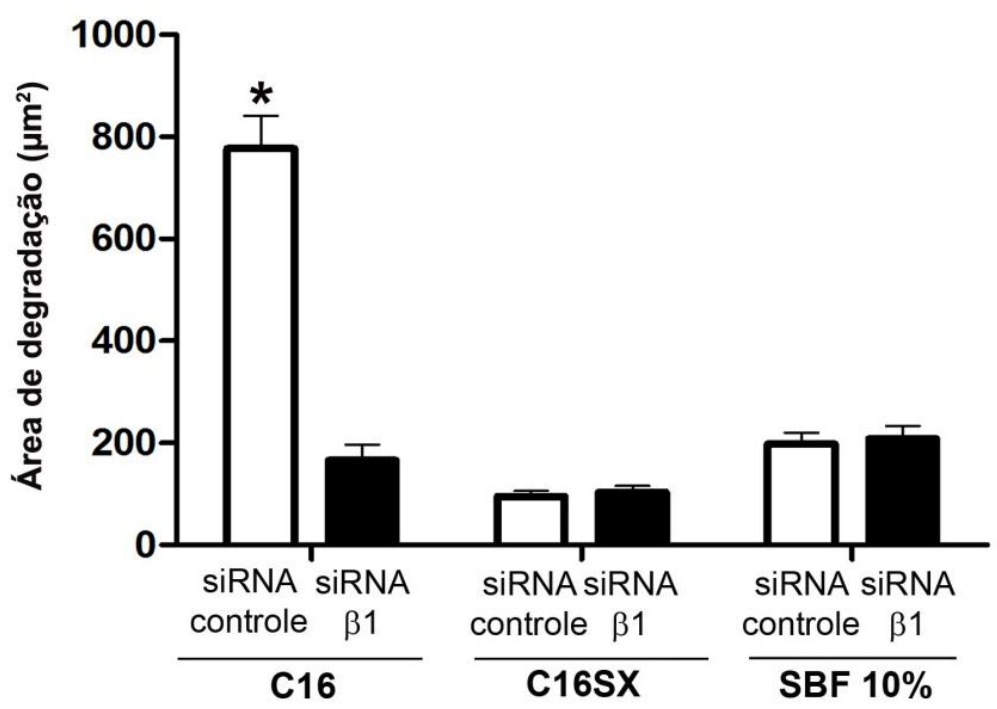

Figura 9 - Subunidade $\beta 1$ da integrina modula invadopódios induzidos por $C 16$ nas células CAC2. 


\subsection{Via de sinalização ERK participa da atividade de invadopódio induzida pelos peptídeos da laminina-111}

Já demonstramos que essa via regula secreção de MMPs nas células CAC2 (FREITAS et al., 2007). Esses dados nos estimularam a analisar o papel da via ERK na atividade de invadopódio induzida pelos peptídeos da laminina nessas células. Para isso, utilizamos um inibidor específico para MEK, o U0126. Observamos uma modificação morfológica em todos os grupos que receberam tratamento com inibidor de ERK. Células pertencentes a esse grupo apresentavam-se arredondadas controle (Fig.10A, U0126 e 11A, U0126) em comparação com as células dos grupos controle (Fig.10A, veículo e 11A, veículo). Além disso, foi observada uma diminuição na atividade de invadopódio nas células CAC2 pré-tratadas com U0126 e posteriormente incubadas com AG73 (Fig.10A) ou C16 (Fig.11A), em relação às células pré-tratadas pelo veículo, e posteriormente incubadas por esses peptídeos. Mensuração das áreas de degradação demonstrou que essa diminuição foi de três vezes (Fig. 10B e 11B). Não foram verificadas diferenças entre as amostras incubadas com os peptídeos "scrambled" (Fig. 10B e 11B). "Immunoblot" para fosfoERK demonstrou que o efeito induzido por U0126 nas células CAC2 foi específico (Fig.10C e 11C). 
FIGURA 10 
Figura 10 - A via ERK participa dos sinais gerados pelo peptídeo AG73 nas células CAC2. Diminuição da atividade de invadopódios induzidos por AG73 é observada em células CAC2 pré-tratadas com U0126 (A, asterisco) quando comparada com as células tratadas com o veículo ( $A$, cabeça-de-seta). Além disso, células tratadas por U0126 apresentaram-se com formato arredondado (A, Actina - painel AG73+U0126). Mensuração das áreas de degradação demonstra que U0126 promoveu uma diminuição de três vezes na atividade de degradação estimulada por AG73 (B). Asterisco em B mostra que esses dados são significantes $(p<0.05)$. Não foram observadas diferenças entre amostras incubadas com peptídeo "scrambled" (B). Dados representam valores medianos com desvio padrão \pm de 30 células analisadas. "Immunoblot" para fosfo-ERK demonstrou que U0126 inibiu a via ERK nas células CAC2 tratadas com o peptídeo (C). Escala: $10 \mu \mathrm{m}$ 
A

AG73+veículo
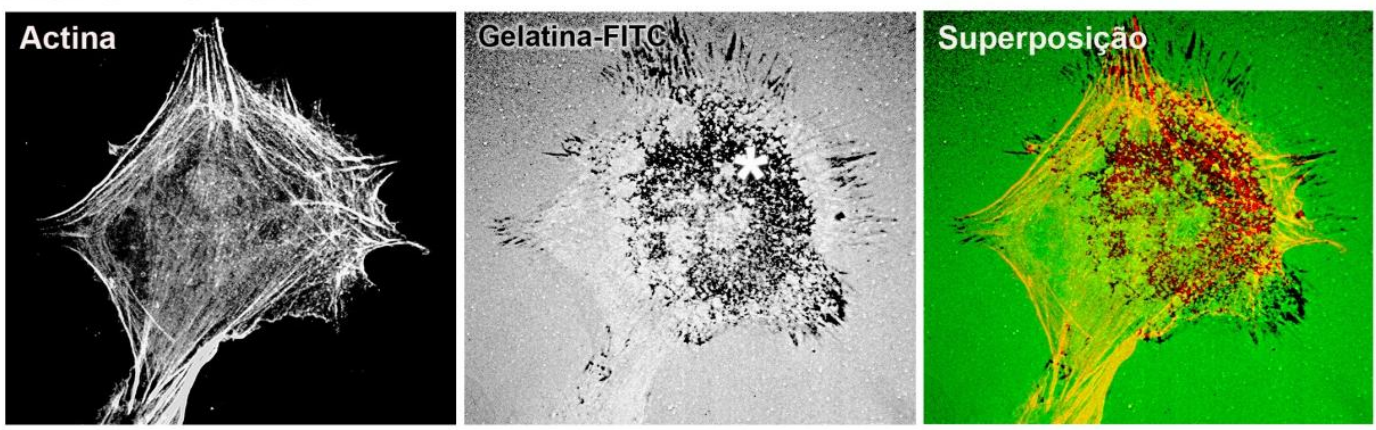

AG73+U0126
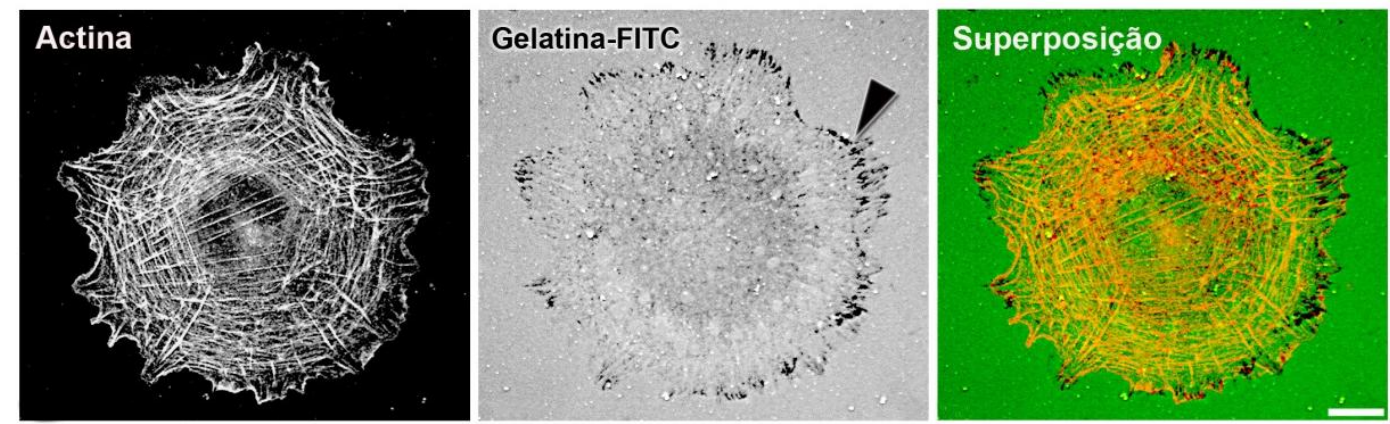

B

Figura 10 - A via ERK participa dos sinais gerados pelo peptídeo AG73 nas células CAC2. 
FIGURA 11 
Figura 11 - A via ERK participa dos sinais gerados pelo peptídeo C16 nas células CAC2. Observa-se diminuição na atividade de degradação induzida por $\mathrm{C} 16$ nas células pré-tratadas com U0126 (A, asterisco) quando comparada com as células tratadas com o veículo (A, cabeça-de-seta). Além disso, células tratadas por U0126 apresentaram-se com formato arredondado (A, Actina - painel C16+U0126). Mensuração dos focos de digestão enzimática demonstra que U0126 promoveu uma diminuição de três vezes na atividade de degradação estimulada por C16 comparada ao controle (B). Asterisco em B mostra que esses dados são significantes $(p<0.05)$. Não foram observadas diferenças entre amostras incubadas com peptídeo "scrambled" (B). Dados representam valores medianos com desvio padrão \pm de 30 células analisadas. "Immunoblot" para fosfo-ERK demonstrou que U0126 inibiu a via ERK nas células CAC2 tratadas com o peptídeo (C). Escala: $10 \mu \mathrm{m}$ 
A

C16+veículo
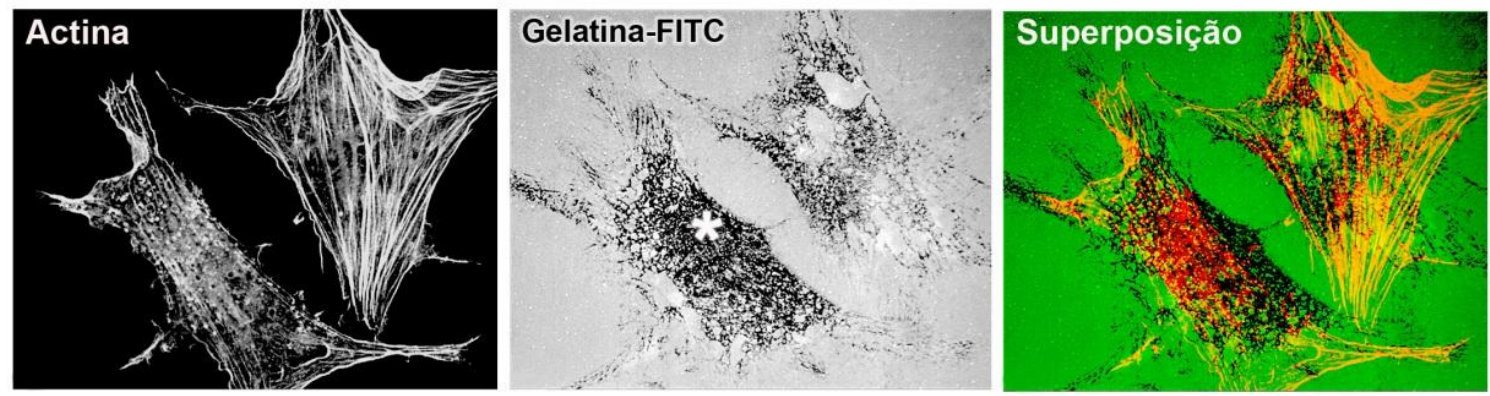

\section{C16+U0126}
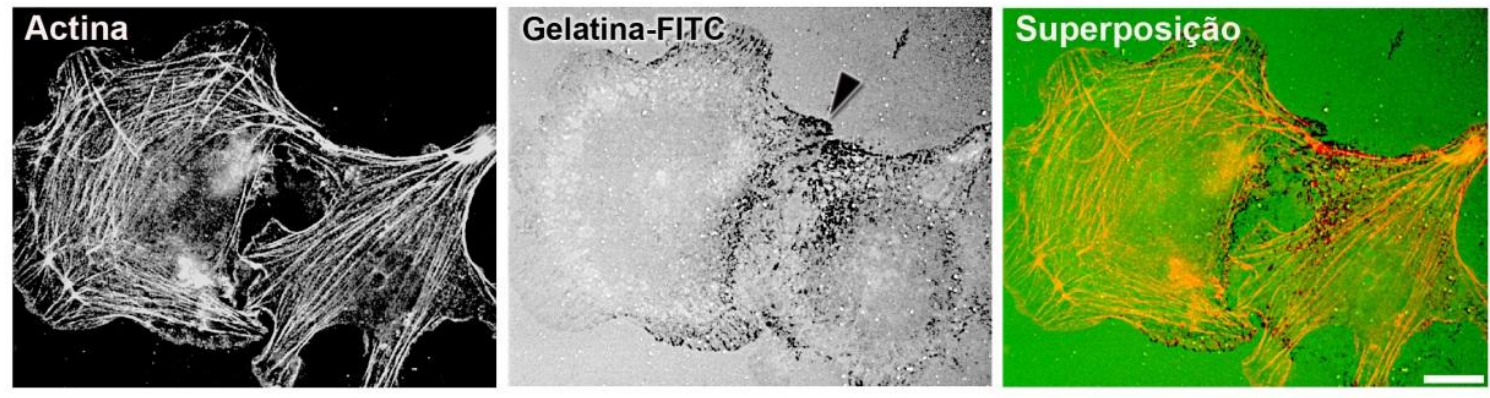

B

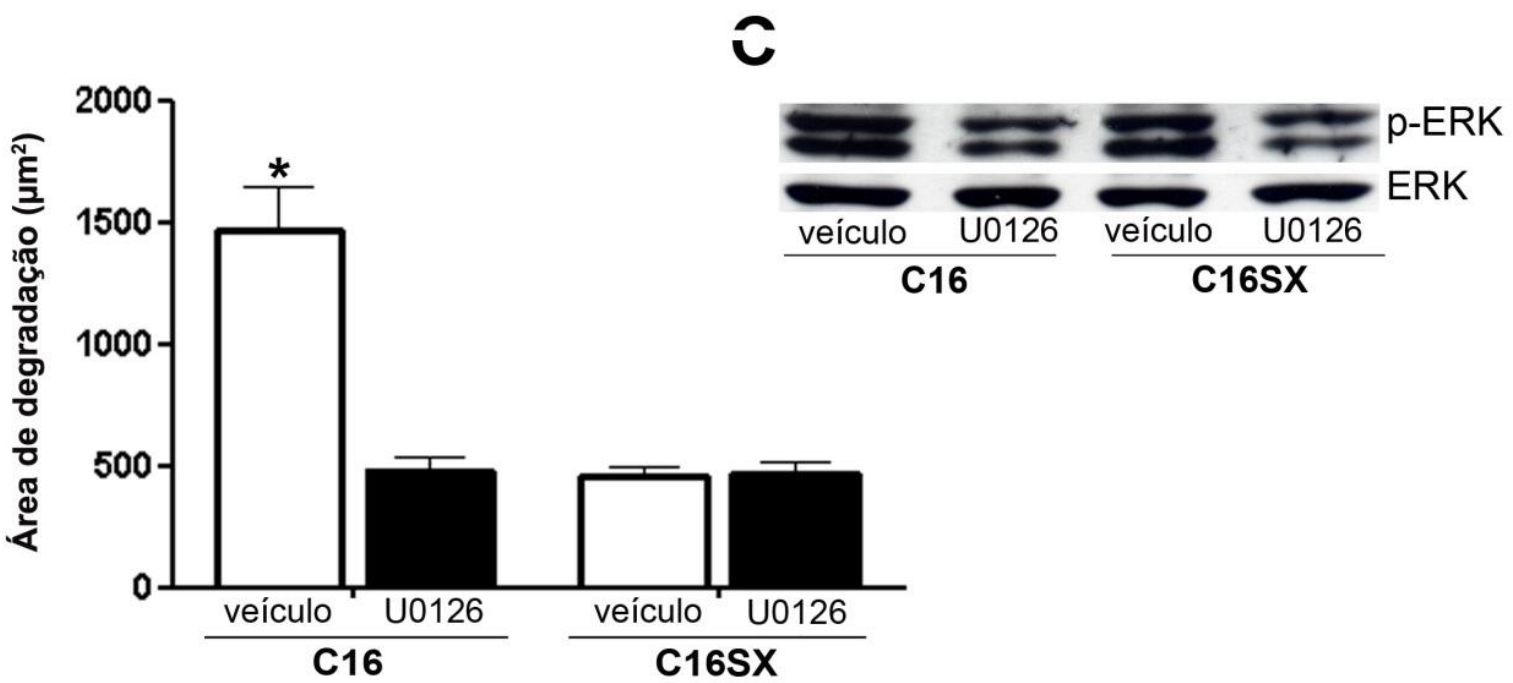

Figura 11 - A via ERK participa dos sinais gerados pelo peptídeo C16 nas células CAC2. 


\subsection{Via de sinalização Rac1 participa da atividade de invadopódio induzida pelo peptídeo AG73}

Rac é membro da família das Rho GTPases, que são importante reguladores da organização do citoesqueleto (ETIENNE-MANNEVILLE e HALL, 2002; JAFFE e HALL, 2005). O papel das GTPases Rho na regulação dos invadopódios já foi verificado (NAKAHARA et al., 2003; YAMAGUCHI et al., 2005; PICHOT et al., 2010; $\mathrm{HU}$ et al., 2011). Analisamos também o envolvimento da via de sinalização Rac1 nos invadopódios induzidos por AG73 e C16. Observamos uma diminuição significante na atividade de invadopódios induzida por AG73 nas células CAC2 tratadas com o inibidor da via Rac1, quando comparado com células incubadas com veículo que foram também tratadas por AG73 (Fig. 12A, B). Por outro lado, o tratamento com o inibidor de Rac1, NSC 23766, não diminuiu a atividade dos invadopódios induzida por C16 (Fig. 13A, B). Amostras tratadas pelos peptídeos "scrambled" não demonstraram diferença na atividade de degradação (Fig. 12B e 13B). 
FIGURA 12 
Figura 12 - A via Rac1 participa dos sinais gerados pelo peptídeo AG73 nas células CAC2. Células tratadas pelo inibidor de Rac1 demonstram diminuição na atividade de invadopódios estimulada por AG73 (A, cabeça-de-seta) quando comparada com células tratadas pelo veículo ( $A$, asterisco). Mensuração dos focos de digestão mostra que o inibidor de Rac1 promoveu uma diminuição de três vezes na atividade de invadopódio induzida por AG73 (B). Asterisco em B mostra que esses dados são significantes. Amostras tratadas pelo peptídeo "scrambled" não mostraram diferença na atividade de degradação (B). Dados representam valores medianos com desvio padrão \pm de 30 células analisadas. Escala: $10 \mu \mathrm{m}$ 
A

\section{AG73+veículo}
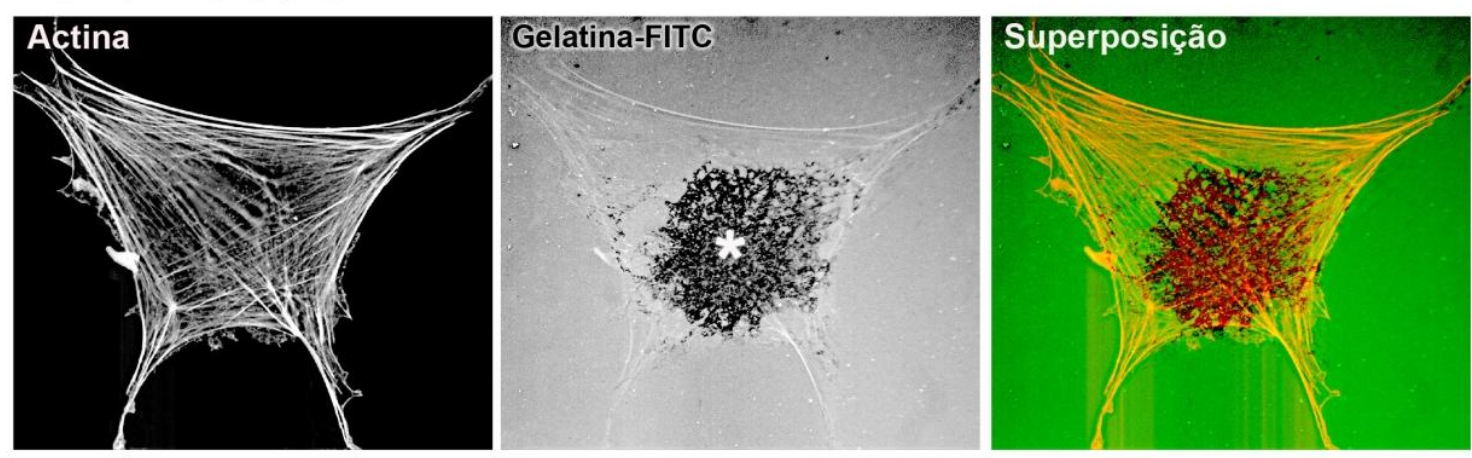

\section{AG73+NSC23766}

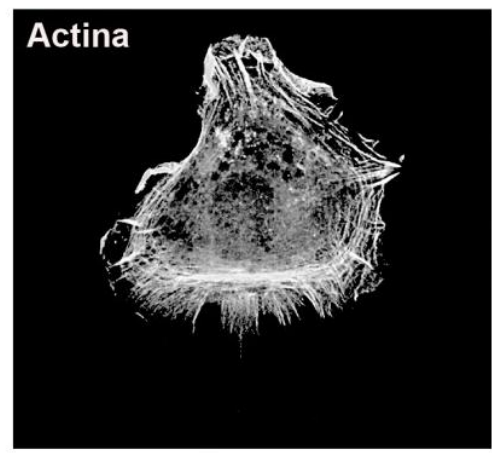

\section{Gelatina-FITC}

B

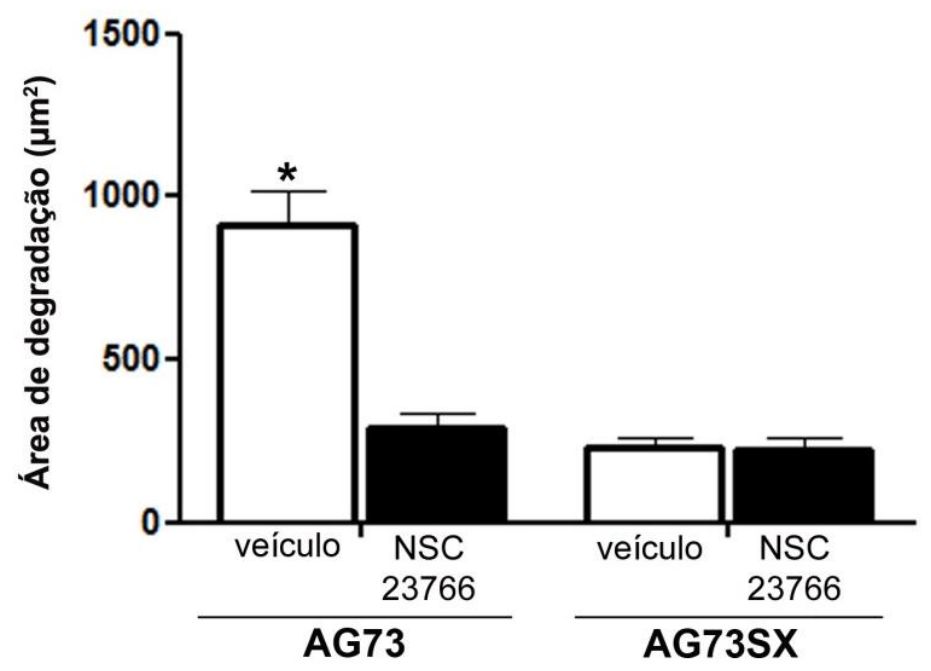

Figura 12 - A via Rac1 participa dos sinais gerados pelo peptídeo AG73 nas células CAC2. 
FIGURA 13 
Figura 13 - A via Rac1 parece não estar envolvida nos sinais gerados pelo peptídeo C16 nas células CAC2. Inibição da via Rac1 não alterou o padrão de atividade de invadopódio induzida por C16 (A, cabeça-de-seta) quando comparado com as amostras tratadas pelo veículo ( $A$, asterisco). Mensuração das áreas de degradação demonstra que não houve diferença significativa entre as amostras tratadas e controles (B). Dados representam valores medianos com desvio padrão \pm de 30 células analisadas. Escala: $10 \mu \mathrm{m}$ 
A

\section{C16+veículo}
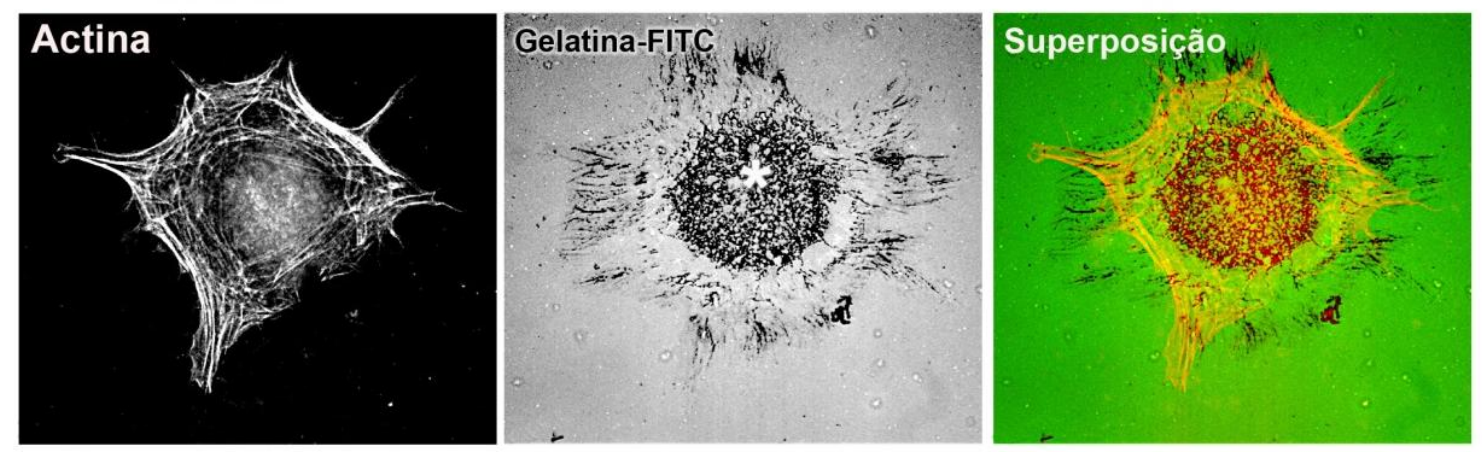

\section{C16+NSC23766}
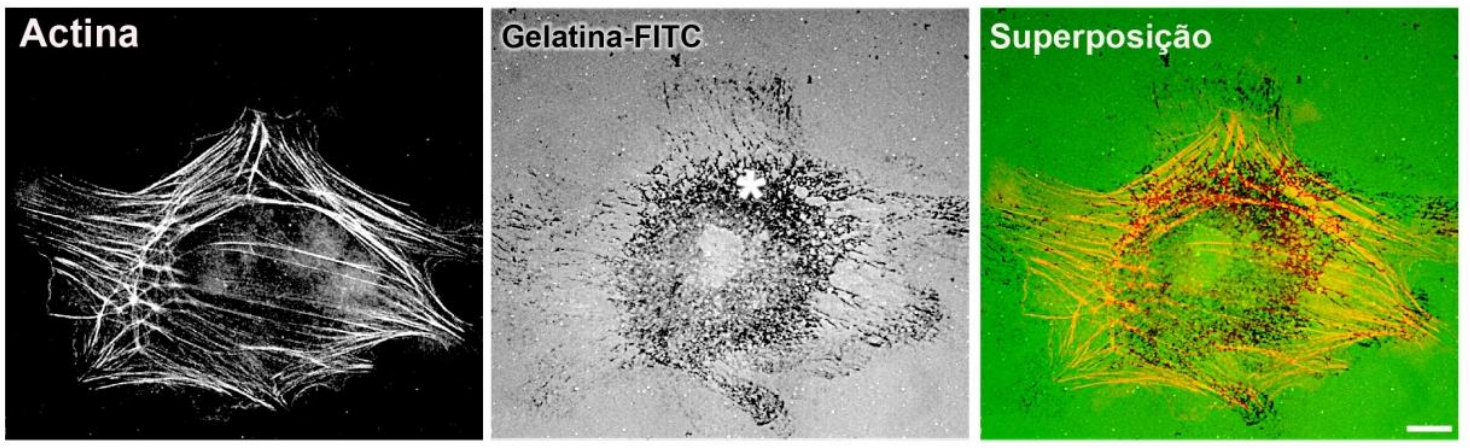

B

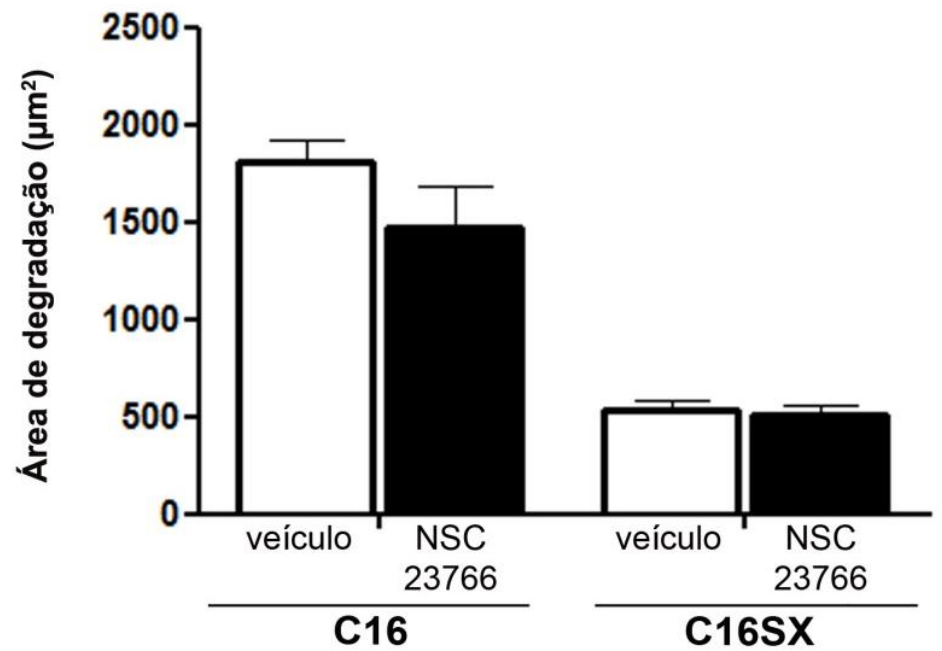

Figura 13 - A via Rac1 parece não estar envolvida nos sinais gerados pelo peptídeo C16 nas células CAC2. 


\section{DISCUSSÃO}

Verificamos marcação das proteínas do invadopódio cortactina e MT1-MMP in vivo no carcinoma adenóide cístico, um tumor maligno de glândula salivar. Demonstramos que os peptídeos da laminina-111, AG73 e C16 regulam atividade de invadopódio na linhagem celular derivada de carcinoma adenóide cístico humano (células CAC2). Além disso, esses peptídeos aumentam a expressão de MT1-MMP nas células CAC2. Investigamos também mecanismos regulatórios envolvidos na atividade de invadopódio estimulada pelos peptídeos nessas células. Experimentos com RNA de interferência para integrina $\beta 1$ demonstraram que esse receptor participa da sinalização dos peptídeos da lamina, provavelmente regulando atividade dos invadopódios. Analisamos também as vias de sinalização que poderiam estar envolvidas nos sinais gerados por AG73 e C16. Inibidor de MAPK diminuiu a atividade de invadopódios nas células CAC2. Isso indica que os sinais gerados por ambos os peptídeos podem ser transduzidos pela via de sinalização ERK1/2. Resultados relacionados com a via Rac1, por sua vez, demonstraram que a mesma parece estar envolvida apenas nos sinais gerados pelo peptídeo AG73. Analisando a literatura, esse é o primeiro relato em que se estabeleceu uma relação entre os peptídeos da laminina-111, AG73 e C16 e a atividade de invadopódios.

O carcinoma adenóide cístico é uma neoplasia maligna de glândula salivar que possui como característica a afinidade por membrana basal de vasos e nervos, e esse aspecto é importante para a metástase desse tumor. No processo de metástase, a proteólise da MEC é uma etapa importante para que ocorra a invasão de células tumorais (BASBAUM e WERB, 1996). Estágios iniciais da invasão celular envolvem a formação de protrusões especializadas da membrana celular, que se projetam em direção à matriz e possuem atividade proteolítica. Essas estruturas, denominadas de invadopódios, provavelmente medeiam a degradação da MEC e o processo de invasão celular (CHEN, 1996; COOPMAN et al., 1998).

Características estruturais e funções dos invadopódios têm sido muito bem elucidadas in vitro (BUCCIONE et al., 2004; MCNIVEN et al., 2004; ARTYM et al., 2006; LINDER, 2007; ALEXANDER et al., 2008; DESAl et al., 2008). Em nível molecular, invadopódios são protrusões filamentosas formadas na região ventral da membrana celular que se projetam em direção á matriz circunjacente (CHEN, 1996; COOPMAN et al., 1998). In vivo, estruturas semelhantes a invadopódios têm sido 
verificadas através de microscopia multi-fóton (YAMAGUCHI et al., 2006) contudo, esse dado ainda não está muito bem caracterizado. Diversas proteínas estão associadas aos invadopódios. No entanto, para compreender os mecanismos envolvidos na dinâmica dos invadopódios, estudos têm focado principalmente em duas proteínas, cortactina e MT1-MMP. A cortactina é uma proteína associada ao citoesqueleto de actina, capaz de monitorar mudanças no citoesqueleto e no tráfego de membrana (BOWDEN et al., 2006; WEAVER, 2006). A MT1-MMP é uma metaloprotease (MMP) de membrana que está envolvida com a degradação da MEC, exercendo essa atividade nos invadopódios (ARTYM et al., 2006).

O gene humano EMS1, que codifica a proteína cortactina, está superexpresso em 29\% dos tumores de cabeça e pescoço (SCHUURING, 1995). Essa super-expressão está relacionada à migração, invasão e metástase em células tumorais (LI et al., 2001; CHUMA et al., 2004; PANTEL e BRAKENHOFF, 2004). Além disso, super-expressão de MT1-MMP em células tumorais promove vários eventos relacionados ao processo invasão in vitro e in vivo (HOTARY et al., 2003; ITOH e SEIKI, 2004; SABEH et al., 2004). Detectamos a expressão de cortactina e MT1-MMP no carcinoma adenóide cístico in vivo. Uma característica importante do carcinoma adenóide cístico é a invasão perineural e perivascular (BATSAKIS, 1980; SEIFERT e SOBIN, 1992; DARDICK, 1996; DARLING et al., 2002). De maneira interessante, cortactina e MT1-MMP foram encontradas em regiões próximas a vasos sanguíneos. Isso indica que os invadopódios podem contribuir diretamente para esse aspecto do carcinoma adenóide cístico. Além disso, já verificamos a marcação das proteínas cortactina e MT1-MMP nos invadopódios das células derivadas de carcinoma adenóide cístico (NASCIMENTO et al., 2009).

Durante muito tempo, as células neoplásicas foram o alvo de muitos estudos relacionados ao câncer. Contudo, já foi estabelecido que o estroma que circunda as neoplasias está diretamente relacionado ao seu comportamento biológico (LIOTTA e KOHN, 2001; DECLERCK et al., 2004; PEREIRA et al., 2005). De fato, o estroma contém tanto elementos celulares quanto não celulares capazes de modificar processos proliferativos e invasivos em células tumorais (WERNERT, 1997; LIOTTA e KOHN, 2001). 
A matriz extracelular (MEC) do estroma neoplásico é um arranjo macromolecular tridimensional, composto por como colágenos, glicoproteínas e proteoglicanas, com evidentes propriedades estruturais. Além disso, a MEC funciona como um reservatório de proteínas ligantes e fatores de crescimento que podem influenciar o destino celular, afetando crescimento, diferenciação, motilidade e viabilidade (DECLERCK et al., 2004; COMOGLIO e TRUSOLINO, 2005; TANZER, 2006).

Várias das moléculas que compõem a matriz extracelular e membrana basal apresentam em sua estrutura os chamados sítios matricrípticos ou matricriptinas. Esses sítios, dotados de funções biológicas, estão escondidos na estrutura de proteínas da MEC, e podem ser expostos através de proteólise, dando origem a fragmentos e peptídeos bioativos (FAISAL KHAN et al., 2002; SCHENK e QUARANTA, 2003; MOTT e WERB, 2004). Durante o processo de invasão, células neoplásicas são capazes de ultrapassar a membrana basal e estroma intersticial com auxílio de enzimas proteolíticas. Nesse momento, células tumorais podem ficar expostas a componentes da MEC, bem como a peptídeos bioativos, capazes de regular funções celulares (WILSON et al., 1999).

A lâmina basal, uma fina camada de MEC especializada, é produzida pelas células que estão na interface epitélio-tecido conjuntivo, e é muito importante em processos estruturais como suporte mecânico, polarização celular e compartimentalização de tecidos. Longe de ser uma estrutura inerte, a membrana basal também apresenta participação bastante ativa em funções celulares como morfogênese tecidual, adesão, migração, crescimento e diferenciação celulares (COLOGNATO e YURCHENCO, 2000; BOSMAN e STAMENKOVIC, 2003; YURCHENCO et al., 2004; SUZUKI et al., 2005).

As lamininas são glicoproteínas abundantemente expressas na membrana basal, formadas por três cadeias polipeptídicas ( $\alpha, \beta, \gamma)$ (COLOGNATO e YURCHENCO, 2000; MINER e YURCHENCO, 2004; AUMAILLEY et al., 2005; SUZUKI et al., 2005). Essa molécula possui múltiplos sítios matricrípticos vinculados a diferentes atividades biológicas incluindo adesão, migração, diferenciação, angiogênese e secreção de proteases (MALINDA e KLEINMAN, 1996; HOFFMAN et al., 1998; FREITAS e JAEGER, 2002; FREITAS et al., 2004; MORAIS FREITAS et al., 2007; GAMA-DE-SOUZA et al., 2008). A laminina-111 (antiga laminina-1) é a 
isoforma que apresenta o maior número de sequências biologicamente ativas já identificadas (NOMIZU et al., 1997b; NOMIZU et al., 1998). Nosso laboratório já demonstrou que tanto a laminina-111 quanto alguns de seus peptídeos bioativos, como YIGSR, SIKVAV, C16 e AG73 regulam fenótipo e atividades biológicas de linhagens celulares derivadas de carcinoma adenóide cístico (células CAC2) (DE OLIVEIRA et al., 2001; FRANCA et al., 2001; FREITAS e JAEGER, 2002; CAPUANO e JAEGER, 2004; FREITAS et al., 2004; FREITAS et al., 2007; MORAIS FREITAS et al., 2007; GAMA-DE-SOUZA, 2008; GAMA-DE-SOUZA et al., 2008).

Dentre os peptídeos da laminina-111 estudados, nesse trabalho nos interessamos em estudar o papel dos peptídeos, AG73 e C16 na atividade de invadopódios. Já verificamos que, AG73, promoveu adesão e atividade de protease em células de carcinoma adenóide cístico e mioepitelioma (GAMA-DE-SOUZA et al., 2008). C16 por sua vez, aumentou migração invasão e atividade de protease das células CAC2 (GAMA-DE-SOUZA, 2008). Os processos de migração, invasão e secreção de protease de células tumorais parecem ser conduzidos pelos invadopódios (AYALA et al., 2006). Nossos resultados demonstraram que ambos os peptídeos da laminina, AG73 e C16 aumentaram a atividade de invadopódio das células CAC2. Podemos inferir então que, os peptídeos da laminina teriam papel importante na regulação da atividade invasiva do carcinoma adenóide cístico.

Neoplasias de glândula salivar, como o carcinoma adenóide cístico, expressam proeminente membrana basal. Resultados do nosso Laboratório demonstraram que a membrana basal do carcinoma adenóide cístico está pelo menos 40 vezes mais espessada do que no tecido normal (GAMA-DE-SOUZA, 2008). Achados semelhantes foram observados por outros autores (TUNGGAL et al., 2002). Devido a esse espessamento, uma super produção de todos os componentes da membrana basal, como a laminina, pode ocorrer no carcinoma adenóide cístico in vivo, potencializando sua influência no comportamento do tumor.

Nossos experimentos realizados com células de glândula salivar normal (células HSG) corroboram com essa idéia, uma vez que os peptídeos da laminina não estimularam a atividade de invadopódios nessas células. Especulamos que essas células parecem formar podossomos observados pela marcação pontual de actina nos pequenos focos de digestão na gelatina fluorescente. Podemos também inferir, a partir desses dados, que os peptídeos da laminina-111 não seriam capazes, 
por si só, de estimular a carcinogênese. Isso porque, o papel deles seria uma consequência da expressão da laminina-111 no tecido tumoral. Uma vez que esse tipo de laminina no tecido normal adulto é escasso (EKBLOM et al., 1998; COLOGNATO e YURCHENCO, 2000; MINER e YURCHENCO, 2004).

Trabalhos na literatura estudam a dinâmica dos invadopódios através das proteínas cortactina e MT1-MMP (ARTYM et al., 2006; CLARK et al., 2007; CLARK e WEAVER, 2008; OSER et al., 2009). Dessa forma, para analisar de maneira mais crítica o efeito dos peptídeos da laminina na atividade de invadopódios nas células CAC2, também realizamos marcação para essas proteínas nas células tratadas com AG73 e C16 e crescidas sobre a gelatina fluorescente. Células tratadas por esses peptídeos também foram submetidas a "immunoblot". Não foi observada nenhuma diferença com relação a distribuição dessas proteínas nas células CAC2 tratadas pelos peptídeos. No entanto, "immunoblot" mostrou que os peptídeos AG73 e C16 promoveram aumento na expressão de MT1-MMP nessas células. Por outro lado, expressão de cortactina não foi alterada pelo tratamento com os peptídeos.

Estudos demonstram que a cortactina é importante não só para a estrutura dos invadopódios, como também para o tráfego de membrana, tendo papel na atividade de degradação dessas estruturas (ARTYM et al., 2006; CLARK et al., 2007). Segundo esses estudos, a cortactina serviria como um guia para atração de enzimas, como a MT1-MMP, para um local da membrana de íntimo contato com o substrato. Após o acúmulo de cortactina nesse local, ocorreria então o recrutamento da MT1-MMP e subsequente atividade de degradação (ARTYM et al., 2006). Além disso, outro estudo mostra que invadopódios ativos são verificados através da colocalização de cortactina e fosfotirosina (BOWDEN et al., 2006). Especulamos então que os peptídeos da laminina ativam algum tipo de sinalização intracelular, como por exemplo, fosforilação, capaz de direcionar a cortactina para regiões próximas a membrana. Não sendo necessária então, diferentemente do que ocorre com a MT1-MMP, uma nova síntese protéica da cortactina.

Consideramos os dados relacionados ao aumento da expressão de MT1MMP nas células tratadas pelos peptídeos extremamente relevantes, uma vez que autores já propuseram que a degradação de componentes da matriz poderia causar um mecanismo de retroalimentação positivo (CLARK et al., 2007). Esses dados vão de encontro com a nossa hipótese de que a degradação da laminina poderia causar 
liberação de seus peptídeos bioativos que, por sua vez, estimulariam maior expressão de MT1-MMP e consequentemente aumentariam a degradação do substrato.

Além disso, já foi verificado que além da MT1-MMP, outras MMPs, como a MMP9, podem ser recrutadas através do acúmulo de cortactina na membrana celular (CLARK et al., 2007). De maneira interessante, já verificamos que essa enzima é importante nas etapas iniciais da atividade de degradação do substrato nas células CAC2 (NASCIMENTO et al., 2009).

As MMPs têm papel chave na degradação da MEC e podem ser reguladas via ERK1/2. Essa via de sinalização também é importante na formação de invadopódios em células de melanoma (TAGUE et al., 2004). Já demonstramos que ERK regula secreção de MMPs em células CAC2, induzida por outro peptídeo da laminina, o SIKVAV (FREITAS et al., 2007). Nesse trabalho, células CAC2 foram tratadas com o inibidor U0126 e posteriormente submetidas a ensaio de zimografia. Células tratadas com inibidor apresentaram diminuição na atividade das MMPs 2 e 9. Realizamos ensaio de degradação de gelatina fluorescente com células inibidas para ERK com o mesmo reagente. Nossos resultados demonstraram que a inibição da via ERK foi específica e causou diminuição na atividade de invadopódio induzida pelos dois peptídeos, AG73 e C16.

Verificamos também o papel da via de sinalização Rac na atividade de invadopódio induzida por AG73 e C16. Rac pertence à família das GTPases Rho, que estão relacionadas a diversas funções celulares que envolvem mudanças morfológicas através de filamentos de actina, como migração (TAKAl et al., 1995). Cada subfamília parece exercer um papel específico nesses eventos. Rho está particularmente envolvida com a formação de fibras de stress em diversos tipos celulares (TAKAl et al., 1995). Rac regula formação de lamelipódios e "ruffling" de membrana, e Cdc42 regula formação de filopódios (HALL, 1998). Embora já tenha sido estabelecido o papel de cada uma das GTPases Rho nas fibras de stress, nos lamelipódios e nos filopódios, não existem até o momento, dados experimentais que apontem o papel exclusivamente de uma das GTPases Rho nos invadopódios. Por outro lado, duas GTPases têm sido relacionadas a essas estruturas a Cdc42 e Rac (NAKAHARA et al., 2003; SCHLUNCK et al., 2004; YAMAGUCHI et al., 2005; FURMANIAK-KAZMIERCZAK et al., 2007; PICHOT et al., 2010; HU et al., 2011). 
Utilizamos o reagente NSC23766 para analisar o papel da via Rac1 na atividade de invadopódios das células CAC2, mediada pelos peptídeos da laminina. Nossos experimentos demonstraram que a inibição da via Rac causou uma diminuição significante na atividade de invadopódio induzida pelo peptídeo AG73. No entanto, inibição de Rac1 não afetou a degradação do substrato induzida por C16. Nós presumimos então que, a via Rac1 está envolvida nos sinais gerados pelo peptídeo AG73, mas não pelos gerados por C16. No entanto, é importante comentar a limitação da técnica, uma vez que o NSC23766 é capaz de inibir competitivamente a ativação de Rac1 por dois de seus GEFs, TrioN e Tiam1 (GAO et al., 2004). Dessa forma, é possível que Rac1 regulada por outros GEFs, esteja sendo ativada, no caso do peptídeo C16. Portanto, mesmo após a utilização de NSC23766 pode haver participação de outros GEFs na ativação de Rac1. Esse pode ser um dos motivos pelo qual, não verificamos o envolvimento de Rac1 nos sinais gerados pelo peptídeo C16.

Resolvemos investigar também receptores relacionados aos efeitos de AG73 e C16 nas células CAC2. Integrinas são os principais receptores para laminina e medeiam adesão celular, migração e diferenciação (PATARROYO et al., 2002). Além disso, a interação entre lamininas e integrinas pode ser específica. Já foi verificado que a integrina $\alpha 6 \beta 1$ interage com a laminina-111 na região do domínio globular (MERCURIO, 1995). Outro dado interessante envolveu cromatografia de afinidade que mostrou que o peptídeo C16 parece interagir com integrina- $\beta 1$ (PONCE et al., 2001).

Em nosso Laboratório, já demonstramos que integrinas regulam efeitos de diferentes peptídeos da laminina em tumores de glândula salivar (FREITAS et al., 2007; GAMA-DE-SOUZA et al., 2008). Além disso, as integrinas estão entre as principais moléculas relacionadas à atividade adesão dos invadopódios (LINDER e AEPFELBACHER, 2003; BUCCIONE et al., 2004). Autores têm apontado a integrina $\beta 1$ como principal receptor (STYLLI et al., 2008). Esses achados nos levaram a estudar se a subunidade $\beta 1$ da integrina regularia a atividade de invadopódio induzida pelos peptídeos da laminina nas células CAC2.

Gama-de-Souza et al. (2008) verificaram que a inibição de integrina $\beta 1$ diminuiu a atividade de protease nas células CAC2. Sabe-se o processo de invasão 
se dá pela secreção de enzimas proteolíticas pelas células neoplásicas que assim são capazes de degradar a membrana basal e estroma intersticial. Demonstramos que a inibição da subunidade $\beta 1$ da integrina causou uma diminuição na atividade de invadopódios induzidos por AG73 e C16. Nossos resultados sugerem que a subunidade $\beta 1$ da integrina pode participar da sinalização dos peptídeos da laminina, influenciando o comportamento invasivo das células CAC2.

Nossos dados experimentais não nos permitem propor uma correlação entre a integrina $\beta 1$ e as vias de sinalização ERK e Rac na formação de invadopódios nas células CAC2. No entanto, a hipótese de que os peptídeos da laminina poderiam se ligar a integrina $\beta 1$ e ativar as vias de sinalização ERK e Rac culminando da formação de invadopódios, não pode ser descartada. Isso porque é sabido que ambas as vias podem ser ativadas pelas integrinas (CHEN et al., 1994; SCHLAEPFER et al., 1994; ZHU e ASSOIAN, 1995; PRICE et al., 1998; O'CONNOR et al., 2000; BERRIER et al., 2002; HIRSCH et al., 2002). Por outro lado, também existe a hipótese de que essas moléculas, integrina $\beta 1$, ERK e Rac podem agir de maneira independe na formação de invadopódios nas células CAC2.

Dados recentes da literatura têm relacionado os processos de invasão e metástase de células tumorais com as protrusões de membrana ricas em actina, denominadas invadopódios. Embora muitos avanços já tenham sido feitos com relação ao estudo dos invadopódios, muitas questões ainda não estão esclarecidas. Dentro desse contexto, esperamos aprofundar os conhecimentos obtidos até o momento sobre a dinâmica e a função dos invadopódios, estudando o efeito biológico dos peptídeos da laminina-111 nessas estruturas. Consideramos esse estudo importante para a compreensão da biologia tumoral do carcinoma adenóide cístico, uma vez que se trata de uma neoplasia maligna com alto grau de recorrência e metástase á distância. Com base nos nossos dados experimentais propomos que, AG73 e C16 aumentam atividade de invadopódios em uma linhagem celular derivada de carcinoma adenóide cístico humano, através da subunidade $\beta 1$ da integrina. ERK1/2 participa dos sinais gerados por ambos os peptídeos, enquanto que a via Rac1 está relacionada aos efeitos do peptídeo AG73. 


\section{CONCLUSÕES}

Baseados nos resultados dos experimentos realizados, concluímos que:

1) As proteínas coractina e MT1-MMP são expressas in vivo no carcinoma adenóide cístico;

2) AG73 e C16 induzem aumento na atividade de invadopódios nas células CAC2;

3) AG73 e C16 induzem aumento de expressão da enzima MT1-MMP nas células $\mathrm{CAC2}$;

4) A atividade de invadopódio induzidas por AG73 e C16 tem participação da subunidade $\beta 1$ da integrina;

5) Os sinais gerados por $A G 73$ e C16 são tranduzidos por ERK 1/2;

6) Os sinais gerados por AG73 são tranduzidos por Rac1. 


\section{REFERÊNCIAS ${ }^{1}$}

ALEXANDER, N. R. et al. Extracellular matrix rigidity promotes invadopodia activity. Curr. Biol., v. 18, n. 17, p. 1295-1299, 2008.

ALEXANDROVA, A. Y. Evolution of cell interactions with extracellular matrix during carcinogenesis. Biochemistry (Mosc.), v. 73, n. 7, p. 733-741, 2008.

ANGERS-LOUSTAU, A. et al. SRC regulates actin dynamics and invasion of malignant glial cells in three dimensions. Mol. Cancer Res., v. 2, n. 11, p. 595-605, 2004.

ARTYM, V. V. et al. Dynamic membrane remodeling at invadopodia differentiates invadopodia from podosomes. Eur. J. Cell Biol., v. 90, n. 2-3, p. 172-180, 2011.

ARTYM, V. V. et al. Dynamic interactions of cortactin and membrane type 1 matrix metalloproteinase at invadopodia: defining the stages of invadopodia formation and function. Cancer Res., v. 66, n. 6, p. 3034-3043, 2006.

AUMAILLEY, M. Structure and supramolecular organization of basement membranes. Kidney Int. Suppl., v. 49, p. 4-7, 1995.

AUMAILLEY, M. et al. A simplified laminin nomenclature. Matrix Biol., v. 24, n. 5, p. 326332, 2005.

AUMAILLEY, M.; SMYTH, N. The role of laminins in basement membrane function. J. Anat., v. 193, p. 1-21, 1998.

AYALA, I. et al. Invadopodia: a guided tour. Eur. J. Cell Biol., v. 85, n. 3-4, p. 159-164, 2006.

AYALA, I. et al. Multiple regulatory inputs converge on cortactin to control invadopodia biogenesis and extracellular matrix degradation. J. Cell Sci., v. 121, n. 3, p. 369-378, 2008.

BALDASSARRE, M. et al. Dynamin participates in focal extracellular matrix degradation by invasive cells. Mol. Biol. Cell, v. 14, n. 3, p. 1074-1084, 2003.

BASBAUM, C. B.; WERB, Z. Focalized proteolysis: spatial and temporal regulation of extracellular matrix degradation at the cell surface. Curr. Opin. Cell Biol., v. 8, n. 5, p. 731738, 1996.

BATSAKIS, J. G. Salivary gland neoplasia: an outcome of modified morphogenesis and cytodifferentiation. Oral Surg. Oral Med. Oral Pathol., v. 49, n. 3, p. 229-232, 1980.

BERRIER, A. L. et al. The integrin beta tail is required and sufficient to regulate adhesion signaling to Rac1. J. Cell Sci., v. 115, n. 22, p. 4285-4291, 2002.

BIANCHI, B. et al. Adenoid cystic carcinoma of intraoral minor salivary glands. Oral Oncol., v. 44 , n. 11 , p. 1026-1031, 2008.

BOSMAN, F. T. et al. Basement membranes in neoplasia. Prog. Histochem. Cytochem., v. 24, n. 4, p. 1-92, 1992.

\footnotetext{
${ }^{1}$ De acordo com:

ASSOCIAÇÃO BRASILEIRA DE NORMAS TÉCNICAS. NBR 6023: informação e documentação: referências: elaboração. Rio de Janeiro, 2002.
} 
BOSMAN, F. T.; STAMENKOVIC, I. Functional structure and composition of the extracellular matrix. J. Pathol., v. 200, n. 4, p. 423-428, 2003.

BOUDREAU, N.; BISSELL, M. J. Extracellular matrix signaling: integration of form and function in normal and malignant cells. Curr. Opin. Cell Biol., v. 10, n. 5, p. 640-646, 1998.

BOUKHERIS, $\mathrm{H}$. et al. Incidence of carcinoma of the major salivary glands according to the WHO classification, 1992 to 2006: a population-based study in the United States. Cancer Epidemiol Biomarkers Prev, v. 18, n. 11, p. 2899-2906, 2009.

BOWDEN, E. T. et al. An invasion-related complex of cortactin, paxillin and PKCmu associates with invadopodia at sites of extracellular matrix degradation. Oncogene, v. 18, n. 31, p. 4440-4449, 1999.

BOWDEN, E. T. et al. Co-localization of cortactin and phosphotyrosine identifies active invadopodia in human breast cancer cells. Exp. Cell Res., v. 312, n. 8, p. 1240-1253, 2006.

BRADLEY, P. J. Adenoid cystic carcinoma of the head and neck: a review. Curr. Opin. Otolaryngol. Head Neck Surg., v. 12, n. 2, p. 127-132, 2004.

BRYCE, N. S. et al. Cortactin promotes cell motility by enhancing lamellipodial persistence. Curr. Biol., v. 15, n. 14, p. 1276-1285, 2005.

BUCCIONE, R. et al. Foot and mouth: podosomes, invadopodia and circular dorsal ruffles. Nat. Rev. Mol. Cell Biol., v. 5, n. 8, p. 647-657, 2004.

BUCHNER, A. et al. Relative frequency of intra-oral minor salivary gland tumors: a study of 380 cases from northern California and comparison to reports from other parts of the world. J. Oral. Pathol. Med., v. 36, n. 4, p. 207-214, 2007.

BURGESON, R. E. et al. A new nomenclature for the laminins. Matrix Biol., v. 14, n. 3, p. 209-211, 1994.

BUTLER, G. S. et al. The TIMP2 membrane type 1 metalloproteinase "receptor" regulates the concentration and efficient activation of progelatinase A. A kinetic study. J. Biol. Chem., v. 273 , n. 2, p. 871-880, 1998.

$\mathrm{CAO}$, J. et al. Distinct roles for the catalytic and hemopexin domains of membrane type 1matrix metalloproteinase in substrate degradation and cell migration. J. Biol. Chem., v. 279, n. 14, p. 14129-14139, 2004.

CAPUANO, A. C.; JAEGER, R. G. The effect of laminin and its peptide SIKVAV on a human salivary gland myoepithelioma cell line. Oral Oncol., v. 40, n. 1, p. 36-42, 2004.

CHAMBERS, A. F. et al. Dissemination and growth of cancer cells in metastatic sites. Nat. Rev. Cancer, v. 2, n. 8, p. 563-572, 2002.

CHARONIS, A. S. et al. A novel synthetic peptide from the B1 chain of laminin with heparinbinding and cell adhesion-promoting activities. J. Cell Biol., v. 107, n. 3, p. 1253-1260, 1988.

CHAUDHRY, A. P. et al. Histogenesis of adenoid cystic carcinoma of the salivary glands. Light and electronmicroscopic study. Cancer, v. 58, n. 1, p. 72-82, 1986. 
CHEN, Q. et al. Integrin-mediated cell adhesion activates mitogen-activated protein kinases. J. Biol. Chem., v. 269, n. 43, p. 26602-26605, 1994.

CHEN, W. T. Proteolytic activity of specialized surface protrusions formed at rosette contact sites of transformed cells. J. Exp. Zool., v. 251, n. 2, p. 167-185, 1989.

CHEN, W. T. Proteases associated with invadopodia, and their role in degradation of extracellular matrix. Enzyme Protein., v. 49, n. 1-3, p. 59-71, 1996.

CHEN, W. T. et al. Local degradation of fibronectin at sites of expression of the transforming gene product pp60src. Nature, v. 316, n. 6024, p. 156-158, 1985.

CHEN, W. T.; WANG, J. Y. Specialized surface protrusions of invasive cells, invadopodia and lamellipodia, have differential MT1-MMP, MMP-2, and TIMP-2 localization. Ann. N. Y. Acad. Sci., v. 878, p. 361-371, 1999.

CHENG, J. et al. Biosynthesis of basement membrane molecules by salivary adenoid cystic carcinoma cells: an immunofluorescence and confocal microscopic study. Virchows Arch., v. 426 , n. 6 , p. 577-586, 1995.

CHENG, J. et al. Basement membranes in adenoid cystic carcinoma. An immunohistochemical study. Cancer, v. 69, n. 11, p. 2631-2640, 1992.

CHUMA, M. et al. Overexpression of cortactin is involved in motility and metastasis of hepatocellular carcinoma. J. Hepatol., v. 41, n. 4, p. 629-636, 2004.

CHUMMUN, S. et al. Adenoid cystic carcinoma of the head and neck. Br. J. Plast. Surg., v. 54, n. 6, p. 476-480, 2001.

CLARK, E. S.; WEAVER, A. M. A new role for cortactin in invadopodia: regulation of protease secretion. Eur. J. Cell Biol., v. 87, n. 8-9, p. 581-590, 2008.

CLARK, E. S. et al. Cortactin is an essential regulator of matrix metalloproteinase secretion and extracellular matrix degradation in invadopodia. Cancer Res., v. 67, n. 9, p. 4227-4235, 2007.

COLOGNATO, H.; YURCHENCO, P. D. Form and function: the laminin family of heterotrimers. Dev. Dyn., v. 218, n. 2, p. 213-234, 2000.

COMOGLIO, P. M.; TRUSOLINO, L. Cancer: the matrix is now in control. Nat. Med., v. 11, n. 11, p. 1156-1159, 2005.

CONDEELIS, J.; SEGALL, J. E. Intravital imaging of cell movement in tumours. Nat. Rev. Cancer, v. 3, n. 12, p. 921-930, 2003.

COOPMAN, P. J. et al. Phagocytosis of cross-linked gelatin matrix by human breast carcinoma cells correlates with their invasive capacity. Clin. Cancer Res., v. 4, n. 2, p. 507$515,1998$.

D'ARDENNE, A. J. et al. Laminin and fibronectin in adenoid cystic carcinoma. J. Clin. Pathol., v. 39, n. 2, p. 138-144, 1986.

DA CRUZ PEREZ, D. E. et al. Prognostic factors in head and neck adenoid cystic carcinoma. Oral Oncol., v. 42, n. 2, p. 139-146, 2006. 
DALY, R. J. Cortactin signalling and dynamic actin networks. Biochem. J., v. 382, n. 1, p. 13-25, 2004.

DARDICK, I. Salivary Gland Tumor Pathology. New York: Igaku-Shoin 1996

DARLING, M. R. et al. Bilateral submandibular salivary gland swelling--a report of chronic sialodochitis with eosinophilia. S.A.D.J., v. 57, n. 3, p. 104-106, 2002.

DAVIS, G. E. et al. Regulation of tissue injury responses by the exposure of matricryptic sites within extracellular matrix molecules. Am. J. Pathol., v. 156, n. 5, p. 1489-1498, 2000.

DE OLIVEIRA, P. T. et al. The effect of a reconstituted basement membrane (matrigel) on a human salivary gland myoepithelioma cell line. Virchows Arch., v. 439, n. 4, p. 571-578, 2001.

DECLERCK, Y. A. et al. Proteases, extracellular matrix, and cancer: a workshop of the path B study section. Am. J. Pathol., v. 164, n. 4, p. 1131-1139, 2004.

DERYUGINA, E. I.; QUIGLEY, J. P. Matrix metalloproteinases and tumor metastasis. Cancer Metastasis Rev., v. 25, n. 1, p. 9-34, 2006.

DERYUGINA, E. I. et al. MT1-MMP initiates activation of pro-MMP-2 and integrin alphavbeta3 promotes maturation of MMP-2 in breast carcinoma cells. Exp. Cell Res., v. 263, n. 2, p. 209-223, 2001.

DESAI, B. et al. Invadopodia and matrix degradation, a new property of prostate cancer cells during migration and invasion. J. Biol. Chem., v. 283, n. 20, p. 13856-13866, 2008.

EGEBLAD, M.; WERB, Z. New functions for the matrix metalloproteinases in cancer progression. Nat. Rev. Cancer, v. 2, n. 3, p. 161-174, 2002.

EKBLOM, M. et al. Laminin isoforms and epithelial development. Ann. N. Y. Acad. Sci., v. 857, p. 194-211, 1998.

EKBLOM, P. Receptors for laminins during epithelial morphogenesis. Curr. Opin. Cell Biol., v. 8, n. 5, p. 700-706, 1996.

EKBLOM, P. et al. Expression and biological role of laminin-1. Matrix Biol., v. 22, n. 1, p. 3547, 2003.

ENGBRING, J. A. et al. The B16F10 cell receptor for a metastasis-promoting site on laminin1 is a heparan sulfate/chondroitin sulfate-containing proteoglycan. Cancer Res., v. 62, n. 12 , p. 3549-3554, 2002.

ENGBRING, J. A. et al. The laminin alpha-1 chain derived peptide, AG73, increases fibronectin levels in breast and melanoma cancer cells. Clin. Exp. Metastasis, v. 25, n. 3, p. 241-252, 2008.

EPSTEIN, J. B.; SCHUBERT, M. M. Oropharyngeal mucositis in cancer therapy. Review of pathogenesis, diagnosis, and management. Oncology (Williston Park), v. 17, n. 12, p. 1767-1779, 2003.

ETIENNE-MANNEVILLE, S.; HALL, A. Rho GTPases in cell biology. Nature, v. 420, n. 6916, p. 629-635, 2002. 
EVERSOLE, L. R. Histogenic classification of salivary tumors. Arch. Pathol., v. 92, n. 6, p. 433-443, 1971.

EVESON, J. W.; CAWSON, R. A. Tumours of the minor (oropharyngeal) salivary glands: a demographic study of 336 cases. J. Oral. Pathol. Med., v. 14, n. 6, p. 500-509, 1985.

FAISAL KHAN, K. M. et al. Exposure of cryptic domains in the alpha 1-chain of laminin-1 by elastase stimulates macrophages urokinase and matrix metalloproteinase- 9 expression. $\mathbf{J}$. Biol. Chem., v. 277, n. 16, p. 13778-13786, 2002.

FRAME, M. C. Newest findings on the oldest oncogene; how activated src does it. J. Cell. Sci., v. 117, n. Pt 7, p. 989-998, 2004.

FRANCA, C. M. et al. The role of basement membrane proteins on the expression of neural cell adhesion molecule (N-CAM) in an adenoid cystic carcinoma cell line. Oral Oncol., v. 36, n. 2, p. 248-252, 2000.

FRANCA, C. M. et al. Effect of N-CAM on in vitro invasion of human adenoid cystic carcinoma cells. Oral Oncol., v. 37, n. 8, p. 638-642, 2001.

FREITAS, V. M.; JAEGER, R. G. The effect of laminin and its peptide SIKVAV on a human salivary gland adenoid cystic carcinoma cell line. Virchows Arch., v. 441, n. 6, p. 569-576, 2002.

FREITAS, V. M. et al. Laminin-1 and SIKVAV a laminin-1-derived peptide, regulate the morphology and protease activity of a human salivary gland adenoid cystic carcinoma cell line. Oral Oncol., v. 40, n. 5, p. 483-489, 2004.

FREITAS, V. M. et al. SIKVAV, a laminin alpha1-derived peptide, interacts with integrins and increases protease activity of a human salivary gland adenoid cystic carcinoma cell line through the ERK 1/2 signaling pathway. Am. J. Pathol., v. 171, n. 1, p. 124-138, 2007.

FRIEDL, P.; WOLF, K. Tumour-cell invasion and migration: diversity and escape mechanisms. Nat. Rev. Cancer, v. 3, n. 5, p. 362-374, 2003.

FRIEDMAN, E. W.; SCHWARTZ, A. E. Diagnosis of salivary gland tumors. C.A. Cancer J. Clin., v. 24, n. 5, p. 266-273, 1974.

FURMANIAK-KAZMIERCZAK, $\mathrm{E}$. et al. Formation of extracellular matrix-digesting invadopodia by primary aortic smooth muscle cells. Circ. Res., v. 100, n. 9, p. 1328-1336. 2007.

GAMA-DE-SOUZA, L. N. Peptídeo C16 derivado da laminina regula migração, invasão e secreção de protease em linhagem celular derivada de carcinoma adenóide cístico humano através de integrinas e das vias de sinalização AKT e ERK. 2008. 123 f. Tese (Doutorado em Biologia Celular e Tecidual) - Instituto de Ciências Biomédicas, Universidade de São Paulo, São Paulo, 2008.

GAMA-DE-SOUZA, L. N. et al. Adhesion and protease activity in cell lines from human salivary gland tumors are regulated by the laminin-derived peptide AG73, syndecan-1 and beta1 integrin. Matrix Biol., v. 27, n. 5, p. 402-419, 2008.

GAO, Y. et al. Rational design and characterization of a Rac GTPase-specific small molecule inhibitor. Proc. Natl. Acad. Sci. U. S. A., v. 101, n. 20, p. 7618-7623, 2004. 
GARDEN, A. S. et al. The influence of positive margins and nerve invasion in adenoid cystic carcinoma of the head and neck treated with surgery and radiation. Int. J. Radiat. Oncol. Biol. Phys., v. 32, n. 3, p. 619-626, 1995.

GHOSH, S.; STACK, M. S. Proteolytic modification of laminins: functional consequences. Microsc. Res. Tech., v. 51, n. 3, p. 238-246, 2000.

GRAF, J. et al. A pentapeptide from the laminin B1 chain mediates cell adhesion and binds the 67,000 laminin receptor. Biochemistry, v. 26, n. 22, p. 6896-6900, 1987.

GRANT, D. S. et al. Interaction of endothelial cells with a laminin A chain peptide (SIKVAV) in vitro and induction of angiogenic behavior in vivo. J. Cell. Physiol., v. 153, n. 3, p. 614625, 1992.

GRUNERT, S. et al. Diverse cellular and molecular mechanisms contribute to epithelial plasticity and metastasis. Nat. Rev. Mol. Cell Biol., v. 4, n. 8, p. 657-665, 2003.

GUDJONSSON, T. et al. Normal and tumor-derived myoepithelial cells differ in their ability to interact with luminal breast epithelial cells for polarity and basement membrane deposition. $\mathbf{J}$. Cell Sci., v. 115, pt. 1, p. 39-50, 2002.

GUZZO, M. et al. Major and minor salivary gland tumors. Crit. Rev. Oncol. Hematol., v. 74, n. 2, p. 134-148, 2010.

HALL, A. Rho GTPases and the actin cytoskeleton. Science, v. 279, n. 5350, p. 509-514, 1998.

HANDSLEY, M. M.; EDWARDS, D. R. Metalloproteinases and their inhibitors in tumor angiogenesis. Int. J. Cancer, v. 115, n. 6, p. 849-860, 2005.

HASHIMOTO, S. et al. Requirement for Arf6 in breast cancer invasive activities. Proc. Natl. Acad. Sci. U. S. A., v. 101, n. 17, p. 6647-6652, 2004.

$\mathrm{HIRSCH}$, E. et al. Defective Rac-mediated proliferation and survival after targeted mutation of the beta1 integrin cytodomain. J. Cell. Biol., v. 157, n. 3, p. 481-492, 2002.

HOFFMAN, M. P. et al. Cell type-specific differences in glycosaminoglycans modulate the biological activity of a heparin-binding peptide (RKRLQVQLSIRT) from the G domain of the laminin alpha1 chain. J. Biol. Chem., v. 276, n. 25, p. 22077-22085, 2001.

HOFFMAN, M. P. et al. Laminin-1 and laminin-2 G-domain synthetic peptides bind syndecan-1 and are involved in acinar formation of a human submandibular gland cell line. $\mathbf{J}$. Biol. Chem., v. 273, n. 44, p. 28633-28641, 1998.

HOFMANN, U. B. et al. Expression of matrix metalloproteinases in the microenvironment of spontaneous and experimental melanoma metastases reflects the requirements for tumor formation. Cancer Res., v. 63, n. 23, p. 8221-8225, 2003.

HOFMANN, U. B. et al. Role of matrix metalloproteinases in melanoma cell invasion. Biochimie, v. 87, n. 3-4, p. 307-314, 2005.

HOHENESTER, E.; ENGEL, J. Domain structure and organisation in extracellular matrix proteins. Matrix Biol., v. 21, n. 2, p. 115-128, 2002. 
HOSOKAWA, Y. et al. Significant role of laminin-1 in branching morphogenesis of mouse salivary epithelium cultured in basement membrane matrix. Dev. Growth Differ., v. 41, n. 2, p. 207-216, 1999.

HOTARY, K. et al. A cancer cell metalloprotease triad regulates the basement membrane transmigration program. Genes Dev., v. 20, n. 19, p. 2673-2686, 2006.

HOTARY, K. B. et al. Membrane type I matrix metalloproteinase usurps tumor growth control imposed by the three-dimensional extracellular matrix. Cell, v. 114, n. 1, p. 33-45, 2003.

HOTTE, S. J. et al. Imatinib mesylate in patients with adenoid cystic cancers of the salivary glands expressing c-kit: a Princess Margaret Hospital phase II consortium study. J. Clin. Oncol., v. 23, n. 3, p. 585-590, 2005.

HOZUMI, K. et al. Mixed peptide-chitosan membranes to mimic the biological activities of a multifunctional laminin alpha1 chain LG4 module. Biomaterials, v. 30, n. 8, p. 1596-1603, 2009.

$\mathrm{HU}$, J. et al. Cdc42-interacting protein 4 is a Src substrate that regulates invadopodia and invasiveness of breast tumors by promoting MT1-MMP endocytosis. J. Cell. Sci., v. 124, n. Pt 10, p. 1739-1751, 2011.

HUANG, M. et al. Factors influencing survival rate in adenoid cystic carcinoma of the salivary glands. Int. J. Oral. Maxillofac. Surg., v. 26, n. 6, p. 435-439, 1997.

IKEMOTO, S. et al. Laminin peptide-conjugated chitosan membrane: Application for keratinocyte delivery in wounded skin. J. Biomed. Mater. Res. A., v. 79, n. 3, p. 716-722, 2006.

INSTITUTO NACIONAL DO CÂNCER. Estimativa 2008: Incidência de Câncer no Brasil. Rio de Janeiro: Ministério da Saúde. 2007. 94 p.

ITO, B. et al. Diagnosis of the depth of invasion of esophageal carcinoma using digital radiography. Eur. J. Radiol., v. 54, n. 3, p. 377-382, 2005.

$\mathrm{ITOH}, \mathrm{Y}$. et al. The second dimer interface of MT1-MMP, the transmembrane domain, is essential for ProMMP-2 activation on the cell surface. J. Biol. Chem., v. 283, n. 19, p. 13053-13062, 2008.

ITOH, Y.; SEIKI, M. MT1-MMP: an enzyme with multidimensional regulation. Trends Biochem. Sci., v. 29, n. 6, p. 285-289, 2004.

IWAMOTO, Y. et al. YIGSR, a synthetic laminin pentapeptide, inhibits experimental metastasis formation. Science, v. 238, n. 4830, p. 1132-1134, 1987.

JAEGER, M. M. et al. Effect of spatial arrangement of the basement membrane on cultured pleomorphic adenoma cells. Study by immunocytochemistry and electron and confocal microscopy. Virchows Arch., v. 430, n. 6, p. 467-477, 1997.

JAEGER, R. G. et al. Secretion of collagen I and tenascin is modulated by laminin-111 in 3D culture of human adenoid cystic carcinoma cells. Int. J. Exp. Pathol., v. 89, n. 2, p. 98-105, 2008.

JAFFE, A. B.; HALL, A. Rho GTPases: biochemistry and biology. Annu. Rev. Cell Dev. Biol., v. 21, p. 247-269, 2005. 
KADLER, K. E. et al. Collagen fibril formation. Biochem. J., v. 316, p. 1-11, 1996.

KADOYA, Y. et al. Laminin alpha1 chain $G$ domain peptide, RKRLQVQLSIRT, inhibits epithelial branching morphogenesis of cultured embryonic mouse submandibular gland. Dev. Dyn., v. 212, n. 3, p. 394-402, 1998.

KADOYA, Y.; YAMASHINA, S. Salivary gland morphogenesis and basement membranes. Anat. Sci. Int., v. 80, n. 2, p. 71-79, 2005.

KANEMOTO, T. et al. Identification of an amino acid sequence from the laminin A chain that stimulates metastasis and collagenase IV production. Proc. Natl. Acad. Sci. U. S. A., v. 87, n. 6, p. 2279-2283, 1990.

KHAN, A. J. et al. Adenoid cystic carcinoma: a retrospective clinical review. Int. J. Cancer, v. 96, n. 3, p. 149-158, 2001.

$\mathrm{KIM}$, W. $\quad H$. et al. Laminin-alpha1-chain sequence Leu-Gln-Val-Gln-Leu-Ser-Ile-Arg (LQVQLSIR) enhances murine melanoma cell metastases. Int. J. Cancer, v. 77, n. 4, p. 632639, 1998.

KINOSHITA, T. et al. TIMP-2 promotes activation of progelatinase A by membrane-type 1 matrix metalloproteinase immobilized on agarose beads. J. Biol. Chem., v. 273, n. 26, p. 16098-16103, 1998.

KLEINMAN, H. K. et al. Basement membrane complexes with biological activity. Biochemistry, v. 25, n. 2, p. 312-318, 1986.

KLEINMAN, H. K. et al. Role of the extracellular matrix in morphogenesis. Curr. Opin. Biotechnol., v. 14, n. 5, p. 526-532, 2003.

$\mathrm{KO}, \mathrm{Y} . \mathrm{H}$. et al. Prognostic factors affecting the clinical outcome of adenoid cystic carcinoma of the head and neck. Jpn. J. Clin. Oncol., v. 37, n. 11, p. 805-811, 2007.

KOKEMUELLER, $\mathrm{H}$. et al. Adenoid cystic carcinoma of the head and neck--a 20 years experience. Int. J. Oral Maxillofac. Surg., v. 33, n. 1, p. 25-31, 2004.

KOSMEHL, $\mathrm{H}$. et al. Distribution of laminin and fibronectin isoforms in oral mucosa and oral squamous cell carcinoma. Br. J. Cancer, v. 81, n. 6, p. 1071-1079, 1999.

KURATOMI, Y. et al. Laminin gamma 1 chain peptide, C-16 (KAFDITYVRLKF), promotes migration, MMP-9 secretion, and pulmonary metastasis of B16-F10 mouse melanoma cells. Br. J. Cancer, v. 86, n. 7, p. 1169-1173, 2002.

KUTLESA, S. et al. Developmentally regulated interactions of human thymocytes with different laminin isoforms. Immunology, v. 105, n. 4, p. 407-418, 2002.

LANDIS, S. H. et al. Cancer statistics, 1999. C. A. Cancer J. Clin., v. 49, n. 1, p. 8-31, 1999.

$\mathrm{LI}, \mathrm{H}$. et al. Tumor microenvironment: the role of the tumor stroma in cancer. J. Cell. Biochem., v. 101, n. 4, p. 805-815, 2007.

LI, Y. et al. Cortactin potentiates bone metastasis of breast cancer cells. Cancer Res., v. 61, n. 18, p. 6906-6911, 2001. 
LINDER, S. The matrix corroded: podosomes and invadopodia in extracellular matrix degradation. Trends Cell Biol., v. 17, n. 3, p. 107-117, 2007.

LINDER, S.; AEPFELBACHER, M. Podosomes: adhesion hot-spots of invasive cells. Trends Cell Biol., v. 13, n. 7, p. 376-385, 2003.

LINDER, S.; KOPP, P. Podosomes at a glance. J .Cell Sci., v. 118, n. 10, p. 2079-2082, 2005.

LIOTTA, L. A.; KOHN, E. C. The microenvironment of the tumour-host interface. Nature, v. 411, n. 6835, p. 375-379, 2001.

LO, H. W. et al. Epidermal growth factor receptor cooperates with signal transducer and activator of transcription 3 to induce epithelial-mesenchymal transition in cancer cells via upregulation of TWIST gene expression. Cancer Res., v. 67, n. 19, p. 9066-9076, 2007.

LORENZ, M. et al. Imaging sites of $\mathrm{N}$-wasp activity in lamellipodia and invadopodia of carcinoma cells. Curr. Biol., v. 14, n. 8, p. 697-703, 2004.

LOYOLA, A. M. et al. Minor salivary gland tumours. A retrospective study of 164 cases in a Brazilian population. Eur. J. Cancer B. Oral. Oncol., v. 31B, n. 3, p. 197-201, 1995.

LUGASSY, C. et al. C16 laminin peptide increases angiotropic extravascular migration of human melanoma cells in a shell-less chick chorioallantoic membrane assay. $\mathbf{B r}$. $\mathbf{J}$. Dermatol., v. 157, n. 4, p. 780-782, 2007.

MACIEJEWSKI, A. et al. Outcome of surgery for adenoid cystic carcinoma of head and neck region. J. Craniomaxillofac. Surg., v. 30, n. 1, p. 59-61, 2002.

MALINDA, K. M.; KLEINMAN, H. K. The laminins. Int. J. Biochem. Cell Biol., v. 28, n. 9, p. 957-959, 1996.

MALINDA, K. M. et al. Angiogenic laminin-derived peptides stimulate wound healing. Int. J. Biochem. Cell Biol., v. 40, n. 12, p. 2771-2780, 2008.

MAO, Y.; SCHWARZBAUER, J. E. Fibronectin fibrillogenesis, a cell-mediated matrix assembly process. Matrix Biol., v. 24, n. 6, p. 389-399, 2005.

MARASTONI, S. et al. Extracellular matrix: a matter of life and death. Connect. Tissue Res., v. 49, n. 3, p. 203-206, 2008.

MARQUES, M. M. et al. Effect of Matrigel on adenoid cystic carcinoma cell line differentiation. Int. J. Exp. Pathol., v. 87, n. 6, p. 405-410, 2006.

MARTIN, G. R.; TIMPL, R. Laminin and other basement membrane components. Annu. Rev. Cell Biol., v. 3, p. 57-85, 1987.

MARTINEZ-QUILES, N. et al. Erk/Src phosphorylation of cortactin acts as a switch on-switch off mechanism that controls its ability to activate N-WASP. Mol. Cell Biol., v. 24, n. 12, p. 5269-5280, 2004.

MAZZONE, M. et al. Intracellular processing and activation of membrane type 1 matrix metalloprotease depends on its partitioning into lipid domains. J. Cell Sci., v. 117, pt. 26, p. 6275-6287, 2004. 
MCNIVEN, M. A. et al. The role of dynamin in the assembly and function of podosomes and invadopodia. Front. Biosci., v. 9, p. 1944-1953, 2004.

MERCURIO, A. M. Laminin receptors: achieving specificity through cooperation. Trends Cell Biol., v. 5, n. 11, p. 419-423, 1995.

MINER, J. H.; YURCHENCO, P. D. Laminin functions in tissue morphogenesis. Annu. Rev. Cell Dev. Biol., v. 20, p. 255-284, 2004.

MOCHIZUKI, M. et al. Laminin-1 peptide-conjugated chitosan membranes as a novel approach for cell engineering. Faseb J., v. 17, n. 8, p. 875-877, 2003.

MOCHIZUKI, M. et al. Angiogenic activity of syndecan-binding laminin peptide AG73 (RKRLQVQLSIRT). Arch. Biochem. Biophys., v. 459, n. 2, p. 249-255, 2007.

MONSKY, W. L. et al. Binding and localization of $M(r) 72,000$ matrix metalloproteinase at cell surface invadopodia. Cancer Res., v. 53, n. 13, p. 3159-3164, 1993.

MONSKY, W. L. et al. A potential marker protease of invasiveness, seprase, is localized on invadopodia of human malignant melanoma cells. Cancer Res., v. 54, n. 21, p. 5702-5710, 1994.

MORAIS FREITAS, V. et al. Malignancy-related $67 \mathrm{kDa}$ laminin receptor in adenoid cystic carcinoma. Effect on migration and beta-catenin expression. Oral Oncol., v. 43, n. 10, p. 987-998, 2007.

MOTT, J. D.; WERB, Z. Regulation of matrix biology by matrix metalloproteinases. Curr. Opin. Cell Biol., v. 16, n. 5, p. 558-564, 2004.

MOULD, A. P.; HUMPHRIES, M. J. Regulation of integrin function through conformational complexity: not simply a knee-jerk reaction? Curr. Opin. Cell Biol., v. 16, n. 5, p. 544-551, 2004.

MUELLER, S. C. et al. A novel protease-docking function of integrin at invadopodia. J. Biol. Chem., v. 274, n. 35, p. 24947-24952, 1999.

MYLIUS, E. A. The identification and the role of the myoepithelial cell in salivary gland tumours. Acta Pathol. Microbiol. Scand. Suppl., v. 50, p. 1-81, 1960.

NAKAGAWA, T. et al. Proteomic profiling of primary breast cancer predicts axillary lymph node metastasis. Cancer Res., v. 66, n. 24, p. 11825-11830, 2006.

NAKAHARA, $\mathrm{H}$. et al. Transmembrane/cytoplasmic domain-mediated membrane type 1matrix metalloprotease docking to invadopodia is required for cell invasion. Proc. Natl. Acad. Sci. U. S. A., v. 94, n. 15, p. 7959-7964, 1997.

NAKAHARA, $\mathrm{H}$. et al. Involvement of Cdc42 and Rac small $\mathrm{G}$ proteins in invadopodia formation of RPMI7951 cells. Genes Cells, v. 8, n. 12, p. 1019-1027, 2003.

NASCIMENTO, C. F. et al. Role of MMP9 on invadopodia formation in cells from adenoid cystic carcinoma. Study by laser scanning confocal microscopy. Microsc. Res. Tech., v. 73, n. 2, p. 99-108, 2009.

NEVILLE, B. W. et al. Patologia de Glândulas Salivares. In: NEVILLE, B. W. et al. (Ed.). Patologia Oral \& Maxilofacial. Rio de Janeiro: Guanabara Koogan, 2004. p. 314-352 
NOMIZU, M. et al. Identification of cell binding sites in the laminin alpha 1 chain carboxylterminal globular domain by systematic screening of synthetic peptides. J. Biol. Chem., v. 270, n. 35, p. 20583-20590, 1995.

NOMIZU, M. et al. Cell binding sequences in mouse laminin alpha1 chain. J. Biol. Chem., v. 273, n. 49, p. 32491-32499, 1998.

NOMIZU, M. et al. Cell adhesive sequences in mouse laminin beta1 chain. Arch. Biochem. Biophys., v. 378, n. 2, p. 311-320, 2000.

NOMIZU, M. et al. Identification of cell binding sequences in mouse laminin gamma1 chain by systematic peptide screening. J. Biol. Chem., v. 272, n. 51, p. 32198-32205, 1997.

NOMIZU, M. et al. The all-D-configuration segment containing the IKVAV sequence of laminin A chain has similar activities to the all-L-peptide in vitro and in vivo. J. Biol. Chem., v. 267 , n. 20 , p. $14118-14121,1992$.

NOMIZU, M. et al. Identification of homologous biologically active sites on the N-terminal domain of laminin alpha chains. Biochemistry, v. 40, n. 50, p. 15310-15317, 2001.

O'CONNOR, K. L. et al. RhoA function in lamellae formation and migration is regulated by the alpha6beta4 integrin and cAMP metabolism. J. Cell Biol., v. 148, n. 2, p. 253-258, 2000.

OIKAWA, Y. et al. Melanoma cells produce multiple laminin isoforms and strongly migrate on alpha5 laminin(s) via several integrin receptors. Exp. Cell Res., v. 317, n. 8, p. 1119-1133, 2010.

OLIVEIRA, E. C. Laminina-1 e seu peptídeo AG73 regulando a morfologia e atividade proteolítica de linhagem celular derivada de mioepitelioma humano. 2004. $78 \mathrm{f}$. Dissertação (Mestrado em Biologia Celular e Tecidual) - Instituto de Ciências Biomédicas, Universidade de São Paulo, São Paulo, 2004.

ORGANIZAÇÃO MUNDIAL DA SAÚDE. The Global Burden of Disease. Paris: larc Press. 2008. 146 p.

OSER, M. et al. Cortactin regulates cofilin and N-WASp activities to control the stages of invadopodium assembly and maturation. J. Cell Biol., v. 186, n. 4, p. 571-587, 2009.

OVERALL, C. M.; DEAN, R. A. Degradomics: systems biology of the protease web. Pleiotropic roles of MMPs in cancer. Cancer Metastasis Rev., v. 25, n. 1, p. 69-75, 2006.

PANTEL, K.; BRAKENHOFF, R. H. Dissecting the metastatic cascade. Nat. Rev. Cancer, v. 4, n. 6, p. 448-456, 2004.

PATARROYO, M. et al. Laminin isoforms in tumor invasion, angiogenesis and metastasis. Semin. Cancer Biol., v. 12, n. 3, p. 197-207, 2002.

PATEL, A. S. et al. Overexpression of EMS1/cortactin in NIH3T3 fibroblasts causes increased cell motility and invasion in vitro. Oncogene, v. 16, n. 25, p. 3227-3232, 1998.

PATEL, V. et al. Laminin-gamma2 overexpression in head-and-neck squamous cell carcinoma. Int. J. Cancer, v. 99, n. 4, p. 583-588, 2002. 
PEREIRA, A. L. et al. The role of matrix extracellular proteins and metalloproteinases in head and neck carcinomas: an updated review. Braz. J. Otorhinolaryngol., v. 71, n. 1, p. 81-86, 2005.

PICHOT, C. S. et al. Cdc42-interacting protein 4 promotes breast cancer cell invasion and formation of invadopodia through activation of N-WASp. Cancer Res., v. 70, n. 21, p. 83478356, 2010.

PONCE, M. L. et al. Identification of a potent peptide antagonist to an active laminin-1 sequence that blocks angiogenesis and tumor growth. Cancer Res, v. 63, n. 16, p. 50605064, 2003.

PONCE, M. L.; KLEINMAN, H. K. Identification of redundant angiogenic sites in laminin alpha1 and gamma1 chains. Exp. Cell Res., v. 285, n. 2, p. 189-195, 2003.

PONCE, M. L. et al. Identification of endothelial cell binding sites on the laminin gamma 1 chain. Circ. Res., v. 84, n. 6, p. 688-694, 1999.

PONCE, M. L. et al. An angiogenic laminin site and its antagonist bind through the alpha(v)beta3 and alpha5beta1 integrins. Faseb J., v. 15, n. 8, p. 1389-97, 2001.

POWELL, S. K.; KLEINMAN, H. K. Neuronal laminins and their cellular receptors. Int. J. Biochem. Cell Biol., v. 29, n. 3, p. 401-414, 1997.

PRICE, L. S. et al. Activation of Rac and Cdc42 by integrins mediates cell spreading. Mol. Biol. Cell, v. 9, n. 7, p. 1863-1871, 1998.

RAFII, S.; LYDEN, D. S100 chemokines mediate bookmarking of premetastatic niches. Nat. Cell Biol., v. 8, n. 12, p. 1321-1323, 2006.

RAITZ, R. et al. A study of the extracellular matrix in salivary gland tumors. J. Oral Pathol. Med., v. 32, n. 5, p. 290-296, 2003.

REGEZI, J. A.; BATSAKIS, J. G. Histogenesis of salivary gland neoplasms. Otolaryngol. Clin. North. Am., v. 10, n. 2, p. 297-307, 1977.

RENEHAN, A. G. et al. Clinico-pathological and treatment-related factors influencing survival in parotid cancer. Br. J. Cancer, v. 80, n. 8, p. 1296-1300, 1999.

RIALAS, C. M. et al. Nitric oxide mediates laminin-induced neurite outgrowth in PC12 cells. Exp. Cell Res., v. 260, n. 2, p. 268-276, 2000.

RICHARD, B. L. et al. Identification of synthetic peptides derived from laminin alpha1 and alpha2 chains with cell type specificity for neurite outgrowth. Exp. Cell Res., v. 228, n. 1, p. 98-105, 1996.

ROTHSCHILD, B. L. et al. Cortactin overexpression regulates actin-related protein 2/3 complex activity, motility, and invasion in carcinomas with chromosome 11 q13 amplification. Cancer Res., v. 66, n. 16, p. 8017-8025, 2006.

SABEH, F. et al. Tumor cell traffic through the extracellular matrix is controlled by the membrane-anchored collagenase MT1-MMP. J. Cell Biol., v. 167, n. 4, p. 769-781, 2004.

SAKU, T. et al. Immunolocalization of basement membrane molecules in the stroma of salivary gland pleomorphic adenoma. J. Oral Pathol. Med., v. 19, n. 5, p. 208-214, 1990. 
SALTEL, F. et al. Apatite-mediated actin dynamics in resorbing osteoclasts. Mol. Biol. Cell, v. 15, n. 12, p. 5231-5241, 2004.

SASAKI, T. et al. Laminin: the crux of basement membrane assembly. J. Cell Biol., v. 164, n. 7, p. 959-963, 2004.

SCHENK, S.; QUARANTA, V. Tales from the crypt[ic] sites of the extracellular matrix. Trends Cell Biol, v. 13, n. 7, p. 366-375, 2003.

SCHLAEPFER, D. D. et al. Integrin-mediated signal transduction linked to Ras pathway by GRB2 binding to focal adhesion kinase. Nature, v. 372, n. 6508, p. 786-791, 1994.

SCHLUNCK, G. et al. Modulation of Rac localization and function by dynamin. Mol. Biol. Cell, v. 15, n. 1, p. 256-267, 2004.

SCHUURING, E. The involvement of the chromosome $11 q 13$ region in human malignancies: cyclin D1 and EMS1 are two new candidate oncogenes--a review. Gene, v. 159, n. 1, p. 8396, 1995.

SEALS, D. F. et al. The adaptor protein Tks5/Fish is required for podosome formation and function, and for the protease-driven invasion of cancer cells. Cancer Cell, v. 7, n. 2, p. 155165, 2005.

SEIFERT, G.; SOBIN, L. H. The World Health Organization's Histological Classification of Salivary Gland Tumors. A commentary on the second edition. Cancer, v. 70, n. 2, p. 379385, 1992.

SHIRASUNA, K. et al. A neoplastic epithelial duct cell line established from an irradiated human salivary gland. Cancer, v. 48, n. 3, p. 745-752, 1981.

SIMPSON, J. R. et al. Adenoid cystic salivary gland carcinoma: treatment with irradiation and surgery. Radiology, v. 151, n. 2, p. 509-512, 1984.

SIQUEIRA, A. S. et al. Laminin-derived peptide AG73 regulates migration, invasion, and protease activity of human oral squamous cell carcinoma cells through syndecan- 1 and beta1 integrin. Tumour Biol., v. 31, n. 1, p. 46-58, 2010.

SKUBITZ, A. P. et al. Definition of a sequence, RYVVLPR, within laminin peptide F-9 that mediates metastatic fibrosarcoma cell adhesion and spreading. Cancer Res., v. 50, n. 23, p. 7612-7622, 1990.

SONG, S. Y. et al. Liver metastasis formation by laminin-1 peptide (LQVQLSIR)-adhesion selected B16-F10 melanoma cells. Int. J. Cancer, v. 71, n. 3, p. 436-441, 1997.

SPIRO, R. H. et al. Adenoid cystic carcinoma: factors influencing survival. Am. J. Surg., v. 138, n. 4, p. 579-583, 1979.

STERNLICHT, M. D.; WERB, Z. How matrix metalloproteinases regulate cell behavior. Annu. Rev. Cell Dev. Biol., v. 17, p. 463-516, 2001.

STRONGIN, A. Y. et al. Mechanism of cell surface activation of 72-kDa type IV collagenase. Isolation of the activated form of the membrane metalloprotease. J. Biol. Chem., v. 270, n. 10, p. 5331-5338, 1995. 
STYLLI, S. S. et al. Invadopodia: at the cutting edge of tumour invasion. J. Clin. Neurosci., v. 15, n. 7, p. 725-737, 2008.

SUBHASHRAJ, K. Salivary gland tumors: a single institution experience in India. Br. J. Oral Maxillofac. Surg., v. 46, n. 8, p. 635-638, 2008.

SUENAGA, N. et al. CD44 binding through the hemopexin-like domain is critical for its shedding by membrane-type 1 matrix metalloproteinase. Oncogene, v. 24 , n. 5 , p. 859-868, 2005.

SUZUKI, N. et al. Biological activities of homologous loop regions in the laminin alpha chain G domains. J. Biol. Chem., v. 278, n. 46, p. 45697-45705, 2003.

SUZUKI, N. et al. Functional sites in the laminin alpha chains. Connect. Tissue Res., v. 46, n. 3, p. 142-152, 2005.

TAGUE, S. E. et al. ADP-ribosylation factor 6 regulates tumor cell invasion through the activation of the MEK/ERK signaling pathway. Proc. Natl. Acad. Sci. U. S. A., v. 101, n. 26, p. 9671-9676, 2004.

TAKAI, Y. et al. Rho as a regulator of the cytoskeleton. Trends Biochem. Sci., v. 20, n. 6, p. 227-231, 1995.

TANZER, M. L. Current concepts of extracellular matrix. J. Orthop. Sci., v. 11, n. 3, p. 326331. 2006.

TARONE, G. et al. Rous sarcoma virus-transformed fibroblasts adhere primarily at discrete protrusions of the ventral membrane called podosomes. Exp. Cell Res., v. 159, n. 1, p. 141157, 1985.

TASHIRO, K. et al. A synthetic peptide containing the IKVAV sequence from the A chain of laminin mediates cell attachment, migration, and neurite outgrowth. J. Biol. Chem., v. 264, n. 27, p. 16174-16182, 1989.

TERRANOVA, V. P. et al. Modulation of the metastatic activity of melanoma cells by laminin and fibronectin. Science, v. 226, n. 4677, p. 982-985, 1984.

THIERY, J. P.; SLEEMAN, J. P. Complex networks orchestrate epithelial-mesenchymal transitions. Nat. Rev. Mol. Cell Biol., v. 7, n. 2, p. 131-142, 2006.

THOMPSON, L. World Health Organization classification of tumours: pathology and genetics of head and neck tumours. Ear Nose Throat J., v. 85, n. 2, p. 74, 2006.

TIMPL, R.; BROWN, J. C. The laminins. Matrix Biol., v. 14, n. 4, p. 275-281, 1994.

TIMPL, R. et al. Laminin--a glycoprotein from basement membranes. J. Biol. Chem., v. 254, n. 19, p. 9933-9937, 1979.

TUNGGAL, L. et al. Defective laminin 5 processing in cylindroma cells. Am. J. Pathol., v. 160, n. 2, p. 459-468, 2002.

UENO, $\mathrm{H}$. et al. Expression and tissue localization of membrane-types 1, 2, and 3 matrix metalloproteinases in human invasive breast carcinomas. Cancer Res., v. 57, n. 10, p. 20552060, 1997. 
VAN DER WAL, J. E. et al. Intraoral adenoid cystic carcinoma. The presence of perineural spread in relation to site, size, local extension, and metastatic spread in 22 cases. Cancer, v. 66, n. 9, p. 2031-2033, 1990.

VARON, C. et al. Transforming growth factor beta induces rosettes of podosomes in primary aortic endothelial cells. Mol. Cell Biol., v. 26, n. 9, p. 3582-3594, 2006.

VIRTANEN, I. et al. Laminin alpha1-chain shows a restricted distribution in epithelial basement membranes of fetal and adult human tissues. Exp. Cell Res., v. 257, n. 2, p. 298309, 2000.

VISSE, R.; NAGASE, $H$. Matrix metalloproteinases and tissue inhibitors of metalloproteinases: structure, function, and biochemistry. Circ. Res., v. 92, n. 8, p. 827-839, 2003.

WAHLBERG, P. et al. Carcinoma of the parotid and submandibular glands--a study of survival in 2465 patients. Oral Oncol., v. 38, n. 7, p. 706-713, 2002.

WANG, W. et al. Tumor cells caught in the act of invading: their strategy for enhanced cell motility. Trends Cell Biol., v. 15, n. 3, p. 138-145, 2005.

WEAVER, A. M. Invadopodia: specialized cell structures for cancer invasion. Clin. Exp. Metastasis, v. 23, n. 2, p. 97-105, 2006.

WEAVER, A. M. et al. Cortactin promotes and stabilizes Arp2/3-induced actin filament network formation. Curr. Biol., v. 11, n. 5, p. 370-374, 2001.

WEBB, B. A. et al. Cortactin regulates podosome formation: roles of the protein interaction domains. Exp. Cell Res., v. 312, n. 6, p. 760-769, 2006.

WEBB, B. A. et al. Dissecting the functional domain requirements of cortactin in invadopodia formation. Eur. J. Cell Biol., v. 86, n. 4, p. 189-206, 2007.

WEED, S. A.; PARSONS, J. T. Cortactin: coupling membrane dynamics to cortical actin assembly. Oncogene, v. 20, n. 44, p. 6418-6434, 2001.

WEEKS, B. S. et al. Laminin-1 and the RKRLQVQLSIRT laminin-1 alpha1 globular domain peptide stimulate matrix metalloproteinase secretion by PC12 cells. Exp. Cell Res., v. 243, n. 2, p. 375-382, 1998.

WEEKS, B. S. et al. The role of protein kinase $C$ in laminin-mediated neurite outgrowth. Biochem. Biophys. Res. Commun., v. 256, n. 1, p. 98-103, 1999.

WERNERT, N. The multiple roles of tumour stroma. Virchows Arch., v. 430, n. 6, p. 433443, 1997.

WILSON, D. F. et al. Oral cancer: role of the basement membrane in invasion. Aust. Dent. J., v. 44, n. 2, p. 93-97, 1999.

WISEMAN, S. M. et al. Adenoid cystic carcinoma of the paranasal sinuses or nasal cavity: a 40-year review of 35 cases. Ear Nose Throat J., v. 81, n. 8, p. 510-514, 516-7, 2002.

WU, H.; PARSONS, J. T. Cortactin, an 80/85-kilodalton pp60src substrate, is a filamentous actin-binding protein enriched in the cell cortex. J. Cell Biol., v. 120, n. 6, p. 1417-1426, 1993. 
YAMAGUCHI, $\mathrm{H}$. et al. Molecular mechanisms of invadopodium formation: the role of the $\mathrm{N}$ WASP-Arp2/3 complex pathway and cofilin. J. Cell Biol., v. 168, n. 3, p. 441-452, 2005.

YAMAGUCHI, H. et al. Invadopodia and podosomes in tumor invasion. Eur. J. Cell Biol., v. 85, n. 3-4, p. 213-218, 2006.

YANA, I.; WEISS, S. J. Regulation of membrane type-1 matrix metalloproteinase activation by proprotein convertases. Mol. Biol. Cell, v. 11, n. 7, p. 2387-2401, 2000.

YILMAZ, M.; CHRISTOFORI, G. EMT, the cytoskeleton, and cancer cell invasion. Cancer Metastasis Rev., v. 28, n. 1-2, p. 15-33, 2009.

YOSHIDA, Y. et al. Role of laminin in ovarian cancer tumor growth and metastasis via regulation of Mdm2 and Bcl-2 expression. Int. J. Oncol., v. 18, n. 5, p. 913-921, 2001.

YURCHENCO, P. D. et al. Basement membrane assembly, stability and activities observed through a developmental lens. Matrix Biol., v. 22, n. 7, p. 521-538, 2004.

YURCHENCO, P. D.; WADSWORTH, W. G. Assembly and tissue functions of early embryonic laminins and netrins. Curr. Opin. Cell Biol., v. 16, n. 5, p. 572-579, 2004.

ZHU, X.; ASSOIAN, R. K. Integrin-dependent activation of MAP kinase: a link to shapedependent cell proliferation. Mol. Biol. Cell, v. 6, n. 3, p. 273-282, 1995.

ZIOBER, A. F. et al. The extracellular matrix in oral squamous cell carcinoma: friend or foe? Head Neck, v. 28, n. 8, p. 740-749, 2006. 